\title{
RAFAEL PEPINELI
}

Avaliação do potencial papel imunomodulador

de células-tronco mesenquimais derivadas de tecido adiposo, no modelo experimental de transplante renal em ratos

Tese apresentada à Faculdade de Medicina da Universidade de São Paulo para obtenção do título de Doutor em Ciência

Programa de Nefrologia

Orientadora: Prof $\stackrel{\text { a }}{\text {. Dr }}$. Irene de Lourdes Noronha

São Paulo

2017 


\section{Dados Internacionais de Catalogação na Publicação (CIP)}

Preparada pela Biblioteca da

Faculdade de Medicina da Universidade de Săo Paulo

Creprodução autorizada pelo autor

Pepineli, Rafael

Avaliação do potencial papel imunomodulador de células-tronco mesenquimais derivadas de tecido adiposo, no modelo experimental de transplante renal em ratos / Rafael Pepineli. -- Săo Paulo, 2017.

Tese (doutorado)--Faculdade de Medicina da Universidade de São Paulo.

Programa de Nefrologia.

Orientadora: Irene de Lourdes Noronha.

Descritores: 1.Transplante de rim 2.Célulastronco 3. Tecido adiposo 4. Rejeição de enxerto 5. Fibrose 6. Imunologia de transplantes 7. Ratos endogâmicos Lew 8. Ratos endogâmicos F344

$\mathrm{USP} / \mathrm{FM} / \mathrm{DBD}-457 / 17$ 
Este trabalho foi desenvolvido no Laboratório de Nefrologia Celular, Genética e Molecular - Laboratório de Investigação Médica 29, da Faculdade de Medicina da Universidade de São Paulo (FMUSP) e recebeu apoio financeiro da Coordenação de Aperfeiçoamento de Pessoal de Nível Superior (CAPES). 


\section{QDedicatória}

OA mulher da minha vida Pamela MPlani Oepineli pelo apoia incondicional e pela seu amos principalmente nos momentos de incerteza. Obrigada pas compreender pacientemente minha ausência durante este trabalho. Sem diuvida vacê me deu forsas pasa conchive essa josnada.

Aros meus pais OPaula e Rita e que sãa um excempla de vida e familia sempre me danda forsas e me apoiando em todos os prajetos que inicia. Ofeur amox incondicional me deus esperansa nos momentos de affisãa.

Ass minhas irmäs Frernanda e Paula que entenderam e aceitaram minha auséncia em todos os eventos efestas. Qhua alegria e vontade de viver me deram motiva para nãa desistix. 


\section{Agradecimentos}

À Professora Irene de Lourdes Noronha, por ter me oferecido essa oportunidade profissional. Por ter confiado em minha palavra e por ter me apoiado em minha decisão de iniciar o transplante renal experimental. Agradeço por me passar um pouco de sua experiência na pesquisa, que sem dúvida fez a diferença nos desfechos desta tese. Aprendi muito apenas de observar suas ações no decorrer da vivência em laboratório e nas reuniões de grupo. Sinto-me honrado de ter convivido com a grande médica e pesquisadora que a Senhora é. Muito obrigado pelo apoio, oportunidade e confiança que jamais serão esquecidos!

A Dra ${ }^{a}$ Samirah A. Gomes. Sempre solícita me forneceu ajuda e experiência necessária para seguir neste trabalho. Uma profissional que admiro e tenho como exemplo. Muito obrigado.

Ao Dro Filipe Miranda mais que um amigo, um irmão que em todos esses anos me ajudou a passar por altos e baixos da vida acadêmica. Muitos churrascos serão necessários para conseguir pagar essa dívida. Muito obrigado

Ao Alexandre C. Santana, um amigo excelente que me fez dar muitas risadas durante e depois do doutorado, alguém que quero ter como amigo por muitos e muitos anos. PS: ainda vamos conseguir marcar aquele café.

A Renata Baida, professora exemplar de Biomol, que me inspira e me faz querer ser um profissional tão bom quanto se pode ser. Sempre atenciosa e solícita me fez entender que a vida de pesquisador biomédico é mais que apenas aprender, é se dedicar de corpo e alma para que tudo valha a pena ao fim.

Ao Adriano Pereira que me ensinou desde cedo na vida acadêmica a como ser um bom biomédico; dedicado e atencioso me forneceu a coragem para seguir em frente. Muito obrigado

À Cleonice Silva, uma amiga que tenho muito carinho, me deu broncas e um ombro amigo, e falou o que precisava ouvir nos momentos de dificuldade, jamais hesitou em me ajudar em tudo o que precisei, sua forma de agir e pensar me inspira a ser uma pessoa melhor. O meu mais sincero obrigado.

A Priscila Q. Gouveia, uma pessoa que tenho um carinho imenso, capaz de me fazer dar muitas risadas nos momentos mais diversos, atenciosa, dedicada e uma excelente profissional, uma amiga que me inspira e me ajudou muito neste trabalho. Sem dúvida esta tese não existiria se não fosse por ela. Muito obrigado.

A Rita C. Cavaglieri, que me irritou por muitos anos sentada ao meu lado, mas ao mesmo tempo sempre me ajudou e me apoiou em todos os momentos. Uma amiga que do seu jeito peculiar, sabe como me fazer sorrir. Muito obrigado.

Ao Elerson Costalonga, grande médico e grande pessoa que conheci. Apesar de muito quieto e contido, me ajudou muito no decorrer desta tese, me ensinando pacientemente conceitos clínicos. 
À Thalita Prado, pelos anos de convívio. Pelo suporte e força que me deu durante todo esse tempo. E pelos momentos de descontração com suas "enquetes" pessoais. Muito obrigado.

A Marcia Ribalda, Camila Fanelli e Margoth Ramos, pelo apoio nos procedimentos experimentais, pelas risadas e pela ajuda no decorrer dos anos. Muito obrigado

As alunas de Iniciação científica que tive o prazer de acompanhar Natália C. Maffei e Gisele L. Távora, Alunas dedicadas e centradas me ajudaram muito no desenvolvimento do modelo de transplante renal. Demos realmente muitas risadas juntos.

Aos outros alunos de Iniciação Científica atuais e que passaram pelo laboratório Luiza Justini (que me ajudou a treinar meu inglês) Deise Silva, Luisa Albuquerque, Felipe, Lucas e Andreza, agradeço pela ajuda e suporte. Muito obrigado.

Aos demais colegas do LIM29, Professor Luiz Fernando Onuchic (um exemplo de profissional) Andressa, Bruno Balbo, Mirtes, agradeço pelo suporte e convívio único com todos vocês.

Aos colegas do LIM16, em especial, Prof. Roberto Zatz, Prof. Joel Heimann, Prof ${ }^{a}$ Vanda Jorgetti, Ivone, Luciena, Luzia, agradeço pela disponibiliade em ajudar sempre.

Aos colegas do LIM12, Prof. Antônio Seguro, Profa Lucia Andrade, José Manuel, Heloísa Massola, Camila, agradeço por sempre serem solícitos e prestativos comigo. Muito obrigado.

Aos amigos da Pós-graduação da Nefrologia, Damaílde, Graça, Pedro, Eliana, Kaue, agradeço por toda a ajuda com burocracia e outros assuntos que sem dúvida, foram vitais para o término deste trabalho.

A minha sogra Lourdes, que ao contrário do que o dito popular prediz, é um amor de pessoa e me ajudou demais nesses últimos anos. A minha cunhada Aline e seu marido Hugo que sempre com muito carinho me deram apoio e bons motivos para rir.

À minha família, que torceu por mim durante todos esses anos, minha madrinha Jamile, que sempre foi uma segunda mãe, ao meu padrinho José Carlos (In memorian) que foi um exemplo de padrinho, minha prima Soraya que cresceu e conviveu comigo por desde sempre e que me apoiou desde o início e ao meu primo Junior que me deu boas dicas de futebol. A todos os outros tios, tias e primos que precisaria de uma página inteira para poder citar todos os nomes. Muito obrigado.

Por fim, mas não menos importante, minhas avós Ignes e Nena (in memorian) ao qual tenho muita saudade, e lembro com carinho de momentos que marcaram minha vida. Exemplo de mães e guerreiras foram únicas e jamais esquecerei de vocês. Muito obrigado. 
"Ser um campeão não é superar o outro, mas conseguir realizar os seus talentos no nível mais alto de sua existência".

Roberto Shinyashiki

"As investigações científicas revelam novas maneiras com as quais Deus trabalha e nos trazem revelações mais profundas do totalmente desconhecido". Maria Mitchell

"O único homem que está isento de erros, é aquele que não arrisca acertar.

Albert Einstein 
Esta dissertação ou tese está de acordo com as seguintes normas, em vigor no momento desta publicação:

Referências: adaptado de International Committee of Medical Journals Editors (Vancouver).

Universidade de São Paulo. Faculdade de Medicina. Divisão de Biblioteca e Documentação. Guia de apresentação de dissertações, teses e monografias. Elaborado por Anneliese Carneiro da Cunha, Maria Julia de A. L. Freddi, Maria F. Crestana, Marinalva de Souza Aragão, Suely Campos Cardoso, Valéria Vilhena. 3a ed. São Paulo: Divisão de Biblioteca e Documentação; 2011.

Abreviaturas dos títulos dos periódicos de acordo com List of Journals Indexed in Index Medicus. 


\title{
SUMÁRIO
}

\author{
Lista de Figuras \\ Lista de Siglas \\ Lista de Símbolos \\ Resumo \\ Summary
}

1. Introdução.

1.1.Transplante renal

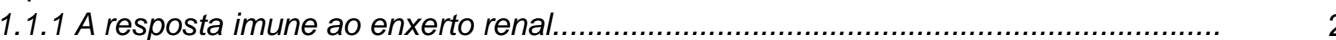

1.1.1 Complexo Principal de Histocompatibilidade.......................................................

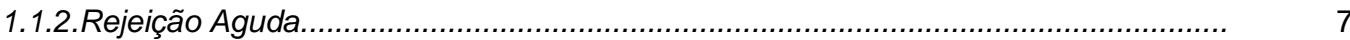

1.1.3. Rejeição Crônica...........................................................................................

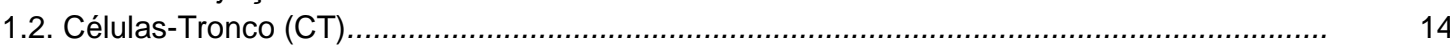

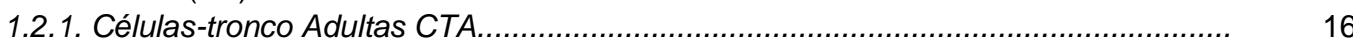

1.2.2. Células-tronco Mesenquimais de Tecido Adiposo (CTmTA)................................ 18

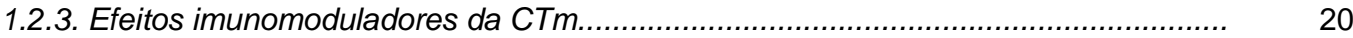

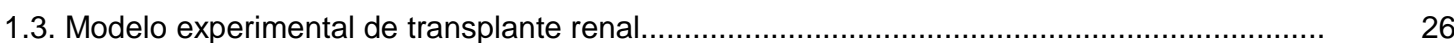

2.Objetivos

3. Materiais e Métodos

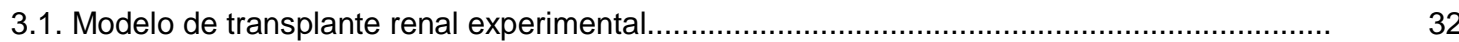

3.1.1. Animais....

3.1.2. Padronização do Modelo..............................................................................

3.1.3. A cirurgia de transplante renal experimental.................................................... 34

3.1.3. a) A cirurgia do doador..................................................................... 34

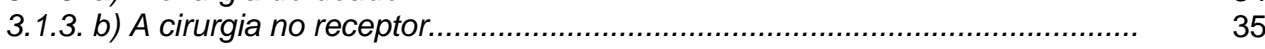

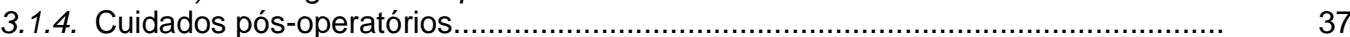

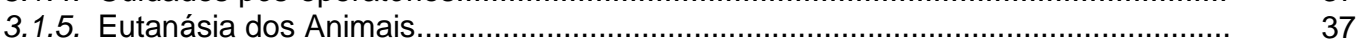

3.2. Extração de Células-Tronco de Tecido Adiposo..................................................................... 38

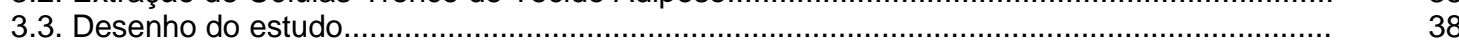

3.4. Avaliação Clínica e Bioquímica.......................................................................................... 34

3.4.1. Evolução ponderal e Peso renal..............................................................................

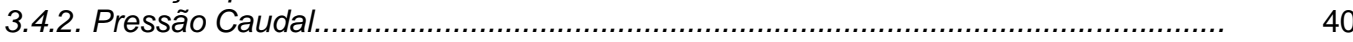

3.4.3. Análises bioquímicas....................................................................................... 40

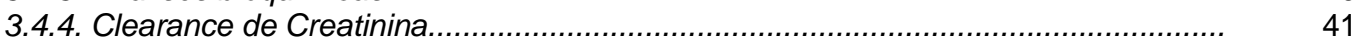

3.4.5. Fração de Excreção de sódio e potássio.................................................................

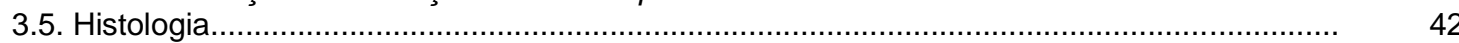

3.5.1. Coloração de Tricrômio de Masson...............................................................

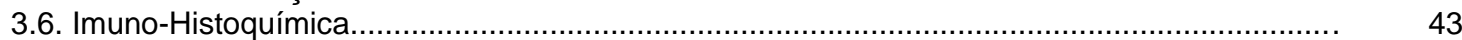

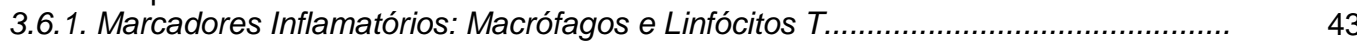

3.7. Expressão Gênica de Interleucinas pró-inflamatórias e anti-inflamatórias................................ 46

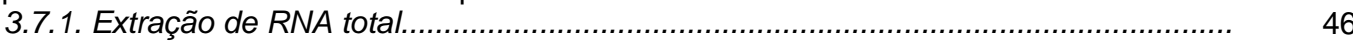

3.7.2. Quantificação do RNA total....................................................................... 47

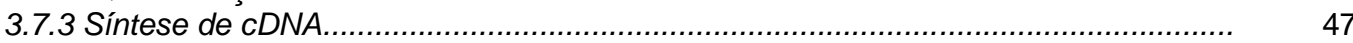

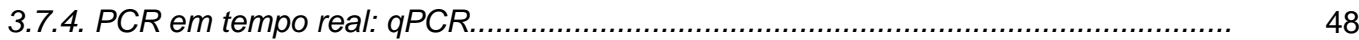

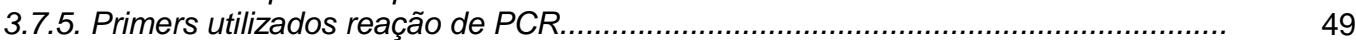

3.8. Obtenção de Células-Tronco Mesenquimais................................................................. 50

3.9.1. Extração de células de Tecido adiposo e isolamento de CTm................................

3.9.2. Método de tripsinização...............................................................................

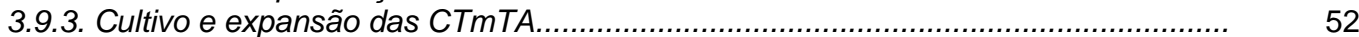

3.9.4. Caracterização das CTmTA por citometria de fluxo..............................................

3.9.5. Caracterização das CTmTA por Imunofluorescência............................................. 54

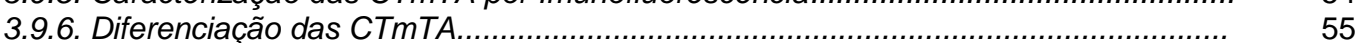

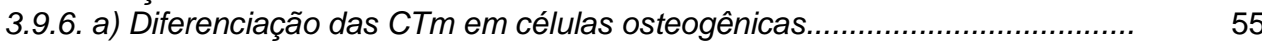

3.9.6. b) Diferenciação das CTmTA em células adipogênicas................................ 56

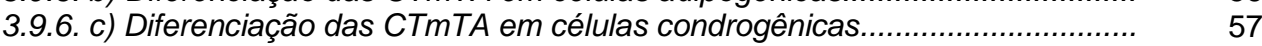

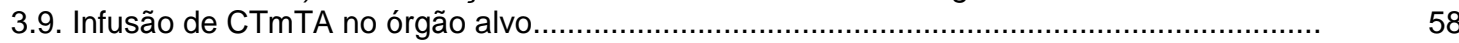

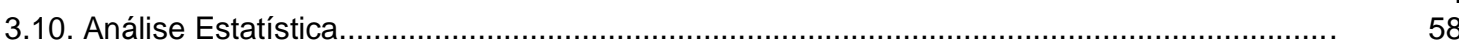

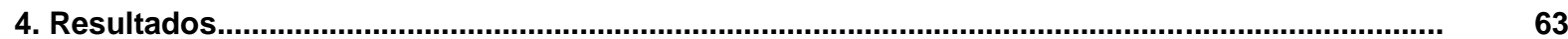

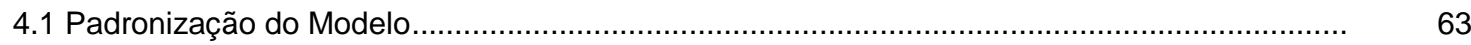

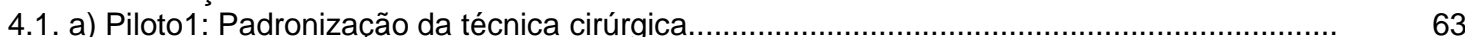

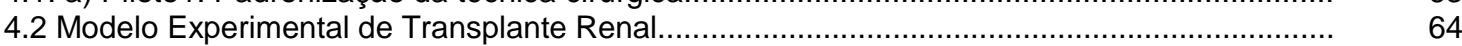




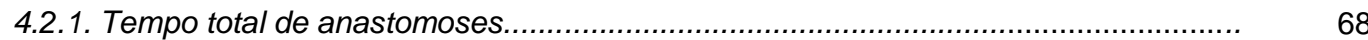

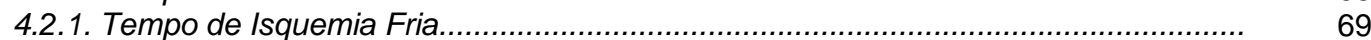

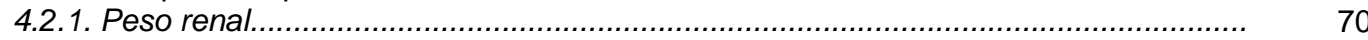

4.3 Isolamento e Cultura de CTmTA ............................................................................ 71

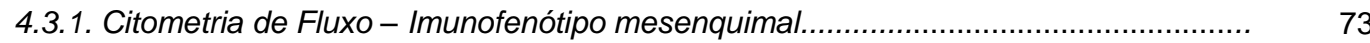

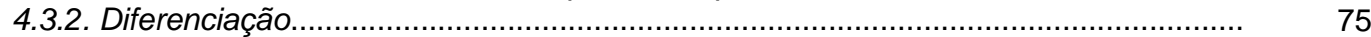

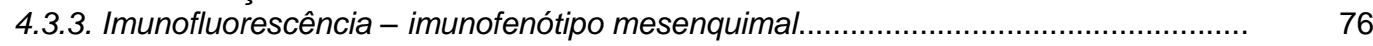

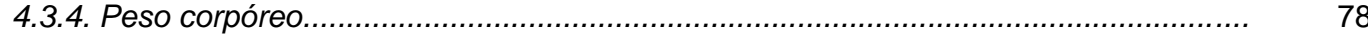

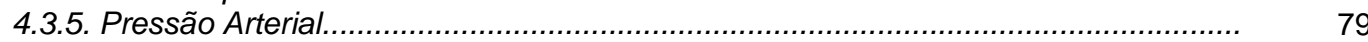

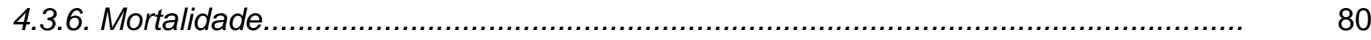

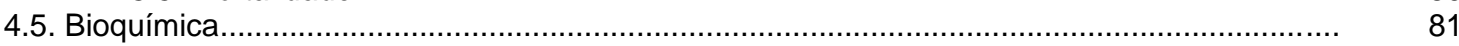

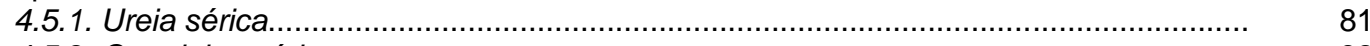

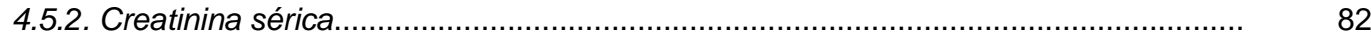

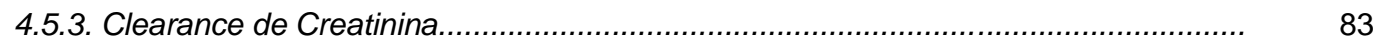

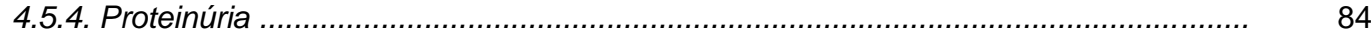

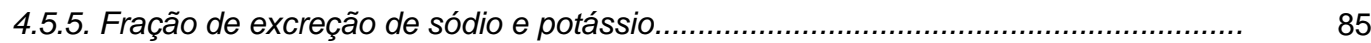

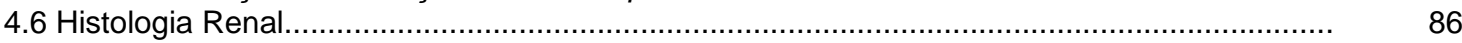

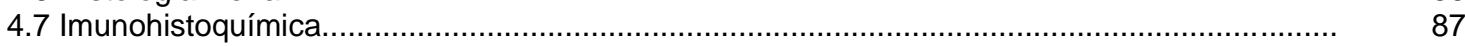

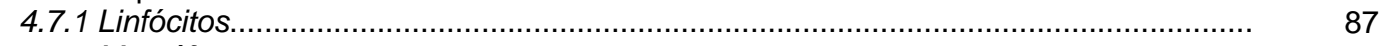

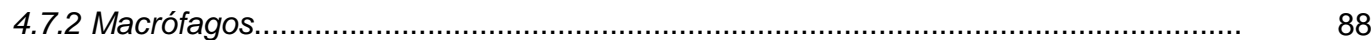

4.8. PCR em Tempo Real........................................................................................ 90

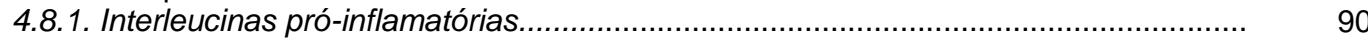

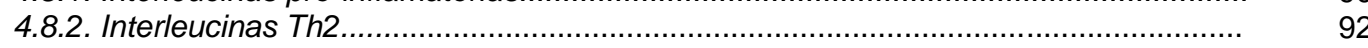

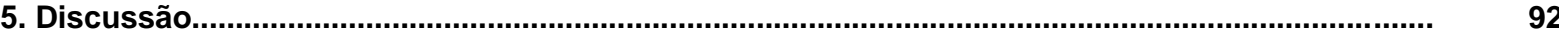

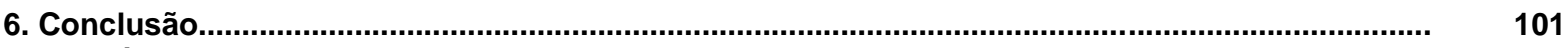

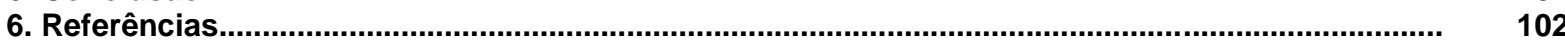




\section{Lista de figuras}

Figura 1. Estenose venosa após o reestabelecimento do fluxo sanguíneo (seta). (B) Aspecto trombótico do rim transplantado após estabelecimento do fluxo sanguíneo (seta)....64

Figura 2. Modelo experimental de transplante renal. (A) O rim do doador foi retirado, perfundido com solução fisiológica heparinizada e colocado na posição ortotópica do receptor; (B) O rim do doador foi implantado na posição ortotópica; as anastomoses foram realizadas com pontos simples equidistantes entre si; (C) O clamp vascular foi retirado e o fluxo sanguíneo restabelecido; (D) Aspecto macroscópico do enxerto renal do grupo ALO, 6 meses pós-transplante; (E) Anastomose término-terminal do ureter com pontos simples (seta). .66

Figura 3. Gráfico representativo do tempo total de anastomose nos animais receptores do transplante renal experimental....... .68

Figura 4. Gráfico representativo do tempo total de isquemia renal fria. 69

Figura 5. Gráfico representativo da média do peso renal no 6 meses pós-transplante em todos os grupos experimentais..

Figura 6. CTmTA de ratos Lewis nas passagens: (A) P0, (B) P1, (C) P4, (D) P5 e (E) P6 ......72

Figura 7: Citometria de Fluxo para fenótipo mesenquimal das CTmTA na $5^{\circ}$ passagem. Marcadores positivos CD29, CD105, CD90 e CD44 e marcadores negativos CD45 além de MHC II.

Figura 8: Diferenciação in vitro de culturas de CTmTA na 5ำ passagem. Em A) Células cultivadas em meio DMEM baixa glicose $+10 \%$ SBF; B) Células cultivadas em meio indutor adipogênico, e coradas em corante Oil Red, evidenciando o acúmulo de gotículas lipidícas; C) Células cultivadas em meio indutor osteogênico, e coradas em Vermelho de Alizarina, que mostra os depósitos de Cálcio nas células. D) Células cultivadas em meio indutor condrogênico, coradas com Safranina.

Figura 9: Imunofluorescência para marcadores positivos (CD44, CD90, CD146, CD73 e STRO1) e negativos (CD19, CD14 e CD45).

Figura 10. Gráfico representativo dos pesos corpóreo dos animais transplantados na semana 1 e nos meses 1,3 e 6 pós-transplante. ${ }^{*} p<0,05$ vs. ISO e \# $p<0,05$ vs. ALO.

Figura 11. Pressão caudal no decorrer dos 6 meses de estudos dos três grupos experimentais.

Figura 12. Sobrevida dos animais submetidos ao transplante renal durante o período de 6 meses 
Figura 13. Ureia sérica dos grupos experimentais 6 meses pós-transplante.

Figura 14. Creatinina sérica dos grupos experimentais 6 meses pós-transplante .82

Figura 15. Clearance de creatinina dos grupos experimentais 6 meses pós-transplante .83

Figura 16. Proteinúria dos grupos experimentais 6 meses pós-transplante. .84

Figura 17. Fração de Excreção de Sódio e Potássio dos grupos experimentais 6 meses póstransplante....... 85

Figura 18. Cortes histológicos corados com tricromio de Masson mostrando fibrose intersticial (azul) dos grupos experimentais 6 meses pós-transplante. .86

Figura 19. Gráfico expondo a contagem de fibrose intersticialdos grupos experimentais 6 meses pós-transplante .86

Figura 20: Determinação de linfócitos $\left(C D 3^{+}\right)$através de imuno-histoquímica. (A) ISO; (B) ALO; (C) $\mathrm{ALO}+\mathrm{CTmTA}$. 87

Figura 21: O gráfico apresenta à média referente ao número de linfócitos $\left(C D 3^{+}\right)$em cada grupo no 6 meses pós-transplante. 87

Figura 22: Determinação de Macrófagos (ED1+) através de imuno-histoquímica. (A) ISO; (B) $\mathrm{ALO} ; \mathbf{( C )} \mathrm{ALO}+\mathrm{CTmTA}$ .88

Figura 23: O gráfico apresenta a média e erro padrão referente ao número de Macrófagos $\left(\mathrm{CD}^{+} 8^{+}\right)$em cada grupo no 6 meses pós-transplante. .88

Figura 24: Expressão de TNF- $\alpha$, IL-1 $\beta, I L-6$ e INF- $\gamma$ no enxerto renal 6 meses póstransplante. . .91

Figura 25: Expressão de IL-4 e IL10 no enxerto renal 6 meses pós-transplante. .92 


\section{Lista de Tabelas}

Tabela 1: Sequência dos primers utilizados e a temperatura de melting utilizada em cada gene.

Tabela 2. Anticorpos utilizados para caracterização das células isoladas de Tecido Adiposo como CTmTA

Tabela 3. Tempo total de anastomose nos animais receptores do transplante renal experimental.....

Tabela 4. Tempo total de isquemia renal a frio durante o processo de confecção das anastomoses vasculares.

Tabela 5. Média do peso renal 6 meses pós-transplante.

Tabela 6. Porcentagem de marcação das CTmTA nas diferentes passagens

Tabela 7. Peso corpóreo dos diferentes grupos na semana 1 e nos meses 1,3 e 6 póstransplante

Tabela 8. Peso renal no momento do sacrifício, 6 meses pós-transplante. 79

Tabela 9. Ureia sérica 6 meses pós-transplante.

Tabela 10. Creatinina sérica 6 mesespós-transplante

Tabela 11. Clearance de creatinina 6 meses pós-transplante

Tabela 12. Proteinúria 6 meses pós-transplante.

Tabela 13. Fração de excreção de sódio e Potássio 6 meses pós-transplante

Tabela 14. Análise histológica do enxerto renal 6 meses pós-transplante.

Tabela 15. Expressão de citocinas pró-inflamatórias no enxerto renal 6 meses pós transplante.

Tabela 16. Expressão de citocinas anti-inflamatórias no enxerto renal 6 meses pós -transplante....... 92 


\section{Lista de Abreviaturas}

\begin{tabular}{|c|c|}
\hline ALO & Alogênco \\
\hline APC & Antigen Presenting Cells \\
\hline BSA & Albumina Sérica Bovina \\
\hline CAN & Nefropatia crônica do enxerto \\
\hline CD & Cluster Diferatiation \\
\hline cDNA & DNA complementar \\
\hline CEP & Comitê de Ética em Pesquisa \\
\hline $\mathrm{CO} 2$ & Dioxido de carbono \\
\hline $\mathrm{Cr}$ & Creatinina \\
\hline CT & Células Tronco \\
\hline CT & Cycle threshold \\
\hline CTh & Células-tronco hematopoiéticas \\
\hline CTm & Células-tronco mesenquimais \\
\hline Стмо & Células tronco de medula óssea \\
\hline CTmTA & Células tronco de tecido adiposo \\
\hline cusc & Células-tronco do cordão umbilical \\
\hline CYP 21B & Enzima 21- hidroxilase \\
\hline DAMPS & Damage-associated molecular patterns \\
\hline DAPI & 4'6-diamidino-2-phenylindole \\
\hline DMEM & Dulbecco's Modified Eagle Medium \\
\hline DNA & Ácido desoxirribonucleico \\
\hline EUA & Estados unidos da américa \\
\hline F344 & Fisher \\
\hline FITC & Fluorescein isothiocyanate \\
\hline HGMB1 & High mobility group Box-1 \\
\hline HLA & Human Leukocyte Antigen \\
\hline IDO & Indoleamina 2,3 dioxigenase \\
\hline IFN- $\gamma$ & Interferon- $\gamma$ \\
\hline IL-1 $\beta$ & Interleucina-1 $\beta$ \\
\hline IL-2 & Interleucina-2 \\
\hline IL-2R & Receptor de Interleucina-2 \\
\hline IL- & Interleucina-6 \\
\hline
\end{tabular}


ISCT International Sociaty of cellular Therapy

ISO Isogênico

K+ Potássio

LEW Lewis

LIM Laboratório de investigação médica

LSAB-AP Labeled Streptavidin-Biotin Alcaline Phosphatase

MHC Major histocompatibility complex

$\mathrm{MI} / \mathrm{min} \quad$ Mililitros/minuto

$\mathrm{Na}+\quad$ Sódio

NKF National Kidney Foundation

PAF Platelet-activating factor

$\mathrm{Pb} \quad$ Pares de bases

PBS Phosphate Buffered Saline

PCNA Atividade proliferativa

PCR Reação em cadeia da polimerase

PE Phycoeritin

PFA Paraformolaldeido

PGE2 Prostaglandina E2

PRRs Pathogen-associated pattern recognition receptors

RNA Ácido ribonucleico

RT Rat major histocompatibility complex

SFB Soro Fetal Bovino

TBS Tris buffered saline

TCR T-Cell Antigen Receptor

TGF-B Transforming growth factor beta

Th Função auxiliar

TNF- $\alpha \quad$ Tumor Necrosis Factor- $\alpha$

Tregs Células T reguladoras

Tunnel Apoptose

UC Cromatina não relacionada

USA United states of america 


\section{Lista de Símbolos}

\begin{tabular}{ll}
$\mathbf{c e ́ l} / \mathbf{m m} 2$ & Células por milímetro quadrado \\
$\mathbf{c m} 2$ & Centímetro quadrado \\
$\mathbf{d L}$ & deciLitro \\
$\Delta$ & Delta \\
$\mathbf{g}$ & Grama \\
${ }^{\circ} \mathbf{C}$ & Graus centígrados \\
$\mathbf{k g}$ & Kilogram \\
$\mathbf{L}$ & Litro \\
$\mathbf{\mu g}$ & Micrograma \\
$\boldsymbol{\mu L}$ & Microlitro \\
$\mathbf{m g}$ & Miligrama \\
$\mathbf{m g} / \mathbf{k g}$ & Miligramas/ kilogram \\
$\mathbf{m L}$ & Mililitro \\
$\mathbf{M}$ & Molar \\
$\mathbf{n M}$ & nanoMolar \\
$\mathbf{\%}$ & Porcentagem \\
$\mathbf{U} / \mathbf{m l}$ & Unidades/mililitros \\
$\mathbf{V o l}$ & Volume \\
\hline
\end{tabular}


Pepineli R. Avaliação do potencial papel imunomodulador de células-tronco mesenquimais derivadas de tecido adiposo, no modelo experimental de transplante renal em ratos [tese]. São Paulo: Faculdade de Medicina, Universidade de São Paulo; 2017.

Estudos com células tronco mesenquimais (CTm) têm despertado grande interesse devido a seu promissor potencial terapêutico e representam uma alternativa para o tratamento de diversas patologias em diferentes órgãos, inclusive em transplante renal. A rejeição crônica é um dos maiores desafios no transplante tardio e se caracteriza por perda progressiva da função renal causado pela intensa fibrogênese no aloenxerto. Os tratamentos convencionais com imunossupressores, apesar de reduzirem significativamente as crises de rejeição aguda, não interferem na sobrevida do enxerto a longo prazo. A compreensão dos processos fisiopatológicos da doença depende de seu estudo em modelos experimentais, que são de grande importância pois também propiciam uma melhor compreensão dos possíveis tratamentos. O presente estudo teve como objetivo analisar a terapia com células-tronco mesenquimais derivadas de tecido adiposo (CTmTA) no modelo experimental de transplante renal em ratos, para estudar seu efeito na rejeição crônica e avaliar seu potencial efeito imunomodulador. $\mathrm{O}$ modelo foi estabelecido com ratos das linhagens isogênicas Fisher (doador) e Lewis (receptor) e os animais transplantados foram divididos em três grupos: ISO (transplante isogênico de Lewis para Lewis, $n=6$ ), ALO (transplante alogênico de Fisher para Lewis, $n=6$ ) e ALO+CTmTA (transplante alogênico, tratado com CTmTA, $n=6$ ). As CTmTA foram caracterizadas por aderência ao plástico, diferenciação nas linhagens adipogênica, condrogênicas e osteogênicas e por citometria de fluxo. Foram inoculadas $1 \times 10^{6}$ células na região subcapsular renal no dia da realização da nefrectomia unilateral direita (10 dias pós-transplante). Após 6 meses foram realizadas análises dos parâmetros clínicos e laboratoriais, além de análise histológica, imunohistoquímica e PCR em tempo real. As CTmTA foram eficientes em prevenir significativamente a elevação da ureia e da creatinina séricas, manter clearence de creatinina em níveis normais, e prevenir a elevação da fração de excreção de $\mathrm{Na}+$ e $\mathrm{K}+$. Além disso, impediram o desenvolvimento de proteinúria e da hipertensão arterial. A análise histológica mostrou uma redução significativa do infiltrado inflamatório de macrófagos e linfócitos $T$, além de uma diminuição da fibrose intersticial no grupo ALO+CTmTA. O tratamento com CTmTA reduziu significativamente a expressão relativa dos fatores $e$ citocinas pró-inflamatórios tais como INF- $\gamma$, TNF- $\alpha$, IL1 $\beta$ e IL-6, além de aumento importante na expressão de IL-4 e IL-10, conhecidas por seu potencial antiinflamatório. Em conclusão, o tratamento com ADMSC em um modelo experimental de transplante renal pode trazer uma nova abordagem terapêutica para controle da rejeição crônica do enxerto. A aparente modulação da resposta imune observada neste trabalho, pode estar associada a uma possível polarização de macrófagos e células T. Outros estudos pré-clínicos e clínicos são necessários para confirmar nossos resultados.

Descritores: transplante de rim; células-tronco; tecido adiposo; rejeição de enxerto; fibrose; imunologia de transplantes; ratos endogâmicos Lew; ratos endogâmicos F344. 
Pepineli R. Evaluation of the potential immunomodulatory role of mesenchymal stem cells derived from adipose tissue in the experimental kidney transplant model in rats [thesis]. São Paulo: "Faculdade de Medicina, Universidade de São Paulo"; 2017.

Studies involving mesenchymal stem cells (MSCs) have aroused great interest due to their promising therapeutic potential representing an alternative for the treatment of several pathologies in different organs, including renal transplantation. Chronic rejection is one of the major challenges in late transplantation and is characterized by progressive loss of renal function caused by intense fibrogenesis in the allograft. Conventional immunosuppressive treatments, while significantly reducing acute rejection crises, do not interfere with long-term graft survival. Animal model of kidney transplantation can provide a better understanding of the pathophysiological processes and bring a new path to treat chronic rejection. The aim of this project was to analyze the therapy with mesenchymal stem cells derived from adipose tissue (ADMSCs) in the experimental model of kidney transplantation in rats, focus on chronic rejection and evaluate its potential immunomodulatory effect. The model was established with rats of isogenic strains Fisher (donor) and Lewis (recipient), and the transplanted animals were divided into three groups: ISO (isogenic transplantation from Lewis to Lewis, $n=6$ ), ALO (allogenic transplant from Fisher to Lewis, $n=6$ ) and ALO + ADMSCs (allogenic transplantation, treated with ADMSCs, $\mathrm{n}=6$ ). ADMSCs were characterized by adhesion to plastic, differentiation in adipogenic, condrogenic and osteogenic lines and by flow cytometry. One million of cells were inoculated under the renal capsule on the day of the right unilateral nephrectomy (10 days after transplantation). After 6 months, clinical and laboratory parameters were analyzed, as well as histological analysis, immunohistochemistry and real-time PCR. ADMSCs were effective in preventing elevation of serum urea and creatinine, elevation of the $\mathrm{Na}+$ and $\mathrm{K}+$ excretion fraction as well as maintained creatinine clearence at normal levels. Furthermore, the treatment also prevented the development of proteinuria and preserved blood pressure. Histological analysis showed a significant reduction of macrophages and $T$ cells infiltrate, associated to a decreased of interstitial fibrosis in the ALO + ADMSCs group. In the presence of ADMSCs, there was a significant decrease in the relative expression of INF- $\gamma$, TNF- $\alpha$, IL1 $\beta$ and IL-6 factors and pro-inflammatory cytokines, as well as a significant increase in the relative expression of anti-inflammatory cytokines as IL-4 and IL-10. In conclusion, treatment with ADMSC in a transplantation model could open a new approach to control chronic rejection. This apparent modulation of the immune response may be associated with a possible polarization of macrophages and $T$ cells. Further pre-clinical and clinical studies are needed to confirm our findings.

Descriptors: kidney transplantation; stem cells; adipose tissue; graft rejection; fibrosis; transplantation immunology; rats, inbred Lew; rats, inbred F344. 


\section{INTRODUÇÃO}

O transplante renal é reconhecido como uma das melhores alternativas de tratamento para pacientes com doença renal crônica em estágio 5. No entanto, apesar dos avanços alcançados na prática de transplante de órgãos, ancorados principalmente no aprimoramento da técnica cirúrgica, no diagnóstico precoce das complicações pós-transplante e no advento de novas drogas imunossupressoras, esta modalidade ainda apresenta limitações principalmente a longo prazo.

A rejeição é um dos maiores desafios no transplante. $O$ receptor é exposto a aloantígenos que são reconhecidos pelo sistema imunológico e estimulam uma resposta imune que pode levar à rejeição do enxerto ${ }^{1}$. Estes mecanismos imunológicos envolvidos na resposta ao aloenxerto exercem um papel patogênico importante, com impacto negativo na sobrevida do enxerto renal, levando à falência do enxerto, representando assim, um dos principais problemas para o sucesso do transplante.

O uso de novas drogas imunossupressoras que são capazes de promover uma redução significativa das crises de rejeição aguda, não interferem na sobrevida do enxerto a longo prazo². Além disso, a utilização de drogas imunossupressoras induz reações adversas, nem sempre bem toleradas pelos pacientes ${ }^{3}$. 
Assim, o desenvolvimento de novas terapias imunossupressoras e imunoreguladoras a fim de evitar a rejeição ao aloenxerto renal é de fundamental relevância.

Neste contexto, células-tronco, que são células primordiais indiferenciadas que apresentam características fundamentais de autorrenovação e de diferenciação em diferentes linhagens celulares, representam uma promissora estratégia terapêutica aplicada à medicina regenerativa e ao transplante de órgãos.

As células tronco podem, através de seus mecanismos parácrinos, promover imunomodulação, potencialmente capaz de aumentar a sobrevida dos enxertos e diminuir a necessidade de drogas imunossupressoras.

A elucidação dos mecanismos envolvidos na terapia com células-tronco em transplante é de extrema importância. Para tanto, modelos experimentais que mimetizem a situação clínica humana garantem a segurança da tradução destes conhecimentos para uma futura aplicação em ensaios de fase clínica.

\subsection{Transplante Renal}

\subsubsection{A Resposta Imune ao Enxerto Renal}

A resposta imune ao enxerto envolve a ativação do sistema imune inato e adaptativo ${ }^{4}$. Na fase inicial, imediata pós-transplante, a manipulação do órgão e 
a reperfusão do tecido são situações que causam lesão tecidual em diversos níveis. Esta agressão primária é responsável pelo desencadeamento de respostas de stress que, por sua vez, levam à expressão de diversos genes e proteínas que influenciam profundamente a reposta imune do receptor ${ }^{5,6}$. Assim, a ativação da resposta imune inata ocorre na fase inicial pós-transplante e caracteriza-se por uma reposta imune inespecífica, independente da compatibilidade genética entre doador e receptor ${ }^{7}$.

A lesão tecidual e a injúria associada ao processo de isquemia e reperfusão são capazes de gerar Damage-Associated Molecular Patterns(DAMPS), tais como radicais livres de oxigênio, heat shock proteins, high mobility group Box-1 (HGMB1), entre outros ${ }^{8,9,10}$.Os DAMPS interagem com as células do sistema imune inato através de receptores chamados Pathogen-Associated Pattern Recognition Receptors (PRRs), desencadeando uma potente resposta inflamatória que se amplifica através da geração de mediadores pró-

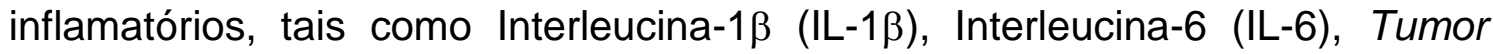
Necrosis Factor- $\alpha$ (TNF- $\alpha)$ e Interferon- $\gamma(\text { IFN- } \gamma)^{11}$. Estes eventos identificam o transplante como o local da lesão e da inflamação, levando ao aumento da permeabilidade vascular, indução de proteínas de fase aguda, que estimulam a migração de células apresentadoras de antígeno (APC - antigen presenting cells) como as células dendríticas, do enxerto para órgãos linfóides do receptor, gerando uma resposta celular através da interação do complexo principal de Histocompatibilidade (MHC: major histocompatibility complex, nos humanos chamados de HLA: Human Leukocyte Antigen) presente nas APCs com os 
receptores de células T TCR (T-Cell Antigen Receptor). Tal estímulo desencadeia a transcrição de diversos genes e síntese de fatores de crescimento, citocinas e quimiocinas levando a proliferação celular e a expansão clonal linfocitária ${ }^{12,13}$.

O papel das citocinas e quimiocinas no transplante renal como um todo é bastante complexo, alguns estudos mostram a participação tanto de mediadores relacionados com a produção de células T helper 1 (Th1) quanto de células T helper2 (Th2). Segundo Cardoni e colaboradores, na etapa de indução da resposta inflamatória do transplante renal, $\mathrm{APC}$, linfócitos $\mathrm{T}$ ativados e células natural killers (NK), na presença de IL-12, IL-18 e TNF- $\alpha$ levam ao aumento de produção de células com perfil Th1. Consequentemente, ocorre aumento da expressão de genes de CD-26 e LAG-3 (genes de ativação linfocitária), e de receptores CCR5 (receptor acoplado a proteína G que medeia a resposta de monócitos) e CXCR3 (receptor ligado a ativação e migração de linfócitos), expressos em células Th1 ativadas ${ }^{14,15}$.

Por outro lado, se houver um predomínio das citocinas IL-4, IL-10, IL-13, ocorre um aumento da produção de células Th2 e os estímulos da expressão de CD30, CD62L (cuja expressão promove recrutamento de órgãos linfoides periféricos), CCR3 (receptor de eotaxina em eosinófilos), CCR4 (receptor de TARC/CCL17, quimiocina do timo regulada por ativação), MDC/CCL22 (quimiocina derivada de macrófagos, expressa em células T, NK e células dendríticas), CCR8 (receptor de I-309/ CCL1, derivado do gene 3 de ativação celular, que é expresso em células T e neutrófilos) e CXCR4 (receptor de SDF-1a/b/CXCL12, que é um fator 
derivado do estroma expresso em células T-CD4 ativadas, células dendríticas e eosinófilos) ${ }^{14,15}$.

Outro tipo de células $T$ descritos na resposta imune aos transplantes é a célula Th17. No microambiente o fator TGF- $\beta$, em conjunto com a IL-6, induz a diferenciação de células T CD4+ numa subpopulação de linfócitos T produtores de IL-17, que apresenta um importante papel no processo inflamatório ${ }^{16}$. Essas células denominadas de Th17 expressam o fator de transcrição Related Orphan Receptor $y$ (RORYT) que inibem a indução do fator de transcrição Forkhead Box P3 (Foxp3) nas células reguladoras induzida por TGF- $\beta$ na presença de IL- $6{ }^{17}$. Essas células são inibidas pelas citocinas IFN-y, IL-2, IL-4, IL10 e IL-27, secretadas por células Th1 e Th2 e atuam como mediadoras do recrutamento de neutrófilos para os sítios de inflamação ${ }^{18,19}$.

\subsubsection{Complexo Principal de Histocompatibilidade}

O Complexo Principal de Histocompatibilidade, descrito inicialmente em 1937 por Peter Gorer durante o estudo de transplantes em ratos, é um complexo de genes com importantes funções imunológicas ${ }^{20}$. A região do $\mathrm{MHC}$ compreende genes que codificam moléculas de histocompatibilidade que são expressas na membrana celular e atuam como receptores especializados para peptídeos antigênicos ${ }^{21}$. Com isso são capazes de expor epítopos que são reconhecidos por linfócitos T, cujos receptores são específicos para reconhecer complexos de peptídeos antigênicos e moléculas $\mathrm{MHC}{ }^{21}$. 
O sistema MHC, que nos seres humanos recebe a denominação de Antígeno Leucocitário Humano (HLA - Human Leucocyte Antigen), é composto por 3 grupos de genes localizados no braço curto do cromossomo 6, chamados MHC classe I, MHC classe II e MHC classe III, sendo que apenas as classes I e II estão relacionados à apresentação de antígenos. O MHC de classe III codifica um grupo de proteínas do sistema complemento e outras estruturalmente não relacionadas às classes I e || ${ }^{22,23,24}$. A região $\mathrm{MHC}$ classe I e classe II possue 3 loci cada uma (A, B e C na região I e DP, DQ e DR na região II) que codificam glicoproteínas de membrana estruturamente similares ${ }^{22}$.

As moléculas MHC classe I são expressos em todas as células nucleadas, enquanto o MHC classe II são encontrados em tipos celulares específicos que participam da resposa imune, como linfócitos $B$, macrófagos, células dendríticas e epitélio tímico ${ }^{22}$.

As duas classes de moléculas diferem quanto ao tipo de linfócitos $T$ ao qual apresentam antígenos. Linfócitos TCD8+ respondem à antígenos associados às moléculas de classe I e linfócitos T CD4+ reconhecem aqueles ligados às proteínas MHC classe II ${ }^{22}$.

Uma característica importante do sistema MHC é seu enorme polimorfismo. Este polimorfismo pode ser constatado pelo grande número de diferentes formas alélicas para os diferentes loci de genes que codificam estas moléculas, somando mais de mil variações alélicas com produtos funcionais. Além disso, 
para cada locus há diferentes formas alternativas de genes, resultando em uma grande diversidade de proteínas ${ }^{23}$.

Considerando o enorme polimorfismo das moléculas MHC classe I e classe II e que cada variação alélica pode permitir a ligação de um grande número de peptídeos, estima-se que o potencial de apresentação antigênica na espécie tenha uma diversidade na ordem de $10^{23}$.

\subsubsection{Rejeição Aguda}

A rejeição ao aloenxerto envolve uma complexa rede de interações celulares e humorais, na qual o linfócito $\mathrm{T}$ apresenta um papel central e essencial. A resposta imune ao transplante é iniciada quando os linfócitos $\mathrm{T}$ reconhecem moléculas do MHC incompatíveis com seu próprio repertório ${ }^{25}$. O reconhecimento de aloantígenos é feito pelo TCR. Os TCR não são capazes de reconhecer antígenos livres, reconhecendo-os apenas na superfície de outras células, sejam células do doador e/ou células apresentadoras de antígeno ${ }^{26}$.

O transplante pode ser considerado uma situação ímpar, pois a ativação do linfócito T pode ocorrer por 3 vias distintas:

1. Via direta de alorreconhecimento - na qual os linfócitos $\mathrm{T}$ do receptor reconhecem alopeptídeos intactos do MHC apresentado pelas APC dos doadores;

2. Via indireta de alorreconhecimento - na qual linfócitos $\mathrm{T}$ do receptor reconhecem aloantígenos $\mathrm{MHC}$ derivados do doador que foram 
processados e apresentados (como peptídeo+MHC) na superfície celular pelas APC do receptor;

3. Via semi-direta de alorreconhecimento - através da captura do complexo peptídeo+MHC do doador pelas APC do receptor, cuja importância ainda não está clara e continua sendo investigada ${ }^{27}$.

A rejeição aguda na fase inicial pós-transplante é mediada predominantemente pela via direta de aloreconhecimento, pois o órgão transplantado trás consigo um alto número de leucócitos passageiros (que foram transferidos junto com o órgão transplantado), sendo a maioria APCs ${ }^{28}$. No entanto, à medida que os leucócitos passageiros do doador vão sendo depletados, o papel da via direta de aloreconhecimento diminui. Por outro lado, as APC do receptor continuam infiltrando o enxerto, processando e apresentando alopeptídeos solúveis do doador. Por este motivo, a longo prazo, ocorre predominância da via indireta de aloreconhecimento, mediada por linfócitos T ativados 27, 29, 30 .

Qualquer que seja a via de aloreconhecimento, a interação de aloantígenos com o TCR gera o primeiro sinal para o processo de ativação do linfócito T. No entanto, este primeiro sinal não é suficiente para ativar completamente os linfócitos T. O segundo sinal, caracterizado pela interação de moléculas coestimulatórias com seus ligantes, é fundamental para a ativação plena dos linfócitos $T^{31}$. São duas as principais famílias de moléculas co-estimulatórias: a família B7 (com seus ligantes CD28 e CD152 (CTLA-4)) e a família de receptores de TNF (representadas pelo par CD40 e CD154 (CD40L)). Quando o segundo sinal é bloqueado, os linfócitos $T$ tornam-se anérgicos e a ativação celular não 
ocorre, tornando os linfócitos $\mathrm{T}$ incapazes de prolifera ${ }^{32}$. Outro mecanismo capaz de promover a anergia dos linfócitos ocorre com a interação da molécula co-estimulatória B7 com o ligante PD-1 presente nos linfócitos T, essa interação resulta na inativação reversível dos linfócitos ${ }^{33,34 .}$

A interação dos antígenos com o TCR, no contexto das moléculas do MHC, ativa inúmeros eventos bioquímicos de sinalização intracelular, desencadeando rapidamente uma complexa cascata de ativação intracitoplasmática que leva ao rearranjo do citoesqueleto, ativação de fatores de transcrição e diferenciação celular.

A transmissão dos sinais intracelulares de ativação induz eficientemente e rapidamente o aumento da transcrição dos genes que codificam a IL-2 e outras citocinas. Concomitantemente, ocorre aumento da expressão de receptores para IL-2 (IL-2R) nos linfócitos T. Por sua vez, a interação da IL-2 com seus receptores (IL-2R) resulta no terceiro sinal de ativação linfocitária, que promove a ativação do ciclo celular e a proliferação clonal determinando o aparecimento de grande número de células efetoras ${ }^{35}$.

O resultado final de toda esta cadeia orquestrada de eventos é o agravamento da resposta inflamatória local e agressão ao aloenxerto através de diferentes vias efetoras. Após a ativação, os linfócitos T, dependendo do microambiente e de sinais adicionais, diferenciam-se em células que têm diversas capacidades funcionais. Os linfócitos CD4+ adquirem função auxiliar (Th), que apresentam 
diferentes funções de acordo com as subpopulações definidas por assinaturas de citocinas como Th1, Th2, Th17 e Th9 ${ }^{36}$.

A resposta mediada por linfócitos $\mathrm{T}$ aloantígeno-específica, participa da fase efetora da rejeição do enxerto por um mecanismo não específico definido como resposta de hipersensibilidade retardada ou tardia, caracterizada pela liberação de vários mediadores solúveis, incluindo as citocinas pró-inflamatórias como IL$1 \beta$, TNF- $\alpha$, IL-6 e IFN- $\gamma$, entre outras ${ }^{36}$. A reação de hipersensibilidade do tipo tardia afeta diretamente a fisiologia do enxerto, alterando a permeabilidade celular, desempenhando um papel importante na rejeição aguda e crônica ao aloenxerto.

As citocinas são responsáveis pela organização do processo inflamatório incluindo o recrutamento e ativação de células não específicas com produção de diversos mediadores, dentre eles, substâncias hemodinamicamente ativas como, fator de ativação plaquetarea (PAF), prostaglandinas e eicosanóides, que contribuem para a isquemia tecidual. Monócitos, linfócitos e neutrófilos também são ativados por citocinas com consequente liberação de enzimas, óxido nítrico, radicais livres de oxigênio, substâncias derivadas do ácido araquidônico (prostaglandina E2, tromboxano e leucotrienos) e fatores da coagulação que resultam em isquemia e lesão celular $37,38,39,40$.

A rejeição aguda tem consistentemente sido relatada como sendo o mais importante fator de risco que leva à insuficiência crônica do enxerto 41, 42, 43, 44, 45. Embora diversos avanços tenham sido realizados na prevenção e no tratamento 
da rejeição aguda, maximizando a sobrevivência do enxerto a curto prazo, a longo prazo, tais melhorias não apresentaram impacto positivo na a sobrevida do enxerto.

\subsubsection{Rejeição Crônica}

A rejeição crônica é a causa mais frequente de perda de função do enxerto no período tardio pós-transplante renal ${ }^{46}$. É diagnosticada pela presença de uma deterioração progressiva da função do enxerto associada a alterações morfológicas vasculares e túbulos-intersticiais ${ }^{47}$. Clinicamente, apresenta-se com aumento progressivo dos níveis de creatinina plasmática e proteinúria ${ }^{48,49}$.

A proteinúria renal por sua vez, expressa o aumento de lesões glomerulares com alteração a permeabilidade seletiva dos capilares glomerulares, levando ao aumento da filtração das proteínas plasmáticas para o filtrado glomerular ${ }^{50}$.

O desenvolvimento da rejeição crônica parece depender de três eventos principais: a lesão endotelial, a liberação de citocinas e a resposta imunológica inflamatória mediada por células e por anticorpos ${ }^{51}$.

O aloreconhecimento de células endoteliais pode resultar em um processo de inflamação dos vasos sanguíneos conhecido como vasculopatia do transplante. Atualmente, o termo "vasculopatia crônica do transplante" tem sido utilizado para definir as alterações que acometem os vasos do aloenxerto durante o processo de rejeição crônica. Tal fenômeno é caracterizado pelo espessamento progressivo e difuso da camada íntima dos vasos, processo pelo qual é 
decorrente da migração e proliferação das células da musculatura lisa vascular (vascular smooth muscle cells - VSMC) na íntima, culminando no estreitamento significativo da luz das artérias com consequente isquemia e falência do órgão transplantado ${ }^{52}$.

Diversas evidências sugerem que esse processo se inicia a partir da lesão e ativação das células endoteliais ${ }^{53}$. As células endoteliais ativadas aumentam a expressão de moléculas MHC e de moléculas de adesão, além de produzirem diversos mediadores inflamatórios, promovendo um fenômeno de inflamação local com recrutamento de linfócitos e monócitos.

Os mecanismos celulares envolvidos na vasculopatia crônica do transplante caracterizam-se pela produção de citocinas pró-inflamatórias pelas células endoteliais que podem induzir a migração de VSMC da túnica média para a túnica íntima ${ }^{54}$. De fato, alguns autores demonstraram que as citocinas inflamatórias, como TNF- $\alpha$, IL-1 $\beta$ e INF- $\gamma$ podem estimular a migração e/ou proliferação das VSMC $55,56,57$.

Recentemente foi melhor caracterizada a rejeição crônica mediada por anticorpos. A rejeição crônica mediada por anticorpo está associada à presença de anticorpos circulantes contra moléculas MHC de classe I ou classe II do doador, com a detecção de depósitos de C4d (componente do sistema complemento) nos capilares peritubulares, em aproximadamente 30 a 50\% dos casos ${ }^{58}$. A presença de depósitos $\mathrm{C} \mathrm{d}^{+}$, acúmulo de células polimorfonucleares nos capilares peritubulares e anticorpos circulantes doador específicos são 
características usadas para o diagnóstico de rejeição crônica mediada por anticorpos ${ }^{59}$.

O acometimento dos túbulos renais e o interstício renal tanto por mecanismos celulares quanto por mecanismos humorais levam ao comprometimento da arquitetura do enxerto com fibrose intersticial e atrofia tubular (FIAT). A patogênese da FIAT é provavelmente multifatorial mediada por mecanismos imunes, aloantígenos dependentes (rejeição aguda, retardo na função do enxerto, histocompatibilidade, hipersensibilização) e não imunes, aloantígenos independentes (massa de néfrons, hipertensão, imunossupressão inadequada, hiperlipidemia, má aderência às medicações, infecção pelo citomegalovírus, poliomavírus, nefrotoxicidade por ciclosporina ou tacrolimo) ${ }^{60,61}$.

A fibrose intersticial difusa é uma característica da rejeição crônica ao transplante. Ao contrário das reações inflamatórias agudas, que são caracterizadas por rápidas mudanças vasculares, edema e infiltração de células inflamatórias, a fibrose se origina geralmente de reações inflamatórias crônicas, definida como resposta que persiste por vários meses ou anos e cuja inflamação, destruição tecidual e processo de reparo ocorrem simultaneamente. Apesar de diferentes etiologias e distinções clínicas, a maioria das doenças fibróticas tem em comum uma inflamação persistente que mantém a produção de fatores de crescimento, enzimas proteolíticas, fatores angiogênicos e citocinas prófibróticas que, juntas, estimulam a deposição de elementos teciduais conjuntivos que remodelam ou destroem progressivamente a arquitetura tecidual normal ${ }^{62}$. 
Independente da causa inicial, o desenvolvimento da fibrose intersticial é caracterizado pelo aparecimento de fibroblastos ativados positivos para $\alpha$-actina de músculo liso ( $\alpha$-SMA), também denominados de miofibroblastos. No parênquima renal, a deposição de produtos da matriz extracelular é amplamente atribuída a essas células ${ }^{63}$.

Até o momento não existem tratamentos específicos para a rejeição crônica, e os medicamentos imunossupressores são ineficientes em controlar a progressão da doença, sendo assim, os pacientes apresentam geralmente perda progressiva da função do enxerto e retorno à terapia dialítica ${ }^{64}$.

\subsection{Células Tronco (CT)}

O conceito de CT surgiu a partir de experimentos pioneiros realizados no início dos anos 1960 por Ernest A. McCulloch e James E. Till que observaram a presença de colônias hematopoiéticas no baço de camundongos irradiados e que haviam recebido transplante de medula. Essas colônias eram derivadas de uma única célula, a CT ${ }^{65}$. Outros estudos, realizados nas décadas de 70 e 80 pelo grupo de pesquisa de Alexander Friedenstein ampliaram o potencial de uso das CT, demonstrando sua capacidade de autorenovação e diferenciação ${ }^{66}$. $\mathrm{Na}$ época, devido à semelhança morfológica com fibroblastos em cultura, foram denominadas unidades formadoras de colônia fibroblástica (UFC-F) ${ }^{67}$. Nas 
décadas seguintes, extensas pesquisas foram desenvolvidas para desvendar o potencial terapêutico das CT.

Por definição, CT são células capazes de autorrenovação prolongada através de sucessivas divisões mitóticas do tipo assimétrica e passíveis de originar pelo menos um tipo celular em estágio mais avançado de diferenciação ${ }^{68}$. As CT são células não especializadas, ou seja, não possuem ainda comprometimento morfológico e funcional com nenhum tipo celular ${ }^{69}$.

As CT podem ser divididas em dois grandes grupos que dizem respeito ao seu local de origem: podem ser embrionárias (CTE), quando são derivadas da massa celular interna do blastocisto embrionário; e adultas (CTA) que são aquelas localizadas em estado mais diferenciado na maioria dos tecidos do organismo adulto ${ }^{70}$. Levando em consideração o grau de plasticidade da CT, ou seja, o seu potencial de diferenciação em tecidos variados, podemos classificá-las em três tipos: totipotentes, pluripotentes e multipotentes.

As CT totipotentes podem originar tanto um organismo totalmente funcional, como qualquer tipo celular do corpo, inclusive todo o sistema nervoso central e periférico ${ }^{71}$. Correspondem às células do embrião recém-formado (zigoto) e têm potencial para originarem até mesmo as células dos folhetos extra-embrionário, que formarão a placenta e os demais anexos responsáveis pelo suporte ao embrião. Entretanto, estas células possuem um tempo de vida curto e desaparecem poucos dias após a fertilização ${ }^{72}$. 
As pluripotentes são células capazes de originar qualquer tipo de tecido sem, no entanto, originar um organismo completo, visto que não podem gerar a placenta e outros tecidos embrionários de apoio ao feto. Formam a massa celular interna do blastocisto depois do quarto dia de fecundação e participam da formação de todos os tecidos do organismo ${ }^{72}$.

As CT multipotentes são um pouco mais diferenciadas, presentes no indivíduo adulto, com capacidade de originar apenas um limitado número de tipos teciduais. Estas células são designadas de acordo com o órgão do qual derivam, e possibilitam a regeneração tecidual local ${ }^{71}$.

\subsubsection{Células Tronco Adultas (CTA)}

As CTA podem ser encontradas em vários órgãos e tecidos no indivíduo adulto, onde participam da homeostase tecidual, gerando novas células em resposta ao repovoamento celular fisiológico ou a algum tipo de injúria. Tais populações celulares indiferenciadas mantidas no organismo adulto são denominadas células-tronco adultas ou adulto-específicas ${ }^{73,74,75}$.

As CTA estão em estado quiescente ou de baixa proliferação, predominantemente nas fases G0 e G1 do ciclo celular, localizando-se em regiões específicas essenciais para o seu desenvolvimento e a manutenção de seus atributos, particularmente a capacidade de autorrenovação ${ }^{76}$. Estas regiões são denominadas de nichos celulares e dentre os principais sítios estão: medula óssea ${ }^{77}$, coração ${ }^{78}$, rins ${ }^{79}$, pele ${ }^{80}$, fígado ${ }^{81}$, pâncreas, ovários, cordão 


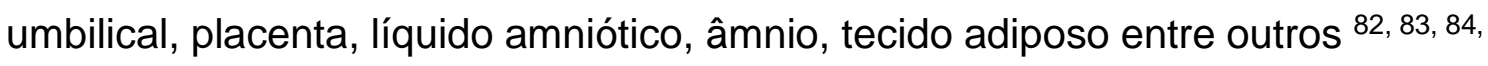
$85,86,87,88$.

As primeiras CTA estudadas e, consequentemente, as mais bem caracterizadas são as CT hematopoiéticas provenientes da medula óssea ${ }^{89}$. Anos mais tarde foi isolado outro tipo de CTA também constituinte da medula óssea, porém com características diferentes das hematopoiéticas. Devido sua origem a partir das células estromais da medula óssea, e sua possível natureza de CT, Owen e Friedenstein (1988) adotaram o termo "células tronco estromais da medula óssea". Estudos subsequentes demonstraram que essas células possuíam a capacidade de se diferenciar em linhagens celulares mesodérmicas, incluindo condrócitos, osteoblastos, adipócitos e mioblastos. Com base nessa capacidade de diferenciação em multilinhagens, Caplan, em 1991, introduziu o termo célulatronco mesenquimal (CTm) ${ }^{90}$.

Com o aumento na utilização das CTm e a ausência na uniformidade para sua caracterizaçãoo Comitê de Células Tronco Mesenquimais e Teciduais da Sociedade Internacional de Terapia Celular (SITC) propôs critérios mínimos para definir as CTm humanas. Primeiro, as CTm devem ser "aderentes ao plástico" (aderentes ao substrato), quando mantidas em condições padrão de cultivo in vitro. Segundo, as CTm devem expressar as moléculas mesenquimais de superfície CD105, CD73 e CD90, e não expressar as moléculas de superfície classicamente hematopoiéticas CD45, CD34, CD14 ou CD11b, CD79a ou CD19, e HLA-DR. Terceiro, as CTm devem se diferenciar in vitro em linhagens osteogênicas, adipogênicas e condrogênicas ${ }^{91}$. 
Tradicionalmente, as CTm foram isoladas a partir de células da medula óssea. Entretanto, elas também podem ser isoladas a partir do cordão umbilical, do tecido sinovial, do tecido adiposo e, em frequência extremamente menor, do sangue periférico de adultos ${ }^{92}$.

Nos últimos anos, as células-tronco mesenquimais de tecido adiposo (CTmTA) têm surgido como uma fonte celular bastante atrativa para fins terapêuticos, devido às vantagens em sua aquisição em comparação as células do estroma da medula óssea (CTMO). Além disso, o custo na extração de células de tecido adiposo é significativamente menor quando comparado à punção de medula óssea ${ }^{93,94}$.

\subsubsection{Células Tronco Mesenquimaisde Tecido Adiposo (CTmTA)}

Em humanos adultos, o principal depósito de tecido adiposo é conhecido como tecido adiposo branco (TAB). O TAB está presente em diversas regiões do organismo, envolvendo órgãos e estruturas internas ou mesmo infiltrando-se neles 95,96 .

O desenvolvimento do TAB em humanos tem início no segundo terço do período gestacional com a agregação de uma densa massa de células mesenquimais indiferenciadas, orquestrada com o início da organização vascular. As células desses agregados diferenciam para células adiposas primitivas, adjacentes a capilares ${ }^{97}$. Estágios mais avançados do desenvolvimento do TAB estão relacionados ao crescimento dos agregados e a maturação das células adiposas. Assim como a medula óssea, o TAB é um derivado do mesoderma 
embrionário e gera, quando colocado em cultura, uma fração celular aderente, um estroma ${ }^{98}$.

Anatomicamente, o TAB se distribui no organismo como tecido adiposo subcutâneo (TAS) e tecido adiposo visceral (TAV). Além dos adipócitos, o TAB contém uma matriz de tecido conjuntivo (fibras colágenas e reticulares), tecido nervoso, células do estroma vascular, nódulos linfáticos, células do sistema imune (leucócitos, macrófagos), fibroblastos e células-tronco 95, 96.

O TAB representa uma fonte abundante de CTmTA para transplantes autólogos. Comparativamente, as CTMO, CTmTA e as células-tronco do cordão umbilical demonstraram não apresentar diferenças quanto à morfologia e ao fenótipo imunológico 99, 100 contudo, a frequência de CTmTA no tecido adiposo excede a frequência das CTMO no estroma medular ${ }^{101}$. Além disso, a taxa de proliferação celular das CTmTA apresentou-se maior em comparação às CTMO ${ }^{102}$.

Atualmente, o interesse pelas CTmTA tem aumentado muito na medicina, principalmente em função da facilidade de obter grandes quantidades destas células pelo processo de lipoaspiração. Como o tecido adiposo humano está presente em muitas regiões, é de fácil obtenção em grandes quantidades sob anestesia local com pouco desconforto para o paciente, podendo se configurar como fonte alternativa de CT para a regeneração dos tecidos mesenquimais e engenharia de tecidos ${ }^{103}$.

Imunologicamente, Hsiao e colaboradores demonstraram, em um estudo comparativo, que as CTmTA apresentam funções imunomoduladoras 
semelhantes às CTMO, além de aparentemente apresentarem uma maior capacidade angiogênica ${ }^{104}$. Além disso, diversos outros trabalhos têm mostrado que a terapia com CTmTA pode minimizar danos renais em modelos experimentais de lesão isquêmica ${ }^{105}$, fibrose renal progressiva ${ }^{106}$, lesão renal aguda induzida por cisplatina ${ }^{107}$ ou ácido fólico ${ }^{108}$, estenose aterosclerótica da artéria renal em suínos 109, 110, 111 e em modelo de doença da membrana basal glomerular ${ }^{112}$.

Sendo assim, o uso de CTmTA, cujos efeitos imunomoduladores vem sendo cada vez mais confirmados pela literatura, constituem uma promissora estratégia de prevenção da rejeição crônica após transplante renal podendo ter impacto na inflamação local a curto e longo prazo.

\subsubsection{Efeitos imunomoduladores das CTm}

Embora existam vários estudos na literatura demonstrando o efeito imunomodulador das CTm, os mecanismos de ação pelas quais elas agem ainda precisam ser elucidados de forma mais ampla e detalhada, de modo a esclarecer com mais exatidão os papéis da sinalização por mediadores parácrinos, fusão celular, interação célula-célula, neovascularização e outros mecanismos menos conhecidos.

Diversos estudos têm demonstrado dois pontos cruciais no que se refere à relação das CTm com o sistema imune: 1) elas são consideradas imunoprivilegiadas ${ }^{113,114,93}$;2) elas parecem modular o sistema imune ${ }^{115,116,}$ 117, tendo ação direta no bloqueio das funções efetoras das células $T^{118}$, inibindo 
a proliferação e ativação de linfócitos T em experimentos de co-cultura ${ }^{114}$. Além disso, favorecem o surgimento de Tregs 115 e induzem linfócitos T CD4+, incluindo células altamente diferenciadas Th17 ${ }^{119}$, em fenótipo regulador e de função reguladora ${ }^{120}$. As CTm são capazes de bloquear a diferenciação de monócitos em células dendríticas, resultando na geração de células incapazes de estimular de modo eficiente a resposta Th1 120, 121, 122, 123.

As primeiras evidências do papel das CTm sobre o sistema imune vêm do trabalho de Bartholomew e colaboradores, que mostraram que a administração intravenosa de CTm em babuínos foi capaz de prolongar a sobrevivência de enxertos alogenêicos de pele, de forma similar a potentes drogas imunossupressoras utilizadas rotineiramente na clínica ${ }^{118}$.

Posteriormente, seu papel na regulação do sistema imune começou a ser estudado in vitro, inicialmente na função das células T. Krampera e colaboradores mostraram que as CTm diminuem a resposta de células $\mathrm{T}$ naive e de células T de memória a seus antígenos específicos, um efeito que parece ser independente de células dendríticas ${ }^{93}$. Foi também demonstrado que as CTm são capazes de atenuar a produção de IL-2 por células $T$, o que resulta na diminuição da formação de células T CD8 citotóxicas ${ }^{124}$. Essa inibição afeta a proliferação de células T induzida por aloantígenos, assim como por anticorpos para CD3 e CD28 ${ }^{125}$.

A indução de anergia das células T tem sido proposta como potencial mecanismo para o efeito imunossupressor das CTm. Os baixos níveis de expressão de 
moléculas co-estimulatórias, como CD40, CD80 e CD86, tem sido relacionado ao potencial estado de anergia das células $T$ induzido pelas $\mathrm{CTm}{ }^{125}$. Os efeitos imunomoduladores das CTm também parecem depender de vários fatores como INF- $\gamma$, TGF- $\beta$, PGE2, IL-10 e Indoleamina-pyrrole 2,3 dioxygenase (IDO). Estes fatores têm sido propostos como mediadores da supressão de linfócitos $T$, indução de macrófagos M2 e células Tregs capazes de regular a resposta imune 126,127

As células T CD4+CD25+ ou Tregs originam-se no timo e são conhecidas como células reguladoras naturais e constituem cerca de $5-10 \%$ de todas as células T do organismo. No sistema murino, exibem uma potente atividade reguladora tanto in vivo como in vitro ${ }^{128}$. As Tregs suprimem a proliferação de células TCD4+CD25- e células T CD8+, assim como a secreção de IFN-y, tanto in vitro como in vivo ${ }^{129}$. Essas células desempenham um importante papel na regulação da resposta imune através da inibiçãode células $T$ auto-reativas. Mais recentemente, foi identificada nessas células uma alta expressão do fator de transcrição chamado Foxp3 ${ }^{130}$. O Foxp3 é um fator da proteína escurfina pertencendo à família de fatores de transcrição forkhead ${ }^{131}$.

A manutenção e sobrevivência das células T CD4+CD25+ é regulada por IL-2. O uso de anticorpos anti-IL-2 anula completamente a função supressora das células CD4+CD25+, in vitro ${ }^{132}$. Esses autores também demonstraram que a neutralização de IL-2, in vivo, inibe a proliferação homeostática de células T CD4+CD25+ periféricas em animais linfopênicos. A interação da IL-2 com o seu 
receptor parece ser essencial, no timo, para promover a geração de células T reguladoras e regulação da expressão de CD25 e Foxp3 ${ }^{133}$.

As células $\mathrm{T}$ reguladoras podem atuar suprimindo a resposta imune tanto por meio de fatores solúveis como TGF- $\beta$ e IL-10 quanto por um mecanismo dependente de contato célula a célula, como mediados pelo CTLA-4 134, 135, 136. Outros mecanismos de supressão também já descritos é a geração de células T reguladoras gerenciado por células dendríticas plasmocitóides expressando IDO. Essas células T reguladoras estimulariam a expressão de PD-L em outras células dendríticas que ao se ligarem a PD-1 (Programmed Death 1), presente em células T efetoras, induziria apoptose nessa população ${ }^{137}$.

Além da ação sobre as células T, as CTm também podem atuar por outros mecanismos, como promovendo a inibição de linfócitos B. A atuação da CTm sobre os linfócitos $B$ foi pouco estudada até o momento. Corcione e colaboradores mostraram uma inibição da proliferação de células $B$, em coculturas com CTm humanas, mediante à parada do ciclo celular na fase G0/G1 . Nesse estudo, foi demonstrado também que as CTm parecem afetar as propriedades quimiotáticas das células $B$, embora não afetassem sua produção de citocinas ${ }^{138}$. Recentemente, porém, Rasmusson e colaboradores mostraram que as CTm estimulam a secreção de anticorpos por células $B$ in vitro. Dependendo do nível de estimulação das células B, as CTm podem induzir ou inibir a secreção de lgG pelas células B ${ }^{139}$. 
A relação das $\mathrm{CTm}$ com as células natural killer (NK) também tem sido investigada. Spaggiari e colaboradores mostraram que as CTm são capazes de iniber fortemente a proliferação de células NK, sua atividade citotóxica e sua produção de citocinas ${ }^{140}$. As CTm também atuam de forma importante sobre a diferenciação, maturação e função das células dendríticas ${ }^{141}$. As CTm são capazes de bloquear a diferenciação de monócitos e precursores da medula óssea em células dendríticas e inibir o aumento da expressão de moléculas coestimulatórias CD1A, CD40, CD80 CD86 e HLA-DR durante a maturação das células dendríticas, mantendo-as em um estado imaturo. Mais recentemente, foi demonstrado que as CTm induzem a expressão de IL-10, uma citocina "tolerogênica", pelas células apresentadoras de antígeno ${ }^{142}$, o que sugere que as CTm poderiam induzir um fenótipo supressor ou inibitório das células dendríticas.

Sabe-se ainda que células dendríticas imaturas podem expandir populações de células Treg ${ }^{143,144}$ e acredita-se que este processo contribuiria para a sobrevivência do enxerto. Deste modo, as CTm poderiam prevenir respostas alogênicas através da modulação das células dendríticas ou diretamente sobre as células $T^{145}$.

Em 2005, Maccario e colaboradores descreveram a capacidade das CTm humanas de induzir a diferenciação de células T CD4+ para um fenótipo supressor ou regulador ${ }^{146}$. Ainda, segundo Gonzalez-Rey a inoculação de CTmTA em camundongos com doença inflamatória intestinal, resultou em uma melhora nos scores da doença além de promover de um aumento do número de 
células CD4 + CD25 +Foxp3 + e células CD4 + IL10 + nos gânglios linfáticos, ressaltando um efeito sistêmico das CTmTA 147.

Com as descobertas recentes e favoráveis a respeito das propriedades imunomodulatórias das CTm, diversos estudos clínicos vêm sendo realizados. Ao todo, 613 estudos são encontrados na plataforma Clinical trials com a utilização de CTm para tratamento de diversas patologias. Em transplante renal, são encontrados 16 estudos, dos quais 9 estão em andamento. Esses achados sugerem que apesar do grande potencial da terapia com CTm, muitos estudos pré-clínicos ainda são necessários para esclarecer o funcionamento e a capacidade imunoreguladora das CTm.

Juntos, estes estudos in vitro e in vivo fornecem embasamento científico suficientes para a aplicação das CTm como terapia celular com intuito de modular a resposta imune adaptativa in vivo em modelos experimentais de transplante de órgãos sólidos. As ações das CTm na inibição da proliferação dos linfócitos $T$, na redução da diferenciação de monócitos em células dendríticas, na supressão dos efeitos tóxicos pelas células natural killer, na modulação da função dos linfócitos B além de seus efeitos anti-inflamatórios, podem contribuir para a prevenção da rejeição do transplante renal e um melhor resultado na sobrevida do enxerto. 


\subsection{Modelos Experimentais de Transplante Renal}

O desenvolvimento de modelos experimentais é importante na medida em que estes auxiliam na compreensão dos fenômenos naturais de difícil avaliação em seres humanos. Na ciência médica, permitem o melhor conhecimento da fisiologia, da etiopatogenia das doenças, da ação de medicamentos e dos efeitos das intervenções cirúrgicas.

O uso de modelos animais em pesquisas vem sendo realizado desde a antiguidade. Os anatomistas Alcmaeon (500 aC), Herophilus (330-250 aC) e Erasistratus (305-240 aC) realizavam vivissecções animais com o objetivo de observar estruturas e formular hipóteses sobre seu funcionamento. Posteriormente, Galeno (129-210 dC), em Roma, foi talvez o primeiro a realizar vivissecção com objetivos experimentais, ou seja, de testar variáveis através de alterações provocadas nos animais.

Em 1902, ULLMAN realizou um dos primeiros autotransplantes renais em cães, transplantando o rim de sua posição anatômica para os vasos do pescoço do mesmo animal. Neste mesmo ano realizou ainda, um alotransplante renal em cães, e posteriormente um xenotransplante de um cão para uma cabra ${ }^{148}$. Deu assim um passo gigantesco na utilização de modelos animais de experimentação e no desenvolvimento cirúrgico.

A primeira descrição de transplante renal em ratos foi apresentada em 1961 por Bernard Fisher e Sun Lee no American College of Surgeons Meeting em Chicago e posteriormente publicada em 1965 149, 150. O transplante foi realizado usando 
ratos de linhagens isogênicas Lewis (LEW) tanto como doador quanto como receptor.

Diversos modelos de transplante renal foram desenvolvidos ao longo dos anos, apresentando características distintas. Os modelos descritos são de rejeição aguda e de rejeição crônica.

Modelos experimentais de rejeição são desenvolvidos através da transplantação de órgãos entre animais de diferentes linhagens ou entre animais de linhagem alogênica. Os transplantes desenvolvidos utilizando animais inbred de linhagens distintas, apresentam uma maior homogeneidade quanto as características histopatológicas em comparação aos transplantes que utilizam linhagens outbred, isso ocorre devido a estabilidade genética dos animais inbred. Ratos de linhagens isogênicas (inbred) são obtidos a partir de cruzamentos entre irmãos (endocruzamentos) da mesma geração por, pelo menos, 20 gerações consecutivas em pares monogâmicos permanentes. O resultado garante características de uniformidade genética. Animais outbred são animais originados a partir de cruzamentos entre proles de diferentes casais (matrizes).

Animais criados no método inbred da mesma linhagem são isogênicos e, portanto, não rejeitam o enxerto.

Um dos modelos de rejeição aguda utiliza ratos isogênicos das linhagens Dark Agouti (DA) como doadores e ratos Lewis (LEW) como receptores. A rejeição do rim transplantado entre estas linhagens animais decorre devido a uma disparidade no MHC de classe I, conhecido em ratos como RT1. Desta forma 
associação de padrões haplótipos polimórficos RT1 dos doadores distintos dos receptores resulta na rejeição completa ao aloenxerto renal de forma rápida ${ }^{151}$, $152,153$.

A análise deste modelo revela a perda do enxerto renal entre 7 e 10 dias póstransplante ${ }^{154}$. Histopatológicamente apresenta uma evolução gradativa e acentuada da inflamação do enxerto, caracterizada inicialmente pela presença de infiltrado inflamatório perivascular, comprometendo principalmente a região adventícia das artérias e arteríolas. Com o avanço da doença a inflamação se agrava de maneira considerável acometendo o espaço perivascular e intersticial, e gerando dilatação tubular difusa. Os dias que se subseguem ao transplante um comprometimento acentuado da morfologia do parênquima renal é observado, evoluindo com lesões necróticas e hemorrágicas, culminando na rejeição total do órgão ${ }^{154}$.

O modelo experimental mais utilizado para o desenvolvimento de rejeição crônica do transplante é o de Fisher para Lewis (F344-LEW). O modelo experimental de transplante que utiliza ratos das linhagens Fisher e Lewis desenvolvido em 1969 por White e cols ${ }^{155}$ foi inicialmente concebido para estudar o progresso da rejeição crônica e as suas lesões patológicas associadas. Atualmente este modelo vem sendo utilizado em estudos destinados a sustentar a função renal e impedir a progressão da doença através do uso de imunossupressão ou imunomodulação. 
O transplante experimental utilizando-se como doador, órgãos ou tecidos de ratos Fisher 344 em receptores Lewis, reproduz as características da rejeição crônica, incluindo alterações funcionais e histológicas 156, 157. A resposta aloimune, ocorre pela disparidade parcial MHC ou RT1 entre doador e receptor. Em ratos Fisher e Lewis os loci RT1 classe I são RT1A, enquanto os de classe II são RT1 B/D. Os animais das linhagens F344 e LEW diferem nos loci do complexo menor de histocompatibilidade (não-MHC) em uma região conhecida como RT1 de classe III C/E/M, com haplótipos variantes nesta região: F344.RT1 ${ }^{1 \mathrm{v} 1}$ nos ratos Fisher e LEW.RT1' nos ratos Lewis ${ }^{158}$.

Assim, o isotransplante de animais LEW para animais LEW mantem a função renal preservada, contudo, os alotransplantes F344-LEW desenvolvem características clínicas e histopatológicas semelhantes às encontradas em pacientes com nefropatia crônica do enxerto, dentro de 3 meses pós-transplante. O alotransplante entre ratos F344-LEW sobrevive espontaneamente por um período superior a 6 meses, sem a necessidade do uso de drogas imunossupressoras ${ }^{159}$.

As análises morfofuncionais deste modelo revelam um aumento da pressão glomerular com proteinúria logo na primeira semana pós-transplante evoluindo gradativamente para nefropatia crônica do enxerto ${ }^{159}$. As mudanças histopatológicas ocorrem predominantemente nos glomérulos com expansão mesangial, espessamento fibrointimal dos vasos sanguíneos, dilatação dos capilares, divisão da membrana basal capilar e deposição de materiais 
eosinofílicos no lúmen capilar. Mudanças clássicas da nefropatia crônica do enxerto ocorrem simultaneamente ou posteriormente a estes achados ${ }^{150}$.

Segundo Heer e colaboradores, após um longo período pós-transplante os ratos LEW produzem anticorpos contra membrana basal glomerular e tubular. Subsequentemente foram detectados anticorpos dirigidos contra células mesangiais e endoteliais no soro e nos aloenxertos dos ratos transplantados. Análises mais profundas revelam que a ligação destes anticorpos ocorre predominantemente nas proteínas denominadas biglicana e decorina. 0 reconhecimento destas proteínas parece estar ligado a um reparo tecidual com a produção de matriz extracelular por fibroblastos, desencadeado pelo TGF- $\beta$.

O TGF- $\beta$ apresenta um papel fundamental na fibrogênese do aloenxerto renal. Ao se ligar ao seu receptor, desencadeia uma cascata intracitoplasmática e intranuclear complexa que resulta no aumento da transcrição de moléculas profibróticas, incluindo a-actina do músculo liso ( $\alpha$-SMA) e colágeno I, que induzem a ativação de miofibroblasto e deposição de matriz extracelular.

Diante do apresentado e tendo em vista a similaridade destes achados com os encontrados em pacientes com nefropatia crônica do transplante, podemos dizer que o modelo F344-LEW pode ser considerado um excelente modelo que mimetiza de forma robusta as alterações histomorfológicas encontradas em pacientes transplantados, podendo desta forma, ser utilizado com propriedade em estudos experimentais. 


\section{OBJETIVOS}

O objetivo principal do presente estudo foi analisar o efeito da terapia celular com células tronco mesenquimais derivadas de tecido adiposo (CTmTA) no modelo experimental de transplante renal em ratos, visando estudar seu efeito na rejeição crônica e avaliar seu potencial efeito imunomodulador.

\subsection{Objetivos Específicos}

1. Padronizar o modelo de rejeição crônica em ratos através da técnica de transplante renal experimental utilizando as linhagens isogênica Fisher $\left(R T 1^{11}\right)$ e Lewis $\left(R T 1^{\prime}\right)$;

2. Extrair, cultivar, expandir e caracterizar as CTmTA de ratos, por citometria de fluxo e por imunofluorescência utilizando marcadores de superfície positivos (CD90, CD44, CD29) e marcadores negativos (CD45, CD14 e CD19);

3. Analisar a função renal do enxerto através de parâmetros clínicos e laboratoriais, como níveis séricos de ureia e creatinina, proteinúria, pressão arterial, fração de excreção de sódio e potássio e clearance de creatinina;

4. Análisar a presença e intensidade de rejeição crônica, além de outros parâmetros histológicos de lesão renal, através da análise histológica dos enxertos renais 6 meses pós-transplante.

5. Analisar o efeito da administração das CTmTA nos mecanismos celulares, através da quantificação de macrófagos, linfócitos T e PCR em tempo real para citocinas pró-inflamatórias IL-6, IL-1 $\beta$, IFN- $\gamma$, TNF- $\alpha$ e imunomoduladoras IL-4 e IL-10. 


\section{MATERIAIS E MÉTODOS}

Toda metodologia aplicada no presente estudo foi desenvolvida em concordância com o guia institucional de cuidados no uso de animais de laboratório, com aprovação do Comitê de Ética na Utilização de Animais (CEUA) da Faculdade de Medicina da Universidade de São Paulo (Número 070/15).

\subsection{Modelo de Transplante Renal Experimental}

\subsubsection{Animais}

Os animais que foram utilizados no presente estudo consistem de linhagens isogênicas específicas de ratos Fisher $344(\mathrm{~F} 344)\left(R T 1^{1 / \mathrm{V}}\right)$ e ratos Lewis (LEW) (RT1). As matrizes destes animais são obtidas a partir de cruzamentos entre irmãos (endocruzamentos) da mesma geração por, pelo menos, 20 gerações consecutivas em pares monogâmicos permanentes oferecendo assim, uniformidade genética entre as linhagens.

Todos os animais foram criados no biotério local do laboratório de investigação médica 16 (LIM 16) da Faculdade de Medicina da Universidade de São Paulo, a partir de matrizes adquiridas comercialmente do Centro Multidisciplinar para Investigação Biológica (CEMIB) da Universidade de Campinas (UNICAMP). Ao chagarem, os animais permaneceram em quarentena para determinarmos quaisquer alterações fisiológicas e comportamentais. Após este período, matrizes contendo duas fêmeas para cada macho foram montadas e acompanhadas semanalmente para a determinação da prenhez. Antes do 
nacimento os machos foram retirados da gaiola e as femeas prenhas foram mantidas em isolamento para evitar o estresse excessivo e a consequente perda da ninhada. Após o nascimento, os filhotes permaneceram com as mães por 4 semanas, até serem separados e divididos em duas gaiolas contendo apenas machos ou fêmeas.

Todo estudo foi conduzido utilizando ratos F344 e ratos LEW machos para evitar heterogeneidade experimental relacionada ao gênero. Foram realizados 2 tipos de transplantes: Transplante de rim de ratos LEW para ratos LEW (transplante isogênico) e de ratos F344 para ratos LEW (transplante alogênico).

\subsubsection{Padronização do Modelo}

A padronização do modelo experimental de transplante de renal em ratos foi realizada utilizando microscópio cirúrgico (D.F.Vasconcellos, modelo bancada) e foi dividido em duas etapas: a primeira etapa baseou-se no treinamento de suturas cirúrgicas utilizando-se luvas de borracha como base para as anastomoses. Vários cortes foram feitos na luva simulando bordas de ferida que foram unidos com sutura contínua ou simples utilizando fios 7-0, 8-0, 9-0 e 10-0, mimetizando situações encontradas no ato cirúrgico. Em paralelo, foi realizado treinamento específico para reconhecer e manipular materiais de microcirurgia de acordo com a sequência dos tempos operatórios. A segunda etapa consistiu na sedimentação dos conhecimentos e habilidades adquiridos na etapa anterior através do treinamento de ligaduras, dissecção e ressecção de nervos, bem como arteriorrafia e venorrafia em animais destinados ao sacrifício. Após 
conhecer e executar as técnicas descritas, demos início à técnica de transplante renal ortotópico in vivo.

\subsubsection{A Cirurgia de Transplante Renal Experimental}

Os animais foram inicialmente pesados e então submetidos ao protocolo de transplante renal descrito por Daniller ${ }^{160}$. Após a indução anestésica através de injeção intraperitoneal de cetamina $(35,6 \mathrm{mg} / \mathrm{Kg})$ (Ketamin-S, Crisália) e xilazina $(5,7 \mathrm{mg} / \mathrm{Kg})$ (Ronpun, Bayer, Alemanha), foi realizada a tricotomia na região abdominal e assepsia com álcool iodado a $2 \%$. Todo o procesimento foi realizado com microscópio cirúrgico (D.F.Vasconcellos, modelo bancada).

a) A cirurgia no doador: $O$ acesso foi realizado por laparotomia xifopúbica mediana, com abertura da parede abdominal pela linha mediana, seguida da abertura da cavidade abdominal com ajuda de um micro afastador Finochietto. As alças intestinais foram cuidadosamente afastadas e envoltas em gaze umedecidas com solução fisiológica a temperatura ambiente. Em seguida, foi realizada a dissecação da artéria e veia renais, com a ajuda de duas micropinças cirúrgicas. Posteriormente, realizou-se a ligadura da aorta e veia cava infra-renal utilizando-se fio 4-0 algodão, para o bloqueio do fluxo sanguíneo, e em seguida a ligadura da aorta na região suprarrenal para realização da perfusão do rim do doador. Realizou-se a perfusão do órgão a partir da aorta com solução fisiológica heparinizada gelada a uma concentração de 50U/ml, por aproximadamente 5 min. Após a perfusão, com a ajuda de uma microtesoura, o rim foi retirado cortando-se a artéria e veia renal na região proximal em relação 
à aorta, e o ureter na região proximal a bexiga. $\mathrm{O}$ rim foi retirado da cavidade e mantido em solução fisiológica gelada por aproximadamente 2 minutos, até que o animal receptor fosse adequadamente posicionado na mesa cirúrgica.

b) A cirurgia no receptor: $O$ rim foi recolocado no receptor de forma ortotópica.O receptor foi preparado de forma semelhante ao doador, sendo que após a dissecção e isolamento da artéria e veia renal, um clamp vascular foi colocado obstruindo o fluxo sanguíneo ao rim esquerdo, e possibilitando sua retirada de forma simples com um corte perpendicular na artéria e veia renal, bem como no ureter, porém desta vez proximal em relação ao rim. Em seguida, o órgão do doador foi colocado na cavidade e a realização da anastomose pode ser iniciada. A conexão do enxerto foi realizada utilizando anastomoses do tipo término-terminal com pontos simples equidistantes entre si. Iniciamos o procedimento com a sutura da artéria renal, que foi realizada utilizando-se fio cirúrgico polipropileno 8-0 (PolySuture ${ }^{\circledR}$, São Sebastião do Paraíso, Brasil). Após o termino da anastomose arterial, iniciamos a anastomose venosa de forma semelhante à empregada na artéria renal. O rim foi umidecido durante todo o procedimento cirúrgico com solução fisiológica gelada.

Ao término das anastomoses, o clamp foi liberado reestabelecendo o fluxo sanguíneo. Após alguns minutos, iniciou-se a anastomose do ureter, com suturas tipo término-terminal e pontos simples de forma cardinal.

Finalmente, foi realizada a sutura da parede abdominal em dois planos: o primeiro com sutura da camada muscular com fio catgut simples 4-0 (Shalon ${ }^{\circledR}$, 
São Luis de Montes Belos, Brasil) e o segundo com sutura da pele com fio nylon 4-0 (Microsuture ${ }^{\circledR}$, São Paulo, Brasil). Ambas foram realizadas com pontos separados equidistantes entre si.

O tempo das anastomoses vasculares de cada animal foi medido e os valores comparados entre os grupos. Ainda, estabelecemos como meta o tempo máximo de anastomose de $30 \mathrm{~min}$, e tempo máximo isquemia de $40 \mathrm{~min}$ conforme descrito por Spanjol et al ${ }^{161} .0$ tempo total de isquemia a frio foi acompanhado durante o procedimento cirúrgico, e posteriormente analisado.

Dez dias pós-transplante os animais foram novamente submetidos a uma laparotomia para a retirada do rim remanescente (rim direito), permanecendo desta forma apenas com o rim transplantado.

Para a coleta de urína, os animais transplantados permaneceram 24 horas em gaiola metabólica. A urina foi armazenada em frascos apropriados e congelada em nitrogênio liquído para futuras análises. As amostras de sangue foram coletadas pela veia caldal com a ajuda de uma seringa. $\mathrm{O}$ volume máximo de 1 $\mathrm{ml}$ foi retirado para cada ponto de coleta.

Seis meses após a realização do transplante, os animais foram sacrificados e o enxerto renal foi retirado, bem como o sangue pela veia cava inferior. 


\subsubsection{Cuidados pós-operatórios}

Após o ato cirúrgico, todos os animais permaneceram em plataforma aquecida a $38^{\circ} \mathrm{C}$, até a recuperação total, que ocorreu aproximadamente 4 horas após a cirurgia. Todos os animais submetidos à cirurgia de transplante renal receberam Trama ${ }^{\circledR}($ Cloridrato de Tramadol, Medley, Campinas, Brasil) a uma concentração de $5 \mathrm{mg} / \mathrm{kg} / \mathrm{dia}$ via intramuscular.

Na reavaliação pós-operatória imediata (primeiras 12h após a cirurgia) a dose de Tramal ${ }^{\circledR}$ foi repetida em todos os animais e mantida durante 3 dias. Após este período não foram observados sinais de dor nos animais.

Após o ato cirúrgico, todos os animais submetidos ao transplante renal receberam dose única de antibiótico Penicilina/Streptomicina (Life Technologies, USA) a uma concentração de $150 \mathrm{mg} / \mathrm{kg}$ via subcutânea, 10 min após a cirurgia. O período pós-operatório foi de responsabilidade do pesquisador, sendo por ele julgada a necessidade de revisão cirúrgica ou eutanásia

\subsubsection{Eutanásia dos Animais}

Após o período do protocolo experimental, os animais foram eutanasiados através de injeção intraperitoneal do coquetel de cetamina/xilazina, administrado na dose de $100 \mathrm{mg} / \mathrm{kg}$ e $12 \mathrm{mg} / \mathrm{kg}$ respectivamente.

Com os animais anestesiados foi realizada a punção do ventrículo esquerdo com "butterfly" 21G (KDL ${ }^{\circledR}$, Guarulhos, Brasil) e a coleta de sangue com auxílio de uma seringa de $5 \mathrm{~mL}$. Imediatamente após a coleta sanguínea, a perfusão do órgão através da artéria renal foi iniciada com solução fisiológica heparinizada 
na concentração de $50 \mathrm{U} / \mathrm{ml}$. Após a perfusão total, o rim pode ser retirado e processado.

\subsection{Extração de CélulasTronco de Tecido Adiposo}

As CTm foram isoladas de tecido adiposo obtidas da região gonadal de ratos Lewis machos, com idade entre 8 e 12 semanas, conforme descrito previamente por Estes et al ${ }^{161}$. Os detalhes do isolamento são descritos mais adiante nos itens 3.8.

\subsection{Desenho do Estudo}

O transplante renal experimental foi realizado de forma ortotópica, utilizando-se

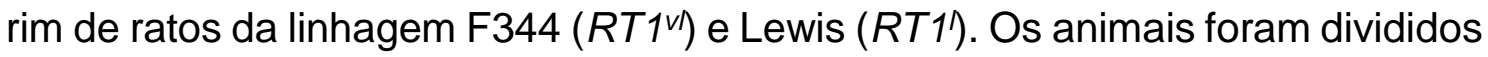
em três grupos ISO (transplante isogênico de Lewis para Lewis, n=6), ALO (transplante alogênico de Fisher para Lewis, $n=6$ ) e ALO+CTmTA (transplante alogênico, tratado com CTmTA, n=6). Dez dias pós-transplante os animais foram novamente submetidos a uma laparotomia mediana para a nefrectomia do rim remanescente. Após a retirada do rim, as CTmTA isoladas foram infundidas $\left(10^{6}\right.$ células) via subcapsular. Um mês e três meses pós-transplante novas infusões de $10^{6}$ de CTmTA foram realizadas por via intraperitoneal. Os animais foram acompanhados por 6 meses e as análises de pressão caudal, função renal, histologia, imunohistoquímica e PCR real time foram realizadas. 
Os animais foram divididos nos seguintes grupos:

ISO: $\quad$ Animais submetidos ao isotransplante de rim (Lewis $\rightarrow$ Lewis)

$(n=6)$

ALO: $\quad$ Animais submetidos ao alotransplante de rim (F344 $\rightarrow$ Lewis) $(n=6)$

ALO+CTmTA: Animais submetidos ao alotransplante de rim (F344 $\rightarrow$ Lewis) $(n=6) \quad$ que receberam terapia com CTMTA.

\section{Protocolo experimental}

\section{ALO+CTMTA}

\section{ALO}

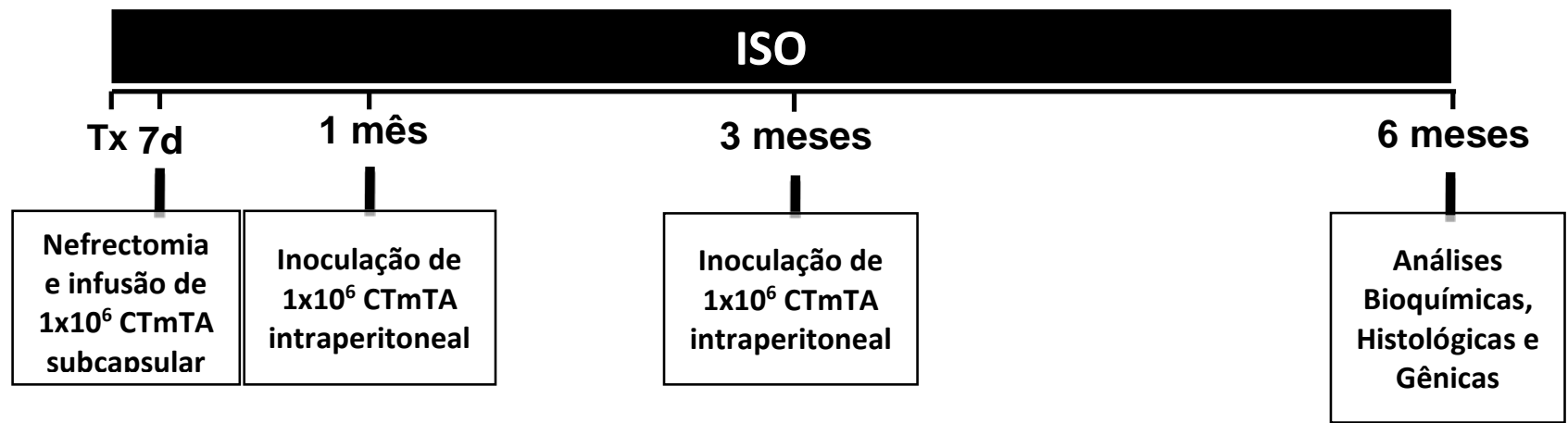




\subsection{Avaliação Clínica e Bioquímica}

\subsubsection{Evolução ponderal e peso renal}

Os animais transplantados foram acompanhados por um período de 6 meses verificando-se a evolução ponderal no dia 7 e nos meses 1, 3 e 6 pós-transplante, além de verificar possíveis alterações clínicas.

No momento da eutanásia, os enxertos renais foram retirados e imediatamente pesados em balança de precisão para determinação do peso renal.

\subsubsection{Pressão caudal}

A pressão caudal dos animais foi mensurada pelo método de pletismografia de cauda nos meses 1, 3 e 6 pós-transplante. Os animais foram colocados em um contensor e o cuff de pressão foi colocado na base do rabo.Em seguida o sensor de pressão foi colocado em uma porção mais medial do rado e as mensurações foram feitas. A média de 5 aferições para cada animal foi utilizada como resultado final.

\subsubsection{Análises bioquímicas}

A determinação da proteinúria, uréia sérica, creatinina sérica e urinária, sódio e potássio plasmáticos e urinários foram realizadas utilizando o método automatizado Cobas C111 analyzer (Roche, Indianapolis, EUA). Para a coleta da urína os animais foram mantidos em gaiola metabólica por 24 horas. 0 sangue dos animais foi coletado pela veia caudal com a ajuda de uma seringa agulhada. O sangue foi então centrifugado para a separação do soro. Tanto a 
urina quanto o soro foram congelados em nitrogênio e armazenados no freezer -80 até o momento da análise.

\subsubsection{Clearance de Creatinina}

O cálculo para determinação da estimativa de filtração glomerular foi realizado conforme a equação abaixo. Os resultados foram apresentatos em $\mathrm{ml} / \mathrm{min}$.

$$
\frac{\mathrm{Cr} \text { urinária }(\mathrm{mg} / \mathrm{dL}) \times \frac{\text { Vol urinário } 24 \mathrm{~h}(\mathrm{ml})}{1440(\mathrm{~min})}}{\operatorname{Cr} \text { sérica }(\mathrm{mg} / \mathrm{dL})}
$$

\subsubsection{Fração de excreção de sódio e potássio}

O cálculo da fração de excreção de sódio e potássio foram realizados conforme as equações abaixo. Os resultados foram apresentados em porcentagem.

$$
\begin{gathered}
\frac{\mathrm{Na}^{+} \text {urinário }(\mathrm{mEq} / \mathrm{L}) \times \mathrm{Cr} \text { sérica }(\mathrm{mg} / \mathrm{dL})}{\mathrm{Cr} \text { sérica }(\mathrm{mg} / \mathrm{dL}) \times \mathrm{Na}^{+} \text {sérico }(\mathrm{mEq} / \mathrm{L})} \times 100 \\
\mathrm{e} \\
\frac{\mathrm{K}^{+} \text {urinário }(\mathrm{mEq} / \mathrm{L}) \times \mathrm{Cr} \text { sérica }(\mathrm{mg} / \mathrm{dL})}{\mathrm{Cr} \text { sérica }(\mathrm{mg} / \mathrm{dL}) \times \mathrm{K}^{+} \text {sérico }(\mathrm{mEq} / \mathrm{L})} \times 100
\end{gathered}
$$




\subsection{Histologia}

O rim transplantado foi cuidadosamente dissecado, retirado e lavado com solução fisiológica gelada e perfundido com formaldeído 4\% para fixação. Em seguida, o fragmento foi colocado em caixeta perfurada e mantido em solução de formaldeído $4 \%$ em tampão fosfato por $24 \mathrm{~h}$ até a inclusão em blocos de parafina.

O processo de inclusão foi realizado pelo processador automatizado de tecido histoquinete (Jung-Histokinette 2000 Leica, Nussloch, Alemanha) e com duração aproximada de 14 horas. O processo se inicia pela desidratação dos tecidos em álcoois com concentrações progressivas (álcool 50\%, álcool 70\%, álcool 96\% (2 banhos), e álcool absoluto (2 banhos), seguida da diafanização, passando os tecidos em uma solução de álcool absoluto + xilol (3 banhos), sendo então imersos em parafina fundida a $60^{\circ} \mathrm{C}$. O material parafinizado foi incluído em blocos e permaneceram em temperatura ambiente até a utilização.

Os blocos de parafina foram cortados em micrótomo (Reichert Yung Supercut 2065 Leica, Nussloch, Alemanha) com navalhas descartáveis. Os cortes, com espessura entre 3 e $4 \mu \mathrm{m}$, foram aderidos em lâminas previamente revestidas por silano 2\% (Sigma Chemical CO, St. Louis, EUA), que permaneceram em estufa (Fabbe-Primar, São Paulo, Brasil) a $60^{\circ} \mathrm{C}$ por 2 horas e em seguida foram armazenadas em temperatura ambiente até a utilização.

As lâminas passaram por um processo de desparafinização, através deimersão em xilol por 9 minutos (Merck, Darmstadt, Alemanha) por 3 vezes. Em seguida, 
as lâminas foram reidratadas, através de banho em etanol absoluto por 5 minutos (2 vezes) (Merck, Darmstadt, Alemanha), e em seguida, passaram por banhos de etanol $96 \%$ por3 minutos (2 vezes). Para finalizar este processo, as lâminas foram imersas em água destilada e processadas.

\subsubsection{Coloração Tricrômio de Masson}

Após a desparafinização, as lâminas foram incubadas em Hematoxilina de Harris (Merck, Darmstadt, Alemanha) por 3 minutos e 30 segundos, e em seguida em solução de Cromotrop (Cromotrop + Azul de Anilina + Ácido Fosfotungstico) por 25 minutos. As lâminas foram então lavadas em água destilada e imediatamente desidratadas na sequência de banhos de etanol e xilol a partir do etanol $96 \%$.

Para a quantificação da fibrose intersticial por Tricromio de Masson, foi utilizada a técnica de pontos, onde uma malha de 176 pontos foi colocada sobre a área total do campo no monitor, e os pontos que caíram sobre a área marcada foram contador. O resultado foi expresso em porcentagem.

\subsection{Imuno-Histoquímica}

\subsubsection{Marcadores Inflamatórios: Macrófagos e Linfócitos T}

Com o objetivo de aumentar a expressão antigênica, após a desparafinização, as lâminas foram imersas em tampão citrato $10 \mathrm{mM}, \mathrm{pH}=6,0$ e levados em forno micro-ondas (Sanyo, São Paulo, Brasil) com potência de 2400 watts durante 15 
minutos. Após atingir a temperatura ambiente, as lâminas foram lavadas com água destilada para a retirada do tampão citrato e transferidas para TBS (Tris buffered saline), $\mathrm{pH}=7,6$.

Para o bloqueio da biotina endógena os cortes foram incubados com solução de avidina D (Vector, Burlingame, EUA) durante 15 minutos, sendo posteriormente lavadas com TBS durante 5 minutos. Em seguida, os cortes foram incubados com uma solução de biotina (Vector, Burlingame, EUA) durante 15 minutos e posteriormente lavados com TBS por 5 minutos. Os cortes foram então incubados com Protein Block (Spring Bioscience, Pleasanton, EUA), diluído 70 vezes em TBS, durante 30 minutos e, após a retirada do excesso do soro, os cortes foram incubados com o anticorpo primário anti-ED-1 (1:200) ou anti-CD43 (1:100), durante a noite, a $4^{\circ} \mathrm{C}$.

Os macrófagos foram identificados no enxerto renal através do anticorpo monoclonal anti-monócito/macrófago de rato (anti-ED-1) na diluição 1:400 (Serotec, Raleigh, EUA), produzido em camundongo. Para a identificação de linfócitos $\mathrm{T}$ foi utilizado o anticorpo de camundongo anti-linfócito $\mathrm{T}$ de rato na diluição de 1:400 (anti CD3) (Serotec, Raleigh, EUA). O método LSAB-AP (Labeled Streptavidin-Biotin Alcaline Phosphatase - Dako, Carpinteria, USA) foi utilizado para a localização destes anticorpos e todo o procedimento foi realizado em câmara úmida.

No dia seguinte, os cortes foram lavados em TBS por 5 minutos e incubados com o "pool" de anticorpos biotinilados anti-camundongo, anti-coelho e anti-cabra 
(Dako, Carpinteria, EUA) por 30 minutos. Após lavagem com TBS, para completar a reação, os cortes foram incubados com o complexo estreptavidinabiotina-fosfatase alcalina (Dako, Carpinteria, EUA) por 30 minutos e lavados novamente com TBS e destinados à revelação.

Para a revelação, os cortes foram incubados com uma solução contendo substrato para a enzima fosfatase e o corante fast-red (Sigma Chemical, Saint Louis, EUA), preparada da seguinte maneira: $1 \mathrm{mg}$ de fosfato de naftol AS-MX (Sigma Chemical, Saint Louis, EUA) diluídos em $100 \mu \mathrm{L}$ de dimetilformamida (Merck, Darmstadt, Alemanha). Em seguida, a solução foi diluída em 4,9 mL de tampão Tris $0,1 \mathrm{M}(\mathrm{pH}=8,2)$ e $10 \mu \mathrm{L}$ de levamisol $1 \mathrm{M}$ (Sigma Chemical, Saint Louis, EUA) foram acrescentados. Esta solução permaneceu armazenada a$20^{\circ} \mathrm{C}$ e, no momento da revelação foi misturada com $5 \mathrm{mg}$ do corante fast-red.

A revelação foi realizada sob microscopia em aumento de $100 \mathrm{X}$ e as células positivas apresentam coloração avermelhada. O tempo de revelação foi de aproximadamente 10 minutos. As lâminas foram contracoradas com Hemalum de Mayer (Merck, Darmstadt, Alemanha) durante 1 minuto, lavadas em água destilada e montadas com glicergel (Merck, Darmstadt, Alemanha).

Para avaliar a expressão de macrófago e linfócito-T, no córtex e na medula, foram analisados 50 campos no aumento de 400 vezes. 


\subsection{Expressão Gênica de interleucinas pró-inflamatórias e anti-inflamatórias}

\subsubsection{Extração de RNA total}

Todas as soluções utilizadas para a extração de RNA foram realizadas com água deionizada através do sistema Milli-Q (Millipore, Milli-Q Element A10 System, Massachusetts, EUA) e tratadas com dietilpirocarbonato (Sigma, Sto Louis, EUA). Para cada litro de água deionizada, foram adicionados $1,0 \mathrm{~mL}$ de dietilpirocarbonato e a solução foi mantida a $60^{\circ} \mathrm{C}$ sob agitação por aproximadamente 12 horas, sendo em seguida autoclavada (121ํㅡ por 20 minutos).

O RNA total do enxerto renal foi extraído pelo método de Trizol (Invitrogen, Carlsbad, EUA), seguindo-se o protocolo sugerido pelo fabricante. Cada $100 \mathrm{mg}$ de tecido foi homogenizado com $1 \mathrm{~mL}$ de Trizol com auxílio de um dispersador de tecidos (IKA - Labortechnik Ultra Turrax T25 Janke \& Kunkel, Alemanha). A cada $\mathrm{mL}$ de homogenato, foram adicionados $200 \mu \mathrm{L}$ de clorofórmio (Merck, Darmstadt, Alemanha), a mistura foi novamente homogeneizada e mantida por 3 minutos a temperatura ambiente.

Após a incubação, a mistura foi centrifugada a $12.000 \mathrm{~g}$ a $4^{\circ} \mathrm{C}$ por 20 minutos. $\mathrm{A}$ fase superior contendo RNA foi transferida para um microtubo de $2 \mathrm{~mL}$ contendo o mesmo volume de isopropanol gelado (Sigma Chemical Co, Saint Louis, EUA). As amostras foram centrifugadas a $12.000 \mathrm{~g}$ durante 10 minutos, o sobrenadante foi descartado, o pellet de RNA ressuspendido em $1 \mathrm{~mL}$ de etanol 70\% (Merck, 
Darmstadt, Alemanha) e centrifugado novamente a $12.000 \mathrm{~g}$ por 10 minutos. Este procedimento foi repetido e o pellet resuspendido com $50 \mu \mathrm{L}$ de água previamente tratada com dietilpirocarbonato.

\subsubsection{Quantificação do RNA total}

A quantificação do RNA foi realizada em espectrofotômetro (NanoDrop, Thermo Fisher Scientific, Marietta, EUA) medindo-se absorbância nos comprimentos de onda 260 e $280 \mathrm{~nm}$. O cálculo da concentração de RNA expresso em $\mu \mathrm{g} / \mathrm{mL}$ foi realizado a partir da absorbância a $260 \mathrm{~nm}$. A leitura de 1 OD corresponde a uma solução pura de RNA em fita-simples na concentração de $40 \mu \mathrm{g} / \mathrm{mL}$. A leitura a $280 \mathrm{~nm}$ foi utilizada para determinar a contaminação das amostras com proteínas. A análise foi baseada na razão entre as absorbâncias a 260 e 280nm, sendo o valor aceitável de 1,7 a 2,0.

\subsubsection{Síntese de cDNA}

Todos reagentes utilizados para a reação de síntese do DNA complementar (cDNA) foram da marca Promega (Promega, San Luis Obispo, EUA). Um microlitro de oligo dT primer $(500 \mu \mathrm{g} / \mathrm{ml})$ foi misturado a $11 \mu \mathrm{l}$ de uma solução de RNA a $50 \mathrm{ng} / \mu \mathrm{l}$. A solução foi aquecida a $70^{\circ} \mathrm{C}$ por 10 minutos e resfriada em gelo por 5 minutos. Em seguida, foi acrescentado $4 \mu \mathrm{l}$ de tampão [5X] (Tris-HCl $250 \mathrm{mM} \mathrm{pH}=8,3, \mathrm{KCL} 375 \mathrm{mM}, \mathrm{MgCl} 215 \mathrm{mM}), 2 \mu \mathrm{l}$ de DTT 0,1M, $1 \mu \mathrm{l}$ de dNTP Mix (10mM de dATP, dGTP, dCTP e dTTP) e $1 \mu \mathrm{l}$ (200u) da enzima transcriptase reversa M-MLV (Moloney Murine Leukemia Virus). A reação foi realizada a $42^{\circ} \mathrm{C}$ por 50 minutos, passando posteriormente por um período de 15 minutos a $70^{\circ} \mathrm{C}$ 
para a inativação da enzima. O cDNA foi mantido em freezer a $-20^{\circ} \mathrm{C}$ até a realização da reação de PCR em tempo real.

Para esta etapa foram confeccionados pares de primers para a obtenção de amplicons com no máximo 250 pb, conforme a recomendação para PCR em tempo real.

\subsubsection{PCR em tempo real: $q P C R$}

Para a reação de PCR em tempo real foi utilizado o kit SYBR GreenEr qPCR SuperMix Universal (Invitrogen, Califórnia, EUA). Neste protocolo, $1 \mu \mathrm{L}$ de cDNA foi acrescido a 7,5 $\mu \mathrm{L}$ de mix do kit, 0,6 $\mu \mathrm{L}$ de primer foward $(10 \mu \mathrm{M}), 0,6 \mu \mathrm{L}$ de primer reverse $(10 \mu \mathrm{M}), 5,75 \mu \mathrm{L}$ de água deionizada e $0,15 \mu \mathrm{L}$ de Rox. Todas as reações foram realizadas em triplicatas. A mistura foi aquecida a $50^{\circ} \mathrm{C}$ por 10 minutos e depois a 95ํㅡ por 5 minutos, seguindo 40 ciclos de $95^{\circ} \mathrm{C}$ por 15 segundos, $60^{\circ} \mathrm{C}$ por 30 segundos e $72^{\circ} \mathrm{C}$ por 30 segundos. A curva de melting foi feita à $65^{\circ} \mathrm{C}$ com variação de $1^{\circ} \mathrm{C}$.

O equipamento utilizado foi o StepOnePlus ${ }^{\mathrm{TM}}$ Real-Time PCR System (Applied Biosystems, Singapura). A expressão gênica foi determinada como a expressão relativa entre o gene alvo e o gene housekeeping $\beta$-actina, calculadas pelo software do aparelho StepOnePlus ${ }^{\mathrm{TM}}$ Real-Time PCR System (Applied Biosystems, Singapura), a partir dos cycle threshold (CT) das reações. 


\subsubsection{Primers utilizados reação de PCR}

Os primers utilizados foram pesquisados na base de dados GenBank (http://www.ncbi.nlm.nih.gov/genbank/) e escolhidos através do programa primer blast.

Tabela 1: Sequência dos primers utilizados e a temperatura de melting utilizada em cada gene

\begin{tabular}{|c|c|c|c|}
\hline GENE & Primers & $\begin{array}{c}\text { Produto } \\
\text { (pb) }\end{array}$ & $\begin{array}{l}\mathrm{Tm} \\
\left({ }^{\circ} \mathrm{C}\right)\end{array}$ \\
\hline \multirow{2}{*}{$18-S$} & 5' AGGAGTACGATGAGTCCGGCCC 3' & \multirow{2}{*}{70} & 59,54 \\
\hline & 5' GCAGCTCAGTAACAGTCCGCCT 3' & & 58,91 \\
\hline \multirow{2}{*}{ IL1- $\beta$} & 5' CCTTGTGCAAGTGTCTGAAGCAGC 3' & \multirow{2}{*}{248} & 58,97 \\
\hline & 5' GCCACAGCTTCTCCACAGCCA 3' & & 59,31 \\
\hline \multirow{2}{*}{ IL-6 } & 5' CCGGAGAGGAGACTTCACAGAGGA 3' & \multirow{2}{*}{71} & 59,69 \\
\hline & 5' AGCCTCCGACTTGTGAAGTGGTATA 3' & & 57,25 \\
\hline \multirow{2}{*}{ IFN- $\gamma$} & 5' TCTGGAGGAACTGGCAAAAGGA 3' & \multirow{2}{*}{3,87} & 55,50 \\
\hline & 5' TCAAGACTTCAAAGAGTCTGAGGTAGA 3' & & 55,00 \\
\hline \multirow{2}{*}{ TNF- $\alpha$} & 5' TGGCCCAGACCCTCACACTCA 3' & \multirow{2}{*}{541} & 59,15 \\
\hline & 5' GGCTCAGCCACTCCAGCTGC 3' & & 60,04 \\
\hline \multirow{2}{*}{ IL-4 } & 5' TGGCCCAGACCCTCACACTCA 3' & \multirow{2}{*}{65} & 58,97 \\
\hline & 5' CTGAAAAGTGGAGCAGTCATT 3' & & 59,31 \\
\hline \multirow{2}{*}{ IL-10 } & 5' TGGGTCTCAGCCCCCACCTT3' & \multirow{2}{*}{82} & 59,54 \\
\hline & 5' TCCGTGGATACCGTTCCCGGT3' & & 58,91 \\
\hline
\end{tabular}




\subsection{Obtenção de Células Tronco Mesenquimais}

\subsubsection{Extração de células de tecido adiposo e isolamento de CTm}

Os ratos doadores foram anestesiados com cloridrato de cetamina (Ketamina-S, Cristália, São Paulo, Brasil) e Xilazina (Rompun, Bayer, Leverkusen, Alemanha) na dose de $70 \mathrm{mg} / \mathrm{kg}$, e em seguida foi realizada a assepsia da região abdominal com sabão clorexidina, seguido de álcool 70\%. Com o auxílio de um bisturi fezse uma incisão na linha mediana somente na pele, em seguida a cavidade abdominal foi aberta a fim de localizar o tecido adiposo gonadal. O tecido foi exposto e removido com o auxílio de uma tesoura. $\mathrm{O}$ tecido adiposo foi colocado em um tubo cônico Falcon (Becton Dickinson, San Jose, EUA) de $50 \mathrm{ml}$ contendo Phosphate Buffered Saline (PBS) para retirada do excesso de sangue. Após a lavagem o tecido adiposo foi mantido em DMEMlow glicose $1 \%(\mathrm{pH}=7,6)$, acrescido de 20mg de colagenase tipo A, 200mg de Albumina Sérica Bovina (BSA) e $10 u \mathrm{~L}$ de gentamicina e mantido em banho-maria a $37^{\circ} \mathrm{C}$ por 30 minutos agitando o recipiente a cada 5 minutos.

Após a digestão completa do tecido, e reação foi interrompida adicionando $10 \mathrm{ml}$ de Soro Fetal Bovino (SFB). O tecido foi então submetido a uma centrifugação de 15 minutos a 1500rpm, o sobrenadante foi desprezado e o botão de células foi ressuspenso com 1,0 mL de DMEM low glucose (Gibcolnvitrogen, Rockville, EUA) contendo soro fetal bovino a 10\% (SFB) (Cultilab, Campinas, Brasil). Desta suspensão, 10,0 $\mu \mathrm{L}$ foram transferidos para um microtubo de $1,0 \mathrm{~mL}$, contendo $90,0 \mu \mathrm{L}$ de uma solução de azul de trypan blue (0,25\%). O material foi homogeneizado e 10,0 $\mu \mathrm{L}$ da suspensão foram colocados em cada face de uma 
câmara de Neubauer para a contagem de células viáveis, em 16 campos. 0 número médio de células obtido foi multiplicado por 10 (fator de diluição com a solução de azul trypan) e por $10^{4}$ (fator da câmara de Neubauer), a fim de se determinar a concentração celular da suspensão (células por mililitro).

Em seguida, essas células foram cultivadas em garrafas estéreis de $75 \mathrm{~cm}^{2}$ (Corning Life Science, Lowell, EUA) próprias para cultivo celular e mantidas em estufa a $37^{\circ} \mathrm{C}$, a $5 \%$ de $\mathrm{CO} 2$ (Thermo Fisher Scientific, Marietta, EUA). A troca do meio de cultura foi realizada a cada 3 dias até a obtenção de confluência celular de $80 \%$.

\subsubsection{Método de tripsinização}

Quando as células em cultura atingiram a confluência, com crescimento em colônia e formato fibroblastóide, o meio de cultura foi retirado e as células lavadas com PBS estéril por 3 vezes. Para a tripsinização foram adicionados 3,0 $\mathrm{mL}$ de solução de tripsina $0,25 \%$ (Gibco-Invitrogen, Rockville, EUA) a $37^{\circ} \mathrm{C}$ por 3 minutos. Estas garrafas foram agitadas levemente para o desprendimento total das células e em seguida, para inibir a ação da tripsina, foi utilizado meio de cultura suplementado com SFB 10\%. Depois, as células foram transferidas para tubos cônicos de 15,0 mL (Becton Dickinson, San Jose, EUA) e centrifugados (290g por 5 minutos a 4ํㅡ, (centrífuga Eppendorf 5810R, Hamburg, Alemanha). O sobrenadante foi desprezado e o botão celular foi ressuspenso com 1,0 mL de meio de cultura completo (DMEM-low glucose+ 10\%SFB + antibióticos). Em seguida foi realizada a contagem de células viáveis utilizando a coloração de 
azul de trypan, e a partir dessa contagem as células foram novamente plaqueadas. A tripsinização e o replaqueamento das células são determinados como passagem celular.

\subsubsection{Cultivo e expansão das CTmTA}

Após a contagem celular, foram cultivadas em garrafas de $75 \mathrm{~cm}^{2}$ (Corning Life Science, Lowell, EUA), contendo meio de cultura completo e incubadas em estufa úmida a $37^{\circ} \mathrm{C}$ a $5 \%$ de CO2 (Thermo Fisher Scientific, Marietta, EUA). meio de cultura foi trocado 3 vezes por semanae o cultivo celular foi monitorado sob microscopia invertida. As células foram replicadas sempre que atingiram uma confluência de $80 \%$. Então, eram novamente tripsinizadas, contadas e replaqueadas. As células utilizadas para este projeto foram mantidas em cultura até a $5^{\underline{a}}$ passagem celular.

\subsubsection{Caracterização das CTmTA por citometria de fluxo}

A caracterização das populações celulares presentes nas amostras celulares foi determinada pelo método de citometria de fluxo. A presença dos marcadores celulares foi verificada através de diferentes anticorpos monoclonais (Tabela 1) conjugados com diferentes fluorocromos: isotiocianato de fluoresceína (FITC, do inglês fluorescein isothiocyanate) e ficoeritrina ( $P E$, do inglês phycoeritrin). Controles de marcações inespecíficas foram utilizados para a adequada calibração do aparelho, análise dos resultados e definição da positividade da amostra. Todos os anticorpos foram adquiridos da empresa eBioscience, San Diego, CA. 
Tabela 2. Anticorpos utilizados para caracterização das células isoladas de Tecido Adiposo como CTmTA

\begin{tabular}{|c|c|c|c|c|}
\hline Anticorpos & Especificidade & $\begin{array}{c}\text { Fluorocromo } \\
\text { Conjugado }\end{array}$ & Isotipo & Concentração \\
\hline Anti-CD29 & CTm & FITC & $\begin{array}{c}\text { Armenian } \\
\text { Hamster } \\
\lg G\end{array}$ & $0.5 \mathrm{mg} / \mathrm{mL}$ \\
\hline Anti-CD44 & CTm & PE & $\begin{array}{l}\text { Mouse } \\
\text { IgG2a, } \\
\text { Kappa }\end{array}$ & $0.2 \mathrm{mg} / \mathrm{mL}$ \\
\hline Anti-CD45 & $\begin{array}{c}\text { Pan- } \\
\text { leucocitário }\end{array}$ & FITC & $\begin{array}{l}\text { Mouse } \\
\text { lgG1, } \\
\text { Kappa }\end{array}$ & $0.2 \mathrm{mg} / \mathrm{mL}$ \\
\hline Anti-CD90-1 & CTm & FITC & $\begin{array}{l}\text { Mouse } \\
\text { IgG2a, } \\
\text { Kappa }\end{array}$ & $0.5 \mathrm{mg} / \mathrm{mL}$ \\
\hline Anti-CD-105 & CTm & PE & $\begin{array}{l}\text { IgG2a, } \\
\text { Kappa }\end{array}$ & $0.2 \mathrm{mg} / \mathrm{mL}$ \\
\hline Anti MHC II & APC & PE & $\begin{array}{l}\text { Mouse } \\
\lg \mathrm{G} 1\end{array}$ & $0.2 \mathrm{mg} / \mathrm{mL}$ \\
\hline
\end{tabular}

As células obtidas e quantificadas como descritas anteriormente foram ajustadas à concentração de $2,5 \times 10^{5}$ em $100 \mu \mathrm{L}$. Em seguida, $100 \mu \mathrm{L}$ foram transferidos para um tubo específico para citometria (Becton Dickinson, San Jose, EUA) e incubados com os anticorpos conjugados aos fluorocromos por um período de 30 minutos, em campo escuro, a $4^{\circ} \mathrm{C}$. Em seguida, foi acrescentado1,0 $\mathrm{mL}$ de PBS gelado e a solução foi agitada com ajuda de um vortex. Posteriormente os tubos foram centrifugados a 2000rpm por 6 minutos a temperatura ambiente (Eppendorf 5810R, Hamburg, Alemanha). O sobrenadante foi descartado e o precipitado celular foi homogeneizado e ressuspenso em $500 \mu \mathrm{L}$ de solução de 
formaldeído diluído a 1\% em PBS (Formaldeído PA, Vetec, Brasil) e estocado em geladeira ao abrigo da luz por um período máximo de 24 horas, até o momento da leitura no citômetro de fluxo.

As células foram adquiridas e a intensidade de fluorescência foi captada pelo citômetro de fluxo no aparelho FacsCanto (Becton Dickinson, San Jose, CA. EUA). Os dados foram analisados no CELLQuestTM (Becton Dickinson, San Jose, CA EUA). Para cada amostra foi realizada uma aquisição de 20.000 eventos. Os resultados foram fornecidos e analisados na forma de histogramas e em percentual da população celular com reação positiva para cada anticorpo.

\subsubsection{Caracterização das CTmTA por Imunofluorescência}

As células foram mantidas em cultura até a quinta passagem em lamínulas. Após atingirem a confluência, as células foram lavadas em PBS durante 5 minutos por 3 vezes. As células foram então fixadas em PFA $1 \%$ por 10 minutos a temperatura ambiente $\left(0.1 \mathrm{~g}\right.$ paraformaldeido em $10 \mathrm{ml} \mathrm{H} \mathrm{H}_{2} \mathrm{O}$ pré-aquecida a $60^{\circ} \mathrm{C}$, e diluido 1:1 com 2x PBS, $\mathrm{pH} 7.4$ ). As células foram lavadas com PBS tween, por 15 minutos. Após isso, deu-se início ao Bloqueio-l de ligações inespecíficas que foi realizado com Glicina $(100 \mathrm{mM})$ em PBS tween por 5 minutos. A permeabilização com Triton $x-100$ 0,2\% em PBS por 3 minutos, as lamínulas foram então lavadas em PBS tween, 3x por15 minutos. Um segundo bloqueio (Bloqueio-II) de ligações inespecíficas foi realizado utilizando-se albumina bovina $5 \%$ em PBS por 30 minuto a temperatura ambiente 
As lamínulas foram então incubadas com os anticorpos monoclonais primários específicos anti-H-CAM, anti-THY-1, anti-STRO-1, anti-MCAM, anti-CD19, anti CD-14 (Human Mesenchymal Stem Cell Characterization Kit - Cat SCR067Milipore, EUA) diluídos 1:50 e anti-CD73 e anti-CD45 (Santa Cruz Biotechnology) diluídos 1:30, por 1 hora, a temperatura ambiente em câmara úmida.

Após a incubação, as lamínulas foram lavadas em PBS por 10 minutos 3X. Em seguida, foramincubadas com os anticorpos secundários conjugados ao fluoróforosAlexa 488 anti-mouse (Life Technologys) para anti-H-CAM, anti-THY1, anti-STRO-1, anti-MCAM, anti-CD19, anti CD-14, com Alexa 594 anti-goat (Life Technologys) para anti-CD73 eAlexa 546 anti-rabbit para anti-CD45 (Santa Cruz Biotechnology), diluídos 1:400 por uma hora a temperatura ambiente em câmara úmida. Após este período, as lamínulas foram então lavadas emPBS, 3x por 10 minutos e em seguida Incubadas com DAPI $10 \mu \mathrm{g} / \mathrm{ml}$ (4'6-diamidino-2phenylindole) (Invitrogen) por 10 minutos em câmara úmida e escura. As lamínulas novamente Lavadas em PBS, 3x por 10 minutos e montadas com glicerol/PBS 1:1 em lâminas para microscopia.

\subsubsection{Diferenciação das CTmTA}

a) Diferenciação das CTm em células osteogênicas: A diferenciação osteogênica de CTmTA de rato Lewis foi executada seguindo o protocolo de (Morigi et al, 2004). As células aderentes foram cultivadas em placas de 6 poços na densidade celular de $5 \times 10^{3}$ céls $/ \mathrm{mL}$, com meio DMEM-low glicose mais SFB a 10\%, acrescido de GlutaMax-I (200mM) e Gentamicina (10mg/mL) por 4 dias. 
A seguir foi realizada a substituição do meio de cultura por um meio condicionado, próprio para diferenciação osteogênica STEMPROß Osteocyte Differentiation Basal Medium, STEMPRO® Osteogenesis Supplement e Gentamicina $(10 \mathrm{mg} / \mathrm{mL})$. A troca de meio de diferenciação foi realizada a cada 3 dias pelo período de 21 dias. A placa foi mantida em estufa úmida a $37^{\circ} \mathrm{C}$ a $5 \%$ de CO2. Depois de completar o período de incubação, as células foram lavadas com PBS por 5 minutos e, em seguida, fixadas em paraformaldeído a 4\% durante 30 minutos, lavadas com água destilada, e coradas com vermelho de alizarina (2g em 100mL de água destilada) em pH 4,2 (A5533, Sigma), durante 5 a 10 minutos e cuidadosamente lavadas com PBS.

b) Diferenciação das CTmTA em células adipogênicas: A técnica para diferenciação adipogênica de cultura de CTm de rato Lewis foi padronizada a partir de diferentes protocolos testados em nosso laboratório. As células foram extraídas do Tecido adiposo como descrito anteriormente, colocadas em placas de 6 poços na concentração de $5 \times 10^{3}$ células por poço e mantidas em meio de crescimento DMEM-low glicose mais SFB a 10\%, acrescido de GlutaMax-I $(200 \mathrm{mM})$ e Gentamicina $(10 \mathrm{mg} / \mathrm{mL})$, por 4 dias até atingirem a confluência de 80\%. A partir daí adicionou-se o meio de diferenciação STEMPRO® AdipocyteDifferentiation Basal Medium e STEMPROß AdipogenesisSupplement a uma concentração final de $1 x$, além de $5 \mu \mathrm{g} / \mathrm{mL}$ de Gentamicina. As trocas do meio foram realizadas a cada três dias, pelo período de 14 dias. Depois de completado o período de incubação, as células foram fixadas com formalina $4 \%$ por 30 minutos e lavadas com PBS. 
Posteriormente as células foram incubadas por 10 minutos com Oil Red 0,5\% (Sigma-Aldrich, Saint Louis, EUA) para coloração. Após lavagem com PBSforam observados ao microscópio a presença de vacúolos lipídicos corados em vermelho.

c) Diferenciação das CTmTA em células condrogênicas: A diferenciação condrogênica das CTmTA ocorreu de forma semelhante a adipogênica. Uma concentração de $5 \times 10^{3}$ de células colocadas em placas de 6 poços e mantidas em meio de crescimento DMEM-low glicose mais SFB a 10\%, acrescido de GlutaMax-I (2mM) e Gentamicina $(10 \mathrm{mg} / \mathrm{mL})$, por 4 dias. Ao atingirem a confluência de $80 \%$, o meio de cultura foi substituído por um meio de diferenciação STEMPRO® Condrocyte Differentiation Basal Medium (1X), STEMPRO® Chondrogenesis Supplement (1X) e Gentamicina (10mg/mL). As trocas do meio foram feitas a cada 3 dias, pelo período de 14 dias.

Após o período de incubação, as células foram fixadas com formalina 4\% por 30 minutos e lavadas com PBS. Posteriormente as células foram incubadas por 10 minutos com Safranina (Sigma-Aldrich, Saint Louis, EUA) para coloração. Após lavagem com PBS foram observados ao microscópio a presença de vacúolos lipídicos corados em vermelho. 


\subsection{Infusão de CTmTA no órgão alvo}

Foram realizados experimentos para padronizar a técnica de inoculação das CTmTA no espaço subcapsular renal, a fim de proporcionar um número maior de células no órgão alvo. Deste modo, foram inoculadas CTmTAmantidas em PBS a uma temperatura de $4^{\circ} \mathrm{C}$ em 15 ratos Lewis machos, pesando entre $280 \mathrm{e} 350 \mathrm{~g}$, submetidos ao transplante renal unilateral ortotópico. Com a ajuda de um microscópio cirúrgico, um pequeno corte foirealizado na capsula renal próximo à região do Hilo renal, proporcionandoum acesso a região subcapsular. Com a ajuda de um cateter de $26 \mathrm{G}$ as células serão introduzidas lentamentena região preservando a estrutura da capsula e do parênquima renal.

\subsection{Análise Estatística}

A análise foi baseada na comparação de grupos, utilizando para os cálculos o software GraphPad Prism versão 6.01 (Graphpad Software, La Jolla, EUA). Inicialmente as diversas variáveis foram testadas para normalidade e então o teste ANOVA com pós-teste de Newman-Keuls foi aplicado. Em relação aos resultados de PCR em tempo real, após a obtenção dos valores de cycle trashold(CT) de cada amostra referente ao gene alvo, foi determinado a diferença de CT entre o gene constitutivo e o gene de interesse. Após, foi realizada a normalização destes valores sendo que para o resultado final é calculado o logaritmo da média dos valores normalizado. O desvio padrão foi 
calculado a partir dos valores normalizados de CT. Todos os resultados foram apresentados como média \pm erro padrão. A significância estatística foi considerada a partir do $p<0,05$. 


\section{RESULTADOS}

\subsection{Padronização do Modelo}

Durante o processo de padronização do modelo de Transplante renal, a maior dificuldade encontrada foi com relação às anastomoses vasculares. O desafio foi efetuar as suturas vasculares sem que houvesse extravasamento de sangue, tão pouco estenose dos vasos com consequente infarto do órgão.

Assim, após a realização de um piloto e análise dos resultados observados a seguir, estabeleceu-se que para o desenvolvimento do transplante renal, seria aplicada a técnica de anastomoses vasculares do tipo termino-terminal.

\subsubsection{Piloto1: Padronização da técnica cirúrgica}

Os primeiros transplantes realizados consistiram na execução da técnica de anastomose termino-lateral com um "patch" de aorta e veia cava inferior do doador que foram então suturadas na aorta e veia cava do receptor. Para tanto, um clamp vascular foi utilizado na região supra-renal da aorta para impedir o fluxo sanguíneo para o órgão. Após o restabelecimento do fluxo vascular, uma estenose venosa na região das anastomoses foi observada em cerca de $90 \%$ dos animais submetidos ao transplante (Figura 1 A). Ainda, pontos de trombose intra-renais foram observados na porção posterior do rim transplantado (Figura 1B)

Após um período superior a 30 minutos sem o reestabelecimento do fluxo sanguíneo para a região dos membros inferiores do animal devido ao clamp na porção da aorta abdominal, os animais operados apresentaram sinais de 
paraplegiasendo assim encaminhados para a eutanásia. Deste modo, após inúmeras tentativas, optou-se por utilizar a técnica de sutura do tipo terminoterminal que apesar de mais segura mostrava-se tecnicamente mais desafiadora.
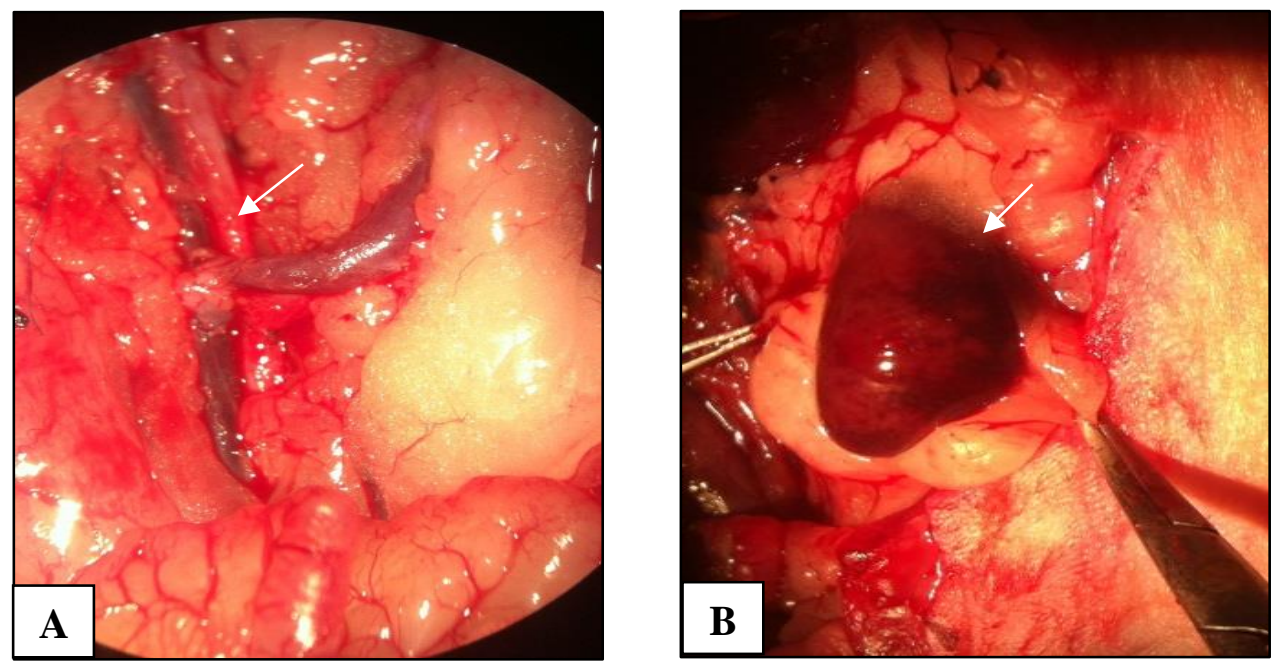

Figura 1. (A). Estenose venosa após o reestabelecimento do fluxo sanguíneo (seta). (B) Aspecto trombótico do rim transplantado após estabelecimento do fluxo sanguíneo (seta).

\subsection{Modelo Experimental de Transplante Renal}

Após o estabelecimento da melhor metodologia a ser aplicada, inúmeras tentativas de anastomose vascular foram realizadas a fim de aprimorar a qualidade das suturas bem como minimizar o tempo cirúrgico. Sendo assim após um exaustivo período, o tempo cirúrgico passou de 55 minutos para 30 minutos, sendo este um tempo adequado segundo a literatura (Daniller et al.,1968) 
Com a precisa realização das anastomoses vasculares e o tempo cirúrgico adequado, a próxima etapa foi a padronização da anastomose ureteral.

O ureter de rato apresenta um diâmetro aproximado de 1,5 a 2,0mm em condições fisiológicas normais. Entretanto, com a segmentação do ureter em sua porção medial, uma significativa diminuição do diâmetro é observada, apresentando desta forma um diâmetro de aproximadamente 0,5 a 1,0mm.

Assim, a sutura termino-terminal do ureter representou mais um desafio técnico a ser padronizado. Após um longo período de treinamento, o transplante renal ortotópico em ratos foi padronizado com sucesso (Figura 4) 

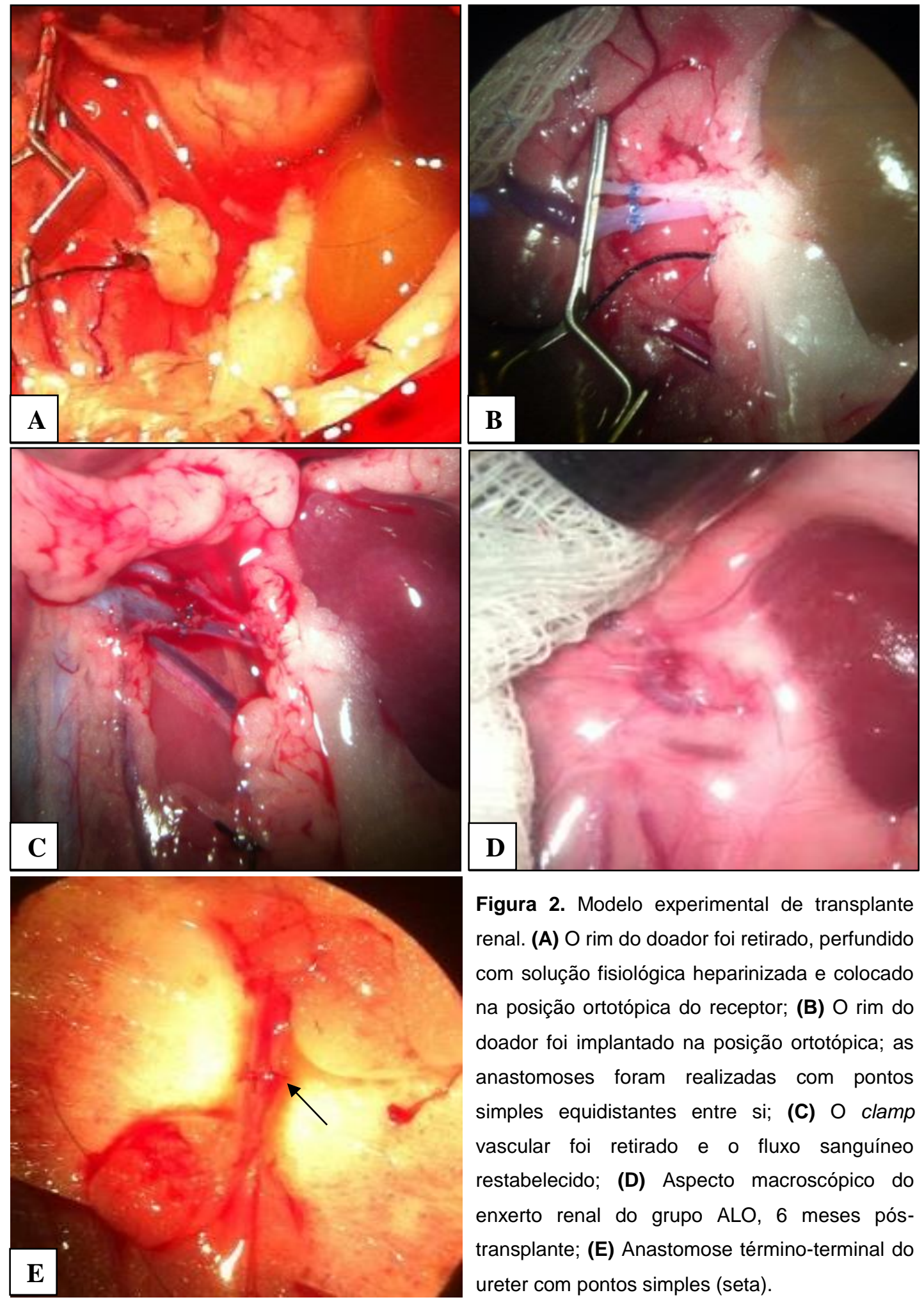

Figura 2. Modelo experimental de transplante renal. (A) O rim do doador foi retirado, perfundido com solução fisiológica heparinizada e colocado na posição ortotópica do receptor; (B) O rim do doador foi implantado na posição ortotópica; as anastomoses foram realizadas com pontos simples equidistantes entre si; (C) O clamp vascular foi retirado e o fluxo sanguíneo restabelecido; (D) Aspecto macroscópico do enxerto renal do grupo ALO, 6 meses póstransplante; (E) Anastomose término-terminal do ureter com pontos simples (seta). 
Vale ressaltar que devido ao alto grau de dificuldade na dissecção do vaso e na confecção das anastomoses, para a padronização da técnica cirúrgica de transplante de renal é necessário ter um laboratório bem estruturado com equipamentos e instrumental cirúrgico especializado. 


\subsubsection{Tempo total de anastomoses}

A análise do tempo de anastomose em todos os grupos experimentais se manteve estável, não apresentando diferenças estatísticas (Tabela 3; Figura 9).

Tabela 3. Tempo total de anastomose nos animais receptores do transplante renal experimental

\begin{tabular}{lc} 
Grupos & $\begin{array}{c}\text { Tempo de } \\
\text { anastomose } \\
(\mathrm{min})\end{array}$ \\
\hline ISO $(\mathrm{n}=6)$ & $30 \pm 2$ \\
\hline ALO $(\mathrm{n}=6)$ & $34 \pm 1$ \\
\hline ALO+CTmTA $(\mathrm{n}=6)$ & $35 \pm 4$ \\
\hline
\end{tabular}

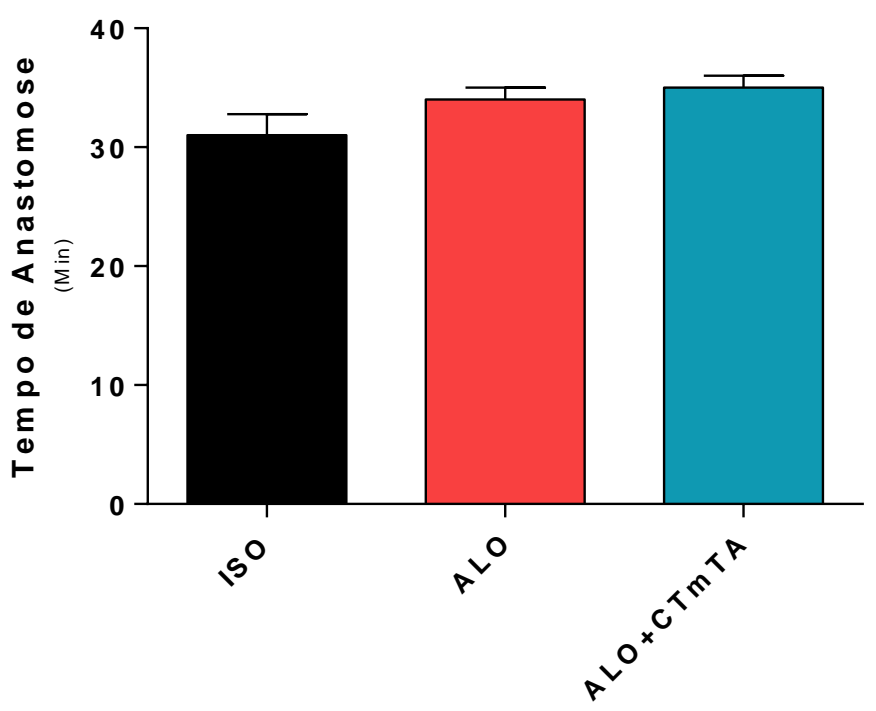

Figura 3. Gráfico representativo do tempo total de anastomose nos animais receptores do transplante renal experimental 


\subsubsection{Tempo de Isquemia Fria}

Não foram observadas diferenças estatísticas no tempo de isquemia fria entre os grupos experimentais (Tabela 4; Figura 10).

Tabela 4. Tempo total de isquemia renal a frio durante o processo de confecção das anastomoses vasculares

\begin{tabular}{lc} 
Grupos & $\begin{array}{c}\text { Tempo de } \\
\text { Isquemia fria } \\
(\mathrm{min})\end{array}$ \\
\hline ISO $(n=6)$ & $35 \pm 1$ \\
\hline ALO $(n=6)$ & $38 \pm 1$ \\
\hline ALO+CTmTA $(n=6)$ & $36 \pm 1$ \\
\hline
\end{tabular}

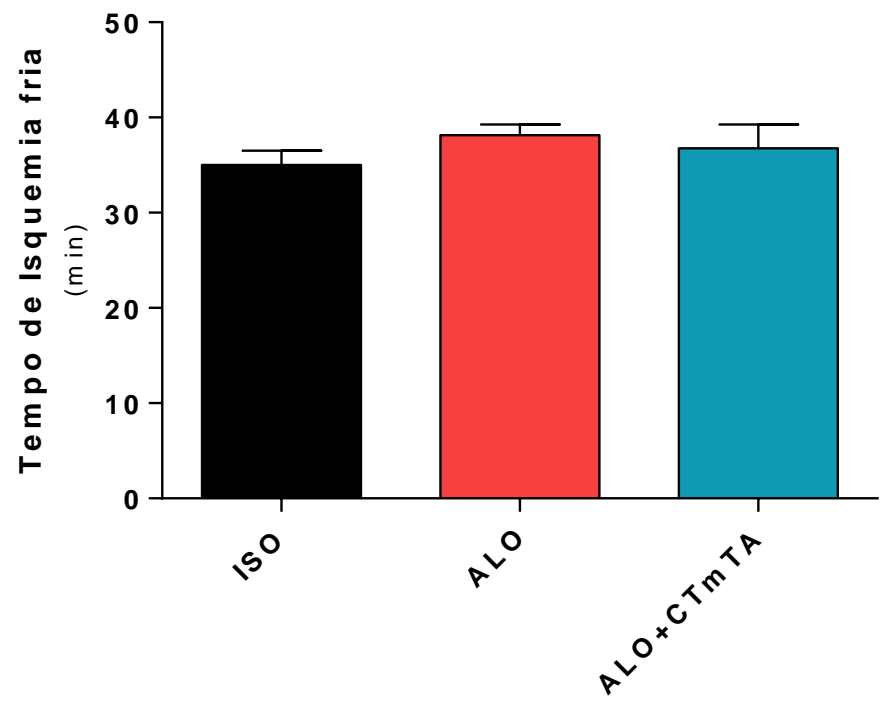

Figura 4. Gráfico representativo do tempo total de isquemia renal fria 


\subsubsection{Peso renal}

Não houve diferença estatística entre os grupos ISO, ALO e ALO+CTmTA, com relação ao peso renal (Tabela 6; Figura 12).

Tabela 5. Média do peso renal 6 meses pós-transplante

\begin{tabular}{lc} 
Grupos & $\begin{array}{c}\text { Peso renal } \\
(\mathrm{g})\end{array}$ \\
\hline ISO $(n=6)$ & $1,92 \pm 0,25$ \\
\hline ALO $(n=6)$ & $2,07 \pm 0,18$ \\
\hline ALO+CTmTA $(n=6)$ & $2,24 \pm 0,12$ \\
\hline
\end{tabular}

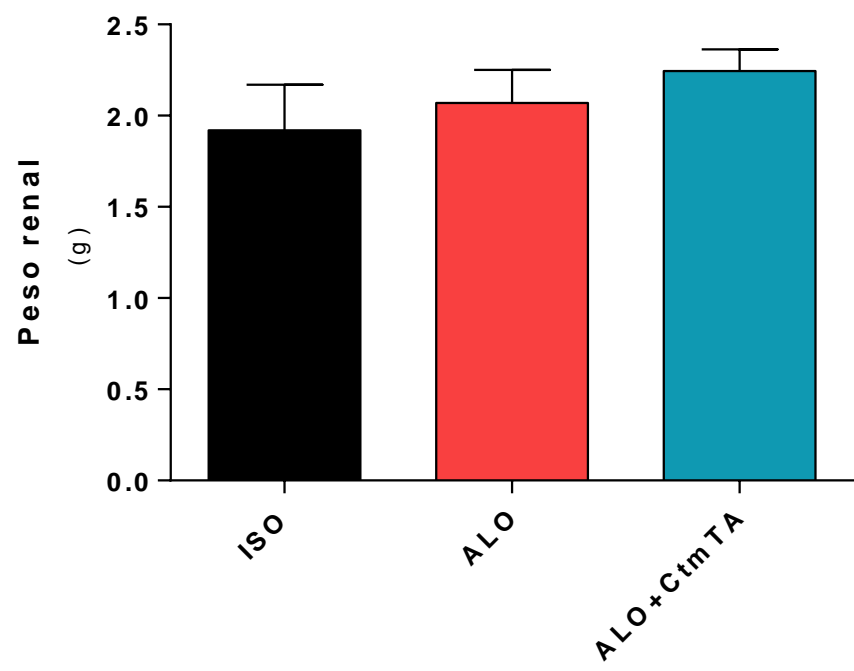

Figura 5. Gráfico representativo da média do peso renal no 6 meses pós-transplante em todos os grupos experimentais 


\subsection{Isolamento e Cultura de CTmTA}

Após o Isolamento de células do tecido adiposo gonadal, as células foram colocadas em cultura e 2 dias após observou-se o desenvolvimento de uma cultura heterogênea, composta por células arredondadas, não aderentes e micelas lipídicas no sobrenadante da cultura. As trocas do meio de cultura propiciaram a remoção das células não aderentes e das micelas lipídicas. A partir do décimo dia, a população celular estava mais homogênea, com predominância das células aderentes de morfologia fibroblastóide, organizadas em colônias. Mediante a visualização de $80 \%$ de confluência celular nas placas, as células foram tripsinizadas e novas subculturas foram estabelecida. Durante todo o período de cultivo, até a quinta passagem, as células aderentes mantiveram-se fenotipicamente estáveis, sem sinais de senescência (Figura 5
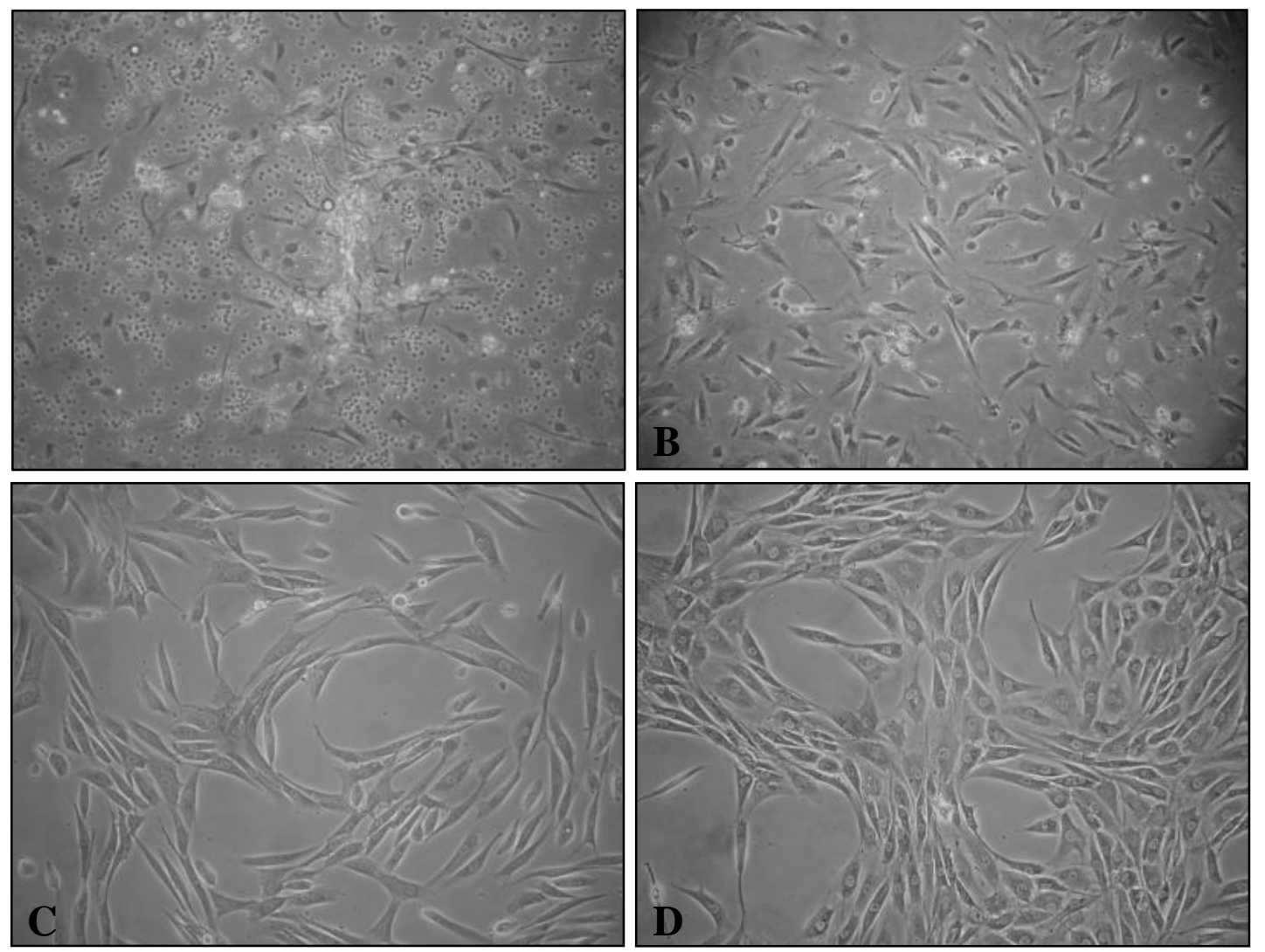


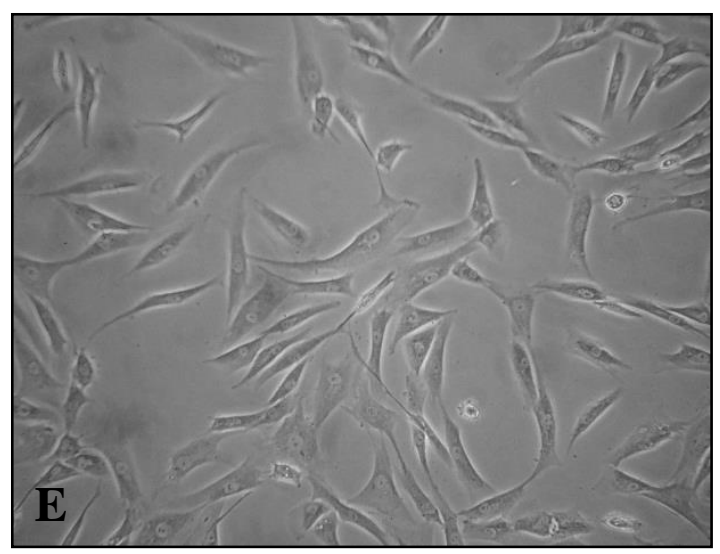

Figura 6. CTmTA de ratos Lewis nas passagens: (A) P0, (B) P1, (C) P4, (D) P5 e (E) P6 


\subsubsection{Citometria de Fluxo - Imunofenótipo mesenquimal}

Os marcadores de superfície positivos para CTm CD29, CD90, CD44 e CD105 bem como o marcador pam-leucocitário CD45 foram analisados por citometria de fluxo em culturas de CTmTA nas passagens 2, 4, 5 e 6 (Tabela 4), a fim de determinar o melhor fenótipo para a terapia celular (Figura 6). Além disso, foi analisada a expressão de MHC classe I e MHC classe II, na superfície celular.

Tabela 6. Porcentagem de marcação das CTmTA nas diferentes passagens

\begin{tabular}{lccccc}
\hline & \multicolumn{5}{c}{ GRUPOS } \\
\cline { 2 - 6 } PASSAGENS & CD29 & CD44 & CD90 & CD105 & CD45 \\
\hline P2(\%) & 70,1 & 0,9 & 28,2 & 0,9 & 0,9 \\
P4(\%) & 94,7 & 22,5 & 88,4 & 22,7 & 3,2 \\
P5(\%) & 99,5 & 66,5 & 83,1 & 98,6 & 4,5 \\
P6(\%) & 50,2 & 43,5 & 87,0 & 78,4 & 5,6 \\
\hline
\end{tabular}



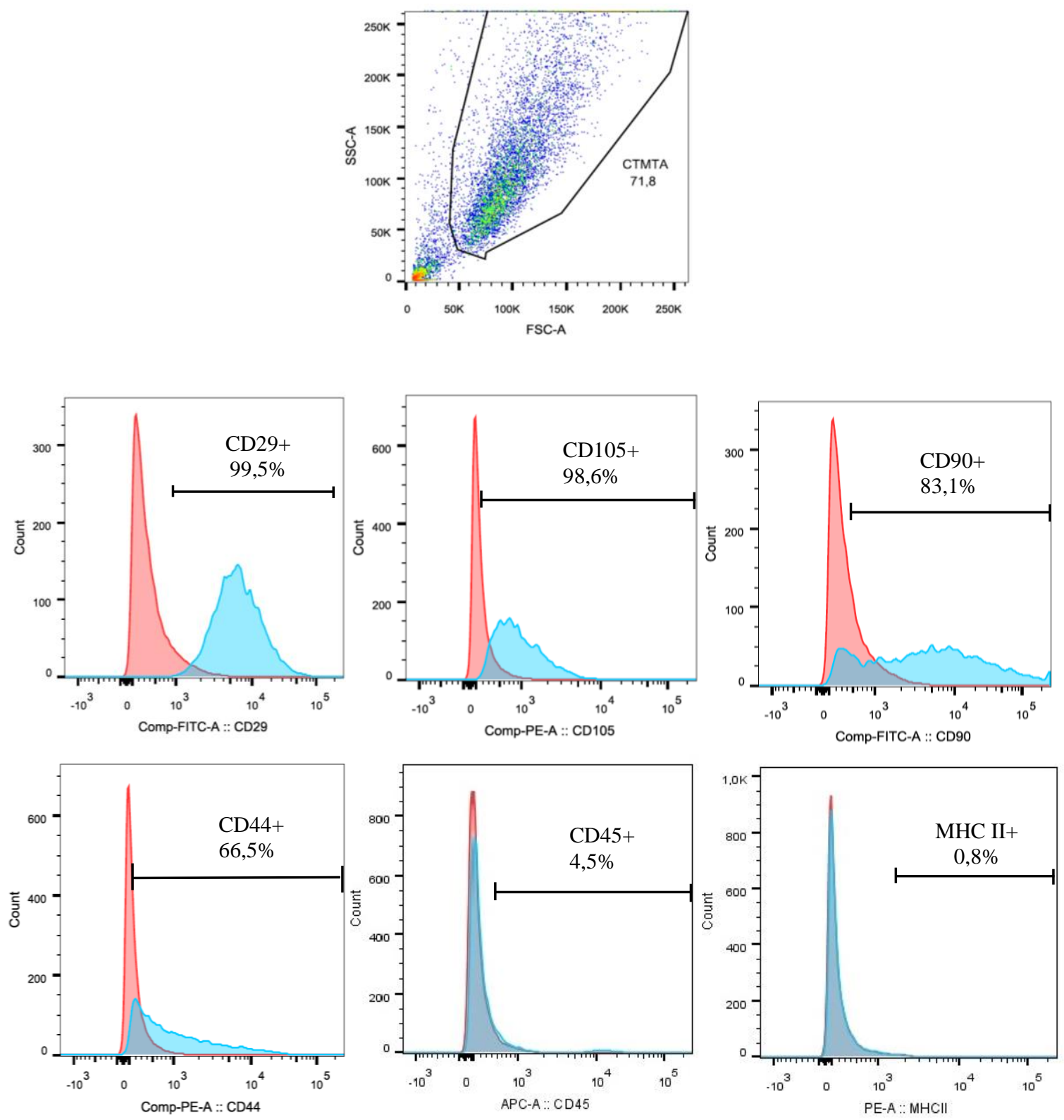

Figura 7: Citometria de Fluxo para fenótipo mesenquimal das CTmTA na $5^{\circ}$ passagem. Marcadores positivos CD29, CD105, CD90 e CD44 e marcadores negativos CD45 além de MHC II 


\subsubsection{Diferenciação}

Sob condições específicas de cultivo, as CTmTA foram diferenciadas nas linhagens adipogênica, com presença de gotículas de gordura no citoplasma, condrogênica com presença de deposição de matriz extracelular e osteogênica com precipitação de cálcio citoplamático.
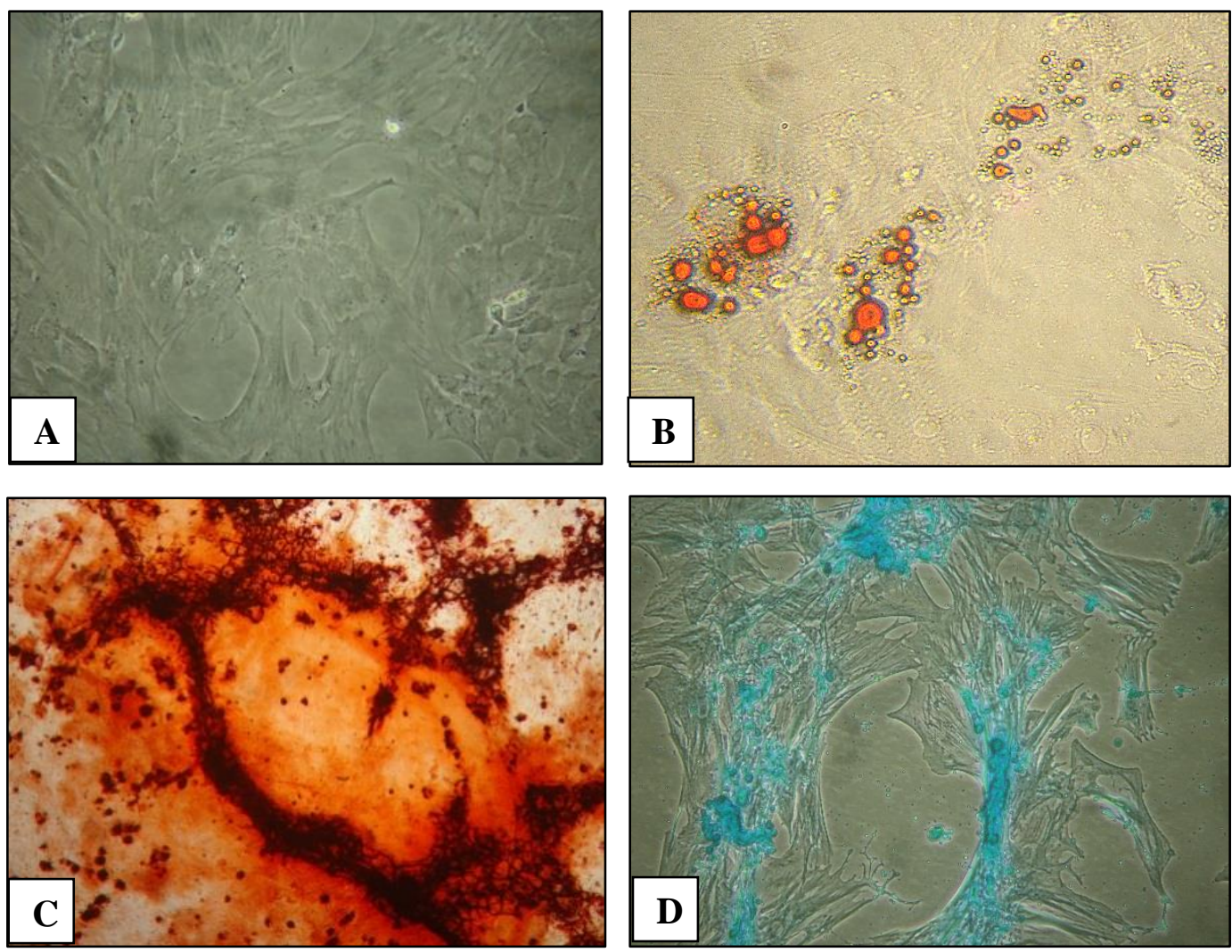

Figura 8: Diferenciação in vitro de culturas de CTmTA na 5ำ passagem. Em A) Células cultivadas em meio DMEM baixa glicose $+10 \%$ SBF; B) Células cultivadas em meio indutor adipogênico, e coradas em corante Oil Red, evidenciando o acúmulo de gotículas lipidícas; C) Células cultivadas em meio indutor osteogênico, e coradas em Vermelho de Alizarina, que mostra os depósitos de Cálcio nas células. D) Células cultivadas em meio indutor condrogênico, coradas com Safranina 


\subsubsection{Imunofluorescência - imunofenótipo mesenquimal}

A análise da imunofenotipagem por Imunofluorescência foi realizada para confirmar os resultados obtidos na citometria de fluxo. Os marcadores positivos CD44, CD90, CD146, CD73 e STRO-1 além dos marcadores negativos CD19, CD14 e CD45, foram utilizados para determinar o imunofenótipo das células. Deste modo, após as análises pudemos observar uma clara marcação de todos os marcadores considerados positivos, bem como uma ausência de marcação nos fragmentos encubados com anticorpos sabidamente negativos (Figura 8).
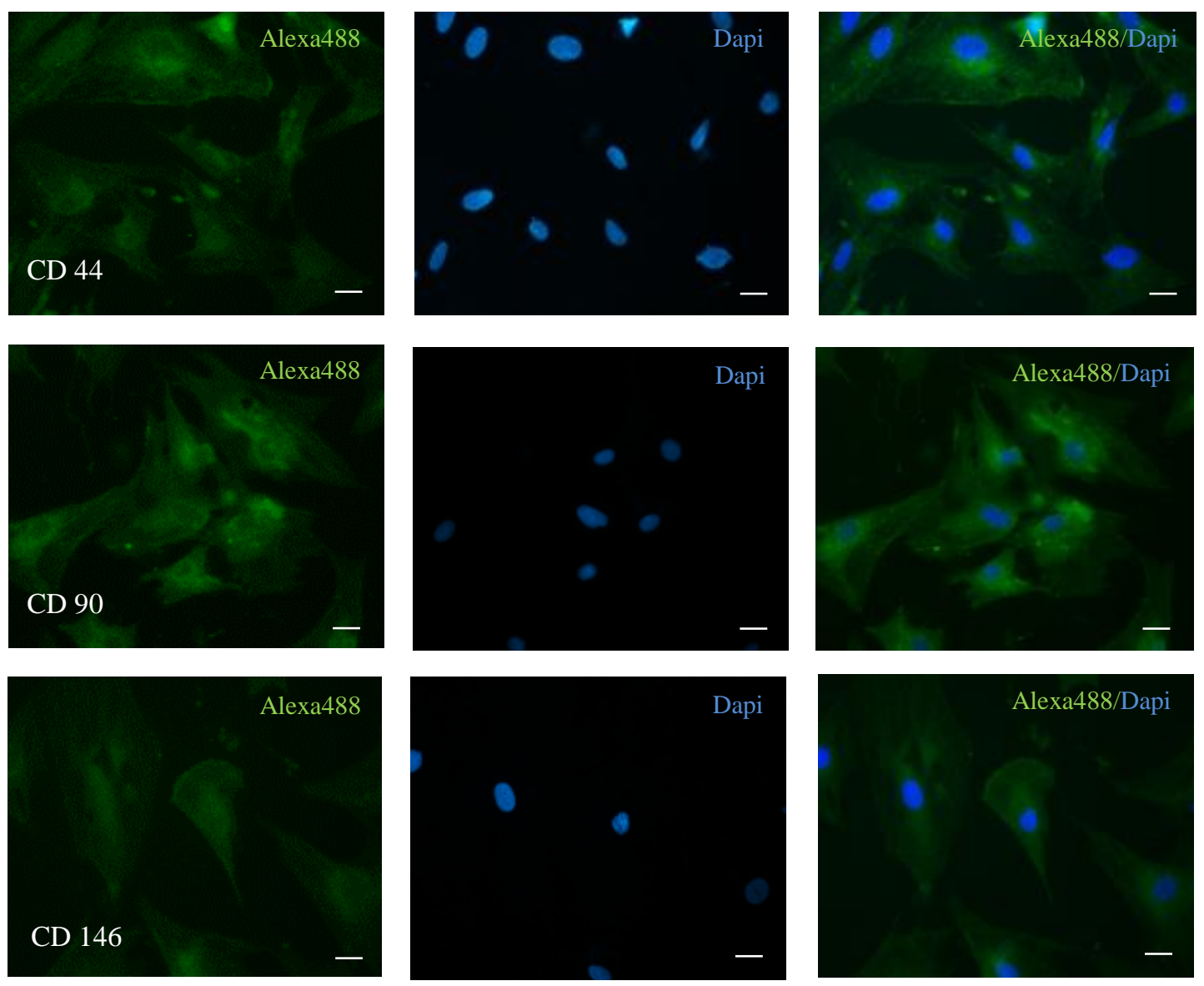

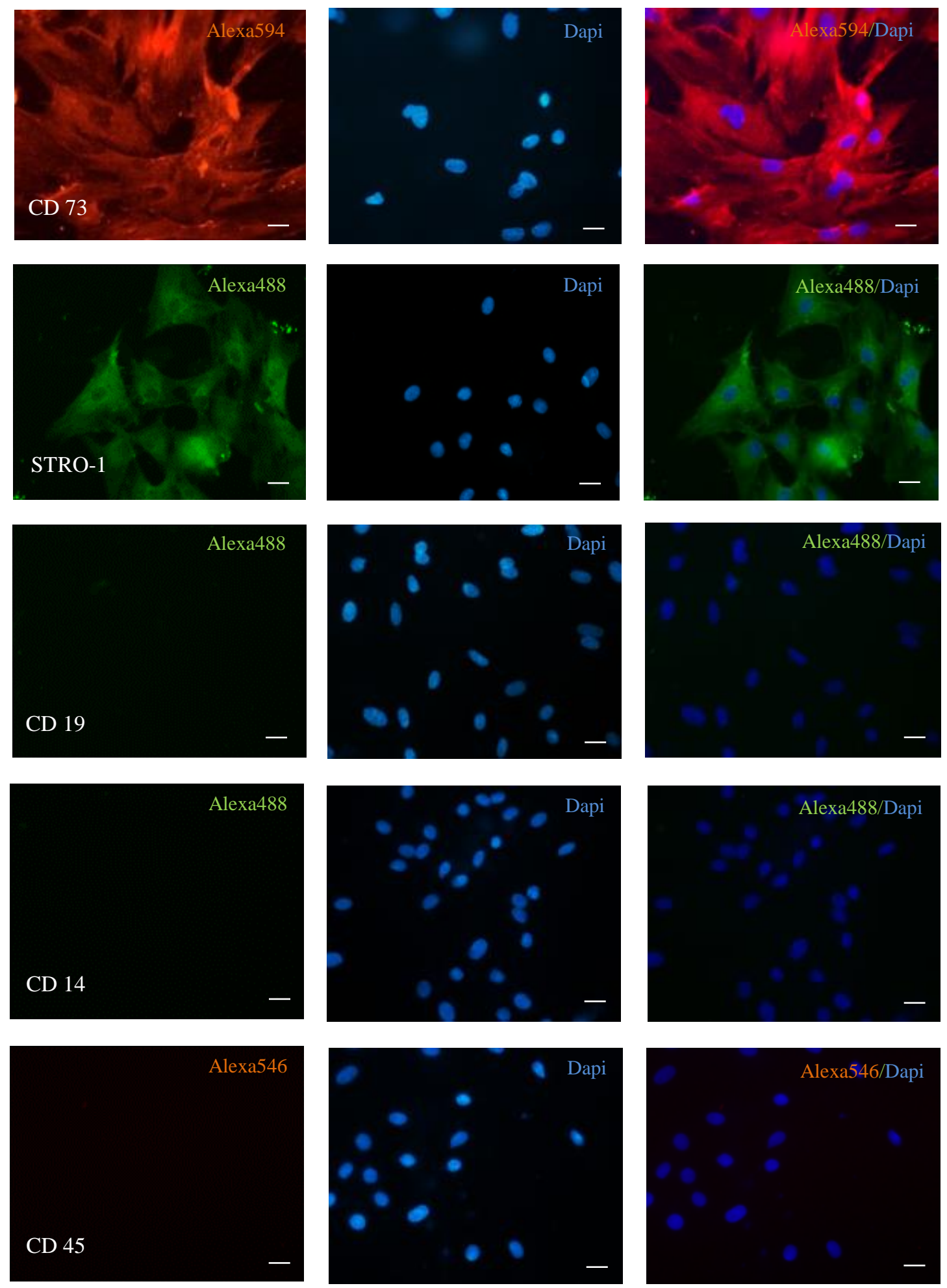

Figura 9: Imunofluorescência para marcadores positivos (CD44, CD90, CD146, CD73 e STRO1) e negativos (CD19, CD14 e CD45) 


\subsubsection{Peso corpóreo}

Todos os animais apresentaram peso corpóreo semelhante no início do protocolo (média de $260 \mathrm{~g}$ na primeira semana). Entretanto, no $1^{0}$ mês póstransplante, houve diferença estatística entre os grupos ISO e o grupo ALO+CTmTA e 6 meses pós-transplante entre os grupos ISO e ALO. O tratamento com CTmTA não teve influência no ganho de peso em comparação aos animais do grupo ALO. O grupo ALO+CTmTA não apresentou recuperação do peso corpóreo em comparação ao grupo ALO no 6ำ mês pós-transplante (Tabela 5, Figura 11).

Tabela 7. Peso corpóreo dos diferentes grupos na semana 1 e nos meses 1,3 e 6 póstransplante

\begin{tabular}{|c|c|c|c|c|}
\hline Grupos & $\underset{(\mathrm{g})}{19 \text { Semana }}$ & $\begin{array}{c}\text { 19Mês } \\
\text { (g) }\end{array}$ & $\begin{array}{l}\text { 3Mês } \\
\text { (g) }\end{array}$ & $\begin{array}{c}\text { 69Mês } \\
\text { (g) }\end{array}$ \\
\hline ISO $(n=6)$ & $254 \pm 5$ & $275 \pm 13$ & $345 \pm 6$ & $405 \pm 2$ \\
\hline $\operatorname{ALO}(n=6)$ & $273 \pm 9$ & $294 \pm 10$ & $336 \pm 8$ & $380 \pm 17^{*}$ \\
\hline ALO+CTmTA $(n=6)$ & $263 \pm 7$ & $298 \pm 12^{*}$ & $358 \pm 14^{\#}$ & $377 \pm 15^{\star}$ \\
\hline
\end{tabular}

${ }^{*} p<0,05$ vs. ISO e \# $p<0,05$ vs. ALO

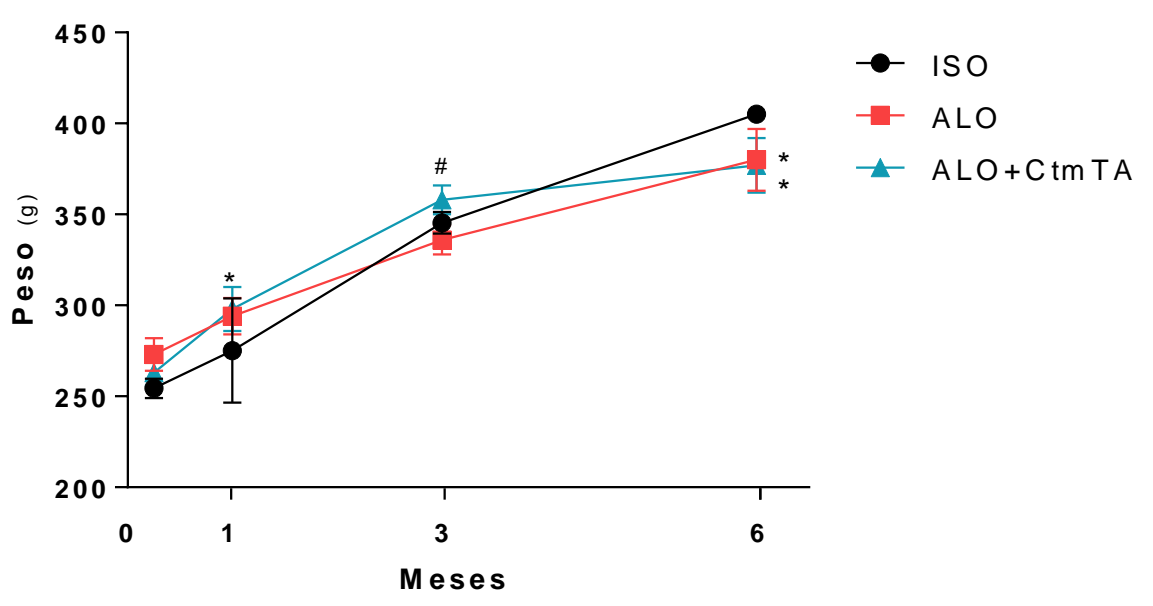

Figura 10. Gráfico representativo dos pesos corpóreo dos animais transplantados na semana 1 e nos meses 1,3 e 6 pós-transplante. ${ }^{*} p<0,05$ vs. ISO e \# $p<0,05$ vs. ALO 


\subsubsection{Pressão Arterial}

A pressão arterial nos animais foi avaliada pela pressão caudal. A pressão arterial do grupo ISO se manteve normal. No entanto, os animais do grupo ALO apresentaram um aumento significativo da pressão arterial em comparação ao grupo ISO. O tratamento com CTmTA, impediu de forma significativa o aumento da pressão arterial no grupo ALO+CTmTA (Tabela 8, Figura 13).

Tabela 8. Peso renal no momento do sacrifício, 6 meses pós-transplante

\begin{tabular}{|c|c|c|c|c|}
\hline Grupos & $\begin{array}{c}\text { 1ㅇomana } \\
(\mathrm{mmHg})\end{array}$ & $\begin{array}{l}\text { 19Mês } \\
(\mathrm{mmHg})\end{array}$ & $\begin{array}{l}\text { 3oMês } \\
\text { (mmHg) }\end{array}$ & $\begin{array}{l}\text { 6\%Mês } \\
\text { (mmHg) }\end{array}$ \\
\hline ISO $(n=6)$ & $130 \pm 3$ & $131 \pm 2$ & $139 \pm 2$ & $144 \pm 1$ \\
\hline ALO $(n=6)$ & $132 \pm 2$ & $134 \pm 4$ & $153 \pm 4^{\star}$ & $166 \pm 1^{*}$ \\
\hline ALO+CTmTA $(n=6)$ & $131 \pm 1$ & $138 \pm 2^{*}$ & $142 \pm 3^{\#}$ & $147 \pm 1^{\#}$ \\
\hline
\end{tabular}

${ }^{*} p<0,05$ vs. ISO e \# $p<0,05$ vs. ALO

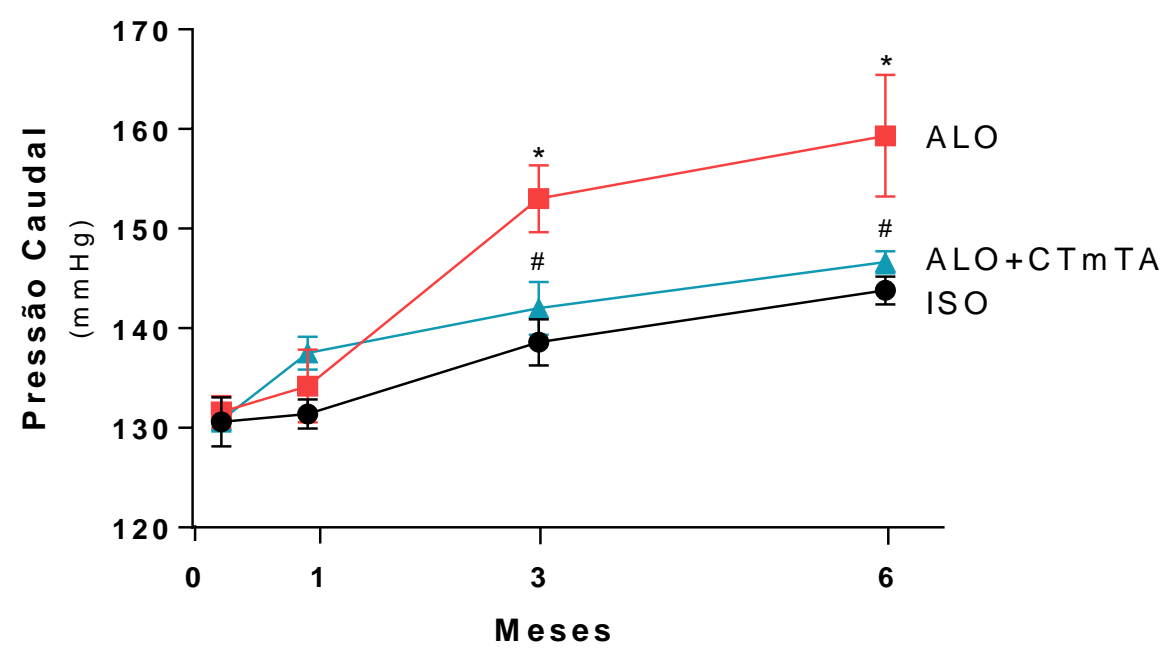

Figura 11. Pressão caudal no decorrer dos 6 meses de estudos dos três grupos experimentais. ${ }^{*} p<0,05$ vs. ISO e \# $p<0,05$ vs. ALO 


\subsubsection{Mortalidade}

O número de óbitos no grupo ISO foi de 4 animais, enquanto que no grupo ALO foi de 3 animais. O tratamento com CTmTA impediu de forma significativa a mortalidade no grupo ALO+CTmTA (Figura 14).

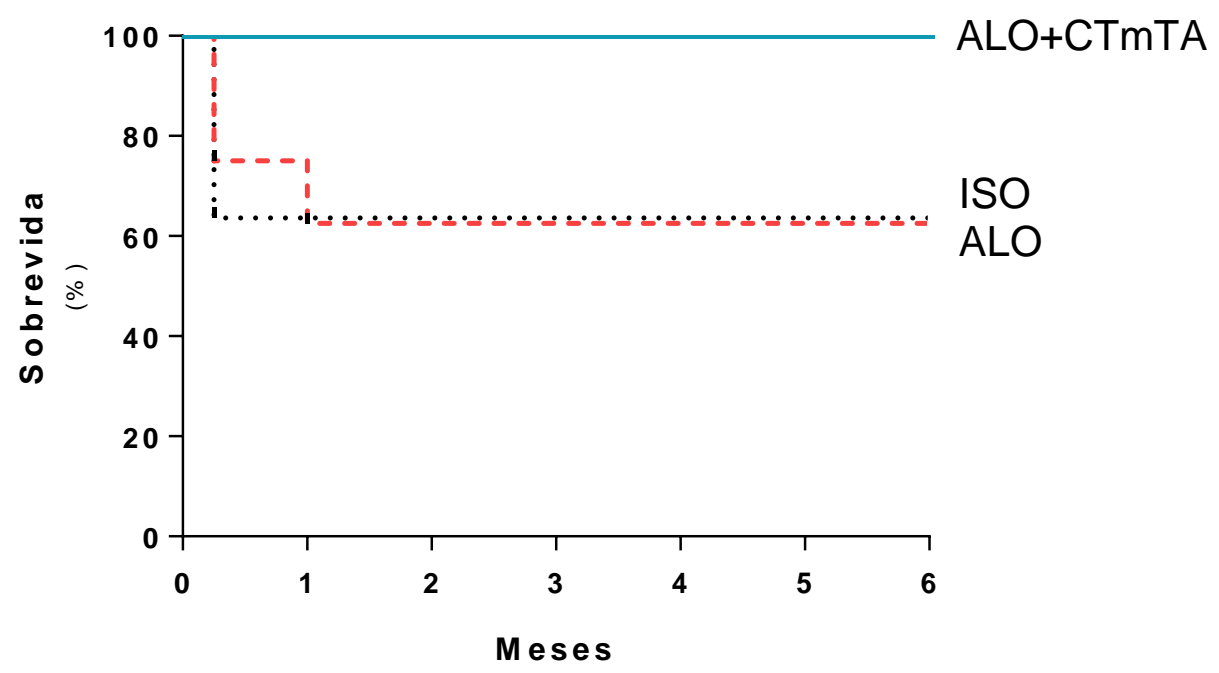

Figura 12. Sobrevida dos animais submetidos ao transplante renal durante o período de 6 meses 


\subsection{Bioquímica}

\subsubsection{Ureia sérica}

Como esperado, os animais do grupo ISO apresentaram níveis de uréia dentro da normalidade. O grupo ALO apresentou um aumento significativo com relação ao grupo ISO. O tratamento com CTmTA impediu o aumento da uréia sérica de forma significativa (Tabela 9; Figura 14).

Tabela 9. Ureia sérica 6 meses pós-transplante. * $p<0,05$ vs. ISO e \# p<0,05 vs. ALO

\begin{tabular}{lc}
\hline Grupos & $\begin{array}{c}\text { Ureia } \\
(\mathrm{mg} / \mathrm{dL})\end{array}$ \\
\hline ISO $(\mathrm{n}=6)$ & $50 \pm 1,3$ \\
\hline ALO $(\mathrm{n}=6)$ & $70 \pm 8,3^{\star}$ \\
\hline ALO+CTmTA $(\mathrm{n}=6)$ & $43 \pm 1,1^{\#}$ \\
\hline
\end{tabular}

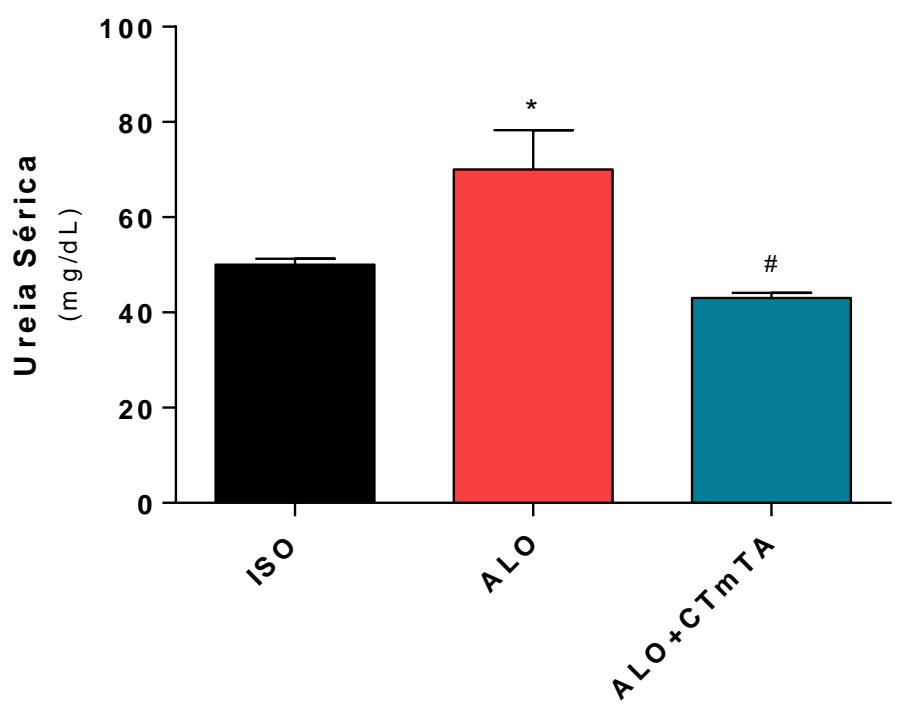

Figura 13. Ureia sérica dos grupos experimentais 6 meses pós-transplante. * $p<0,05$ vs. ISO e $\# p<0,05$ vs. ALO 


\subsubsection{Creatinina sérica}

A creatinina sérica foi normal no grupo ISO. O grupo ALO apresentou um aumento significativo dos níveis séricos de creatinina em comparação ao grupo ISO. O grupo tratado com CTmTA reduziu de forma significante os níveis de creatinina séricas quanto comparados ao grupo ALO (Tabela 10, figura 15).

Tabela 10. Creatinina sérica 6 mesespós-transplante. ${ }^{*} p<0,05$ vs. ISO e \# $p<0,05$ vs. ALO

\begin{tabular}{lc} 
Grupos & $\begin{array}{c}\text { Creatinina } \\
(\mathrm{mg} / \mathrm{dL})\end{array}$ \\
\hline ISO $(n=6)$ & $0,5 \pm 0,2$ \\
\hline ALO $(n=6)$ & $1,6 \pm 0,7^{\star}$ \\
\hline ALO+CTmTA $(n=6)$ & $0,5 \pm 0,1^{\#}$ \\
\hline
\end{tabular}

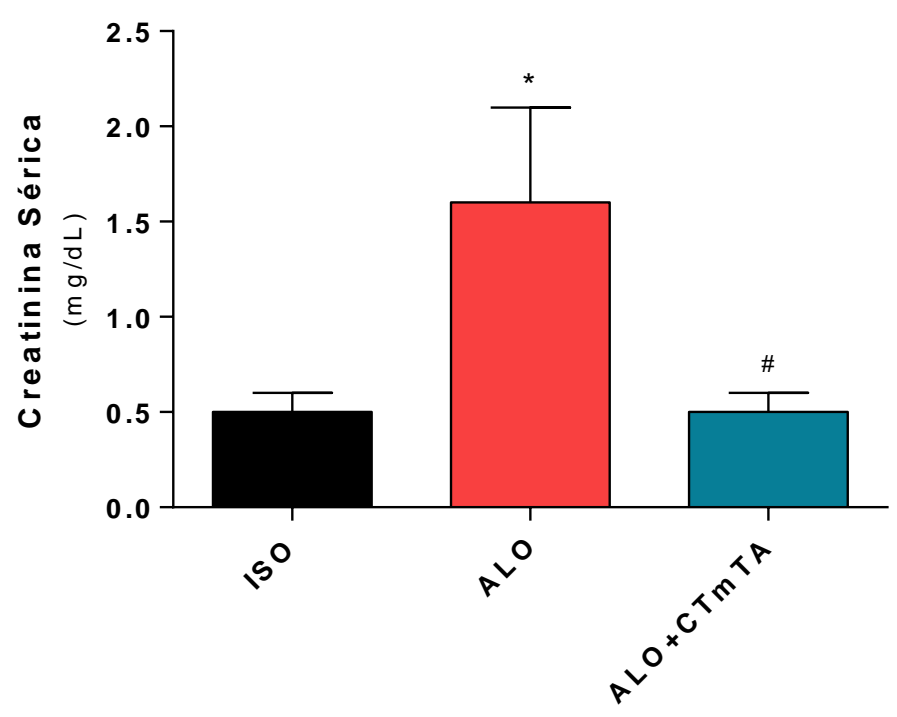

Figura 14. Creatinina sérica dos grupos experimentais 6 meses pós-transplante. * $p<0,05$ vs. ISO e \# $p<0,05$ vs. ALO 


\subsubsection{Clearance de Creatinina}

Para a determinação da taxa de filtração glomerular estimado foi aplicada a fórmula de crockft gaud. O grupo ISO não apresentou alterações. O grupo ALO apresentou um declínio da taxa de filtração glomerular em comparação ao grupo ISO. O tratamento com CTmTA foi eficiente em prevenir a diminuição do clearance de creatinina comparado ao grupo ALO (Tabela 11, figura 17).

Tabela 11. Clearance de creatinina 6 meses pós-transplante. ${ }^{*} p<0,05$ vs. ISO e \# $p<0,05$ vs. ALO

\begin{tabular}{lc} 
Grupos & $\begin{array}{c}\text { Clearance } \\
\text { Creatinina } \\
(\mathrm{m} / \mathrm{min})\end{array}$ \\
\hline ISO $(n=6)$ & $1,30 \pm 0,1$ \\
\hline ALO $(n=6)$ & $0,7 \pm 0,2^{\star}$ \\
\hline ALO+CTmTA $(n=6)$ & $1,5 \pm 0,1^{\#}$ \\
\hline
\end{tabular}

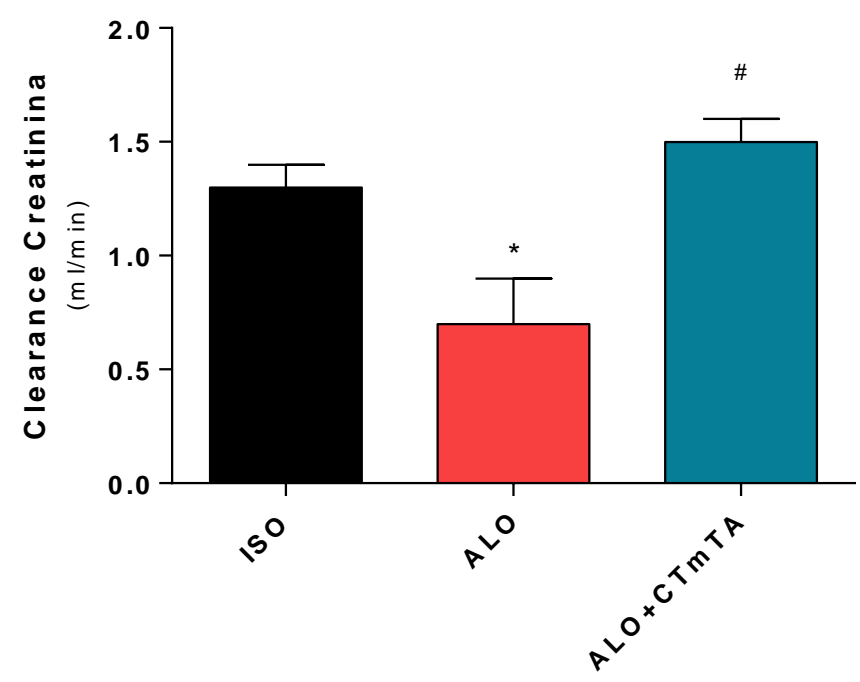

Figura 15. Clearance de creatinina dos grupos experimentais 6 meses pós-transplante. * $p<0$, 05 vs. ISO e \# $p<0,05$ vs. ALO 


\subsubsection{Proteinúria}

Os animais do grupo ISO apresentaram proteinúria normal. O grupo ALO apresentou um elevado aumento na proteinúria com relação ao grupo ISO. O tratamento com CTmTA foi eficiente em prevenir o aumento na proteinúira de forma eficiente (Tabela 12; Figura 18).

Tabela 12. Proteinúria 6 meses pós-transplante

\begin{tabular}{lc} 
Grupos & $\begin{array}{c}\text { Proteinúria } \\
(\mathrm{mg} / 24 \mathrm{~h})\end{array}$ \\
\hline ISO $(\mathrm{n}=6)$ & $80 \pm 7$ \\
\hline ALO $(\mathrm{n}=6)$ & $167 \pm 14^{\star}$ \\
\hline ALO+CTmTA $(\mathrm{n}=6)$ & $117 \pm 8^{\star} \#$ \\
\hline
\end{tabular}

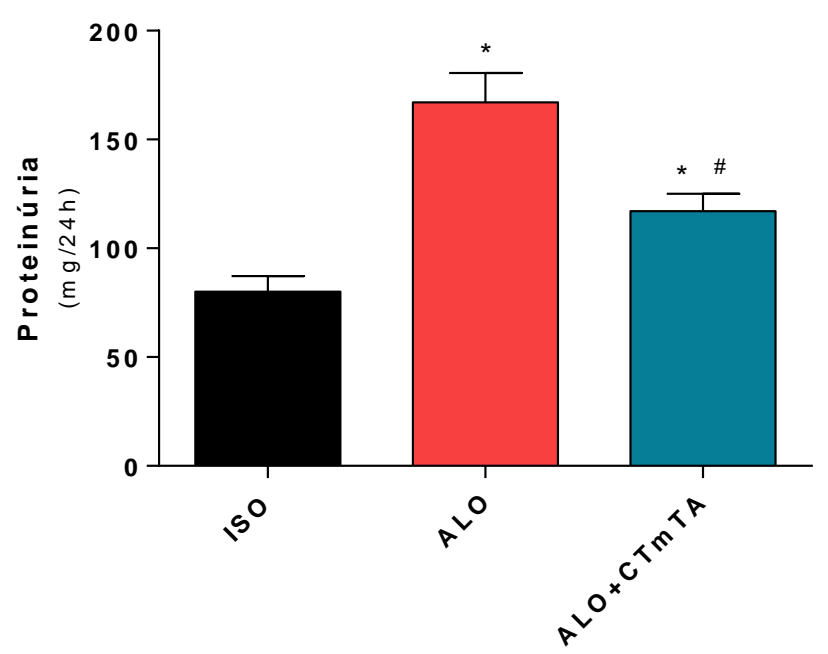

Figura 16. Proteinúria dos grupos experimentais 6 meses pós-transplante. * $p<0,05$ vs. ISO e $\# p<0,05$ vs. ALO 


\subsubsection{Fração de excreção de Sódio e Potássio}

A fração de excreção de sódio no grupo ISO não se apresentou alterada. Contudo o grupo ALO apresentou um aumento significativo na fração de excreção de Sódio comparado ao grupo ISO. O grupo tratado com CTmTA apresentou uma melhora significativa em relação ao grupo ALO. Quanto a Fração de excreção de potássio, não houve diferença significativa entre os grupos ISO, ALO e ALO+CTmTA. No entanto, uma pronunciada tendência de aumento é observada no grupo ALO em comparação aos grupos ISO e ALO+CTmTA (Tabela 13; Figura 19).

Tabela 13. Fração de excreção de sódio e Potássio 6 meses pós-transplante. * $p<0,05$ vs. ISO e \# $\mathrm{p}<0,05$ vs. ALO

\begin{tabular}{lcc} 
Grupos & $\begin{array}{c}\mathrm{FeNa}^{+} \\
(\%)\end{array}$ & $\begin{array}{c}\mathrm{FeK}^{+} \\
(\%)\end{array}$ \\
\hline ISO $(\mathrm{n}=6)$ & $0,3 \pm 0,0$ & $42 \pm 5$ \\
\hline ALO $(\mathrm{n}=6)$ & $1,2 \pm 0,5^{\star}$ & $118 \pm 61$ \\
\hline ALO+CTmTA $(n=6)$ & $0,3 \pm 0,0^{\#}$ & $33 \pm 6$ \\
\hline
\end{tabular}
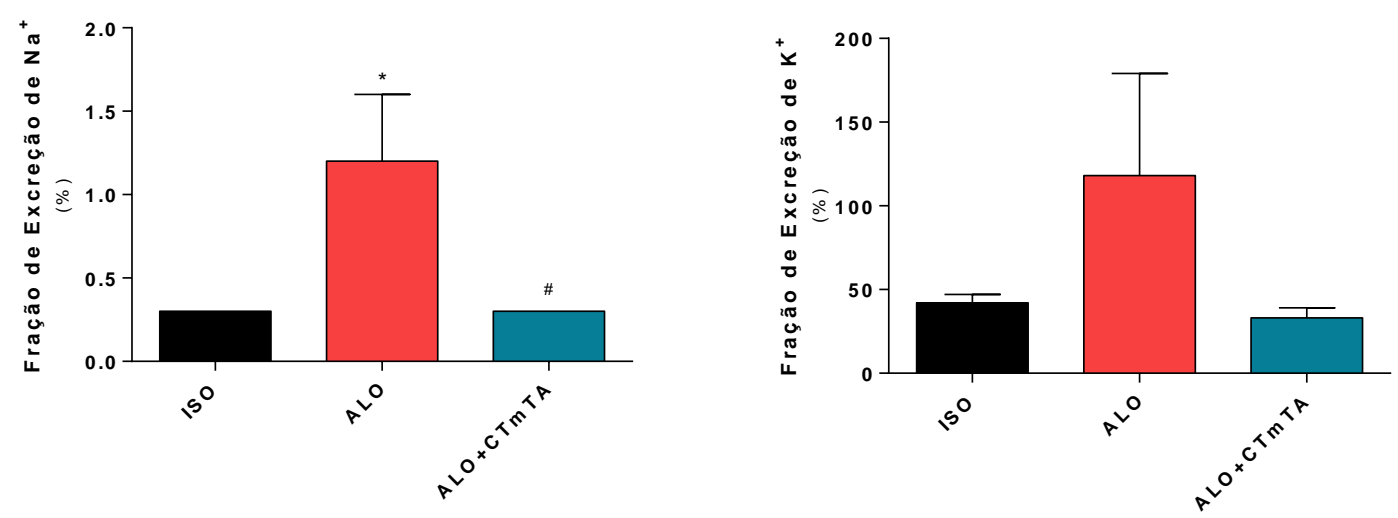

Figura 17. Fração de Excreção de Sódio e Potássio dos grupos experimentais 6 meses póstransplante. ${ }^{*} p<0,05$ vs. ISO e \# $p<0,05$ vs. ALO 


\subsection{Histologia Renal}

A análise do grupo ISO (figura 20A) mostrou um tecido íntegro, sem alterações histológicas compatíveis com rejeição. No caso do grupo ALO (figura 20B) verifica-se a presença de fibrose intersticial acentuada. Não foi observado aumento de fibrose nos compartimentos glomerulares e vasculares. No grupo ALO+CTmTA (figura 20C) a porcentagem de tecido acometido por fibrose foi significativamente menos que no grupo ALO.
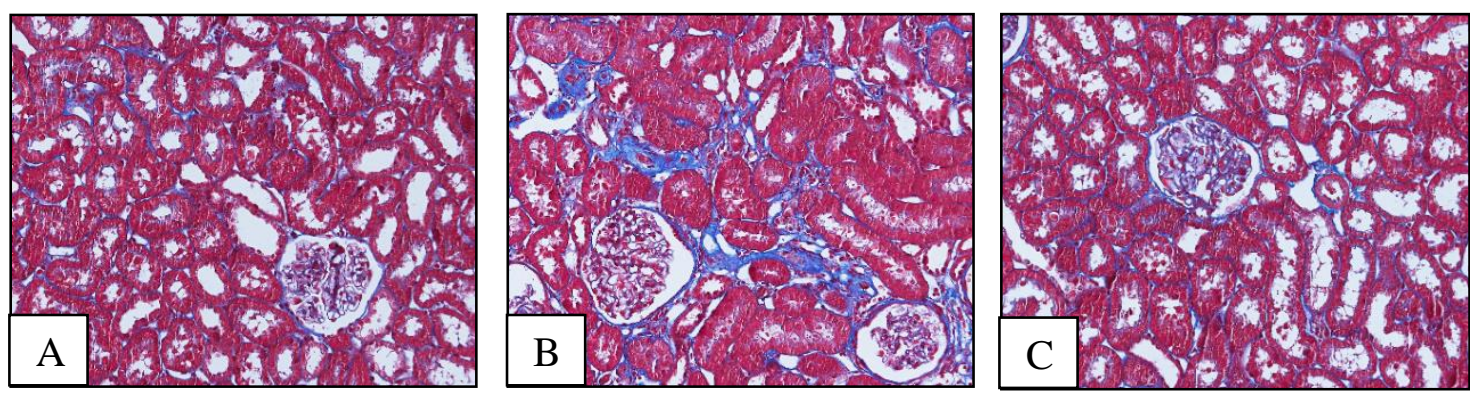

Figura 18. Cortes histológicos corados com tricromio de Masson mostrando fibrose intersticial (azul) dos grupos experimentais 6 meses pós-transplante

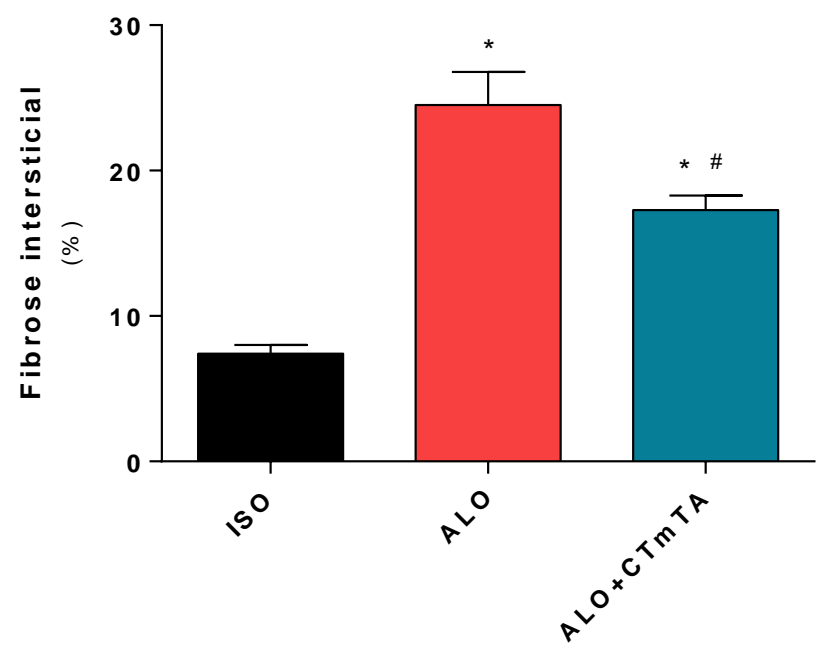

Figura 19. Gráfico expondo a contagem de fibrose intersticialdos grupos experimentais 6 meses pós-transplante. ${ }^{*} p<0,05$ vs. ISO e \# $p<0,05$ vs. ALO 


\subsection{Imunohistoquímica}

\subsubsection{Linfócitos}

Os animais do grupo ALO (figura 23B) apresentaram um aumento significativo do número de linfócitos T quando comparado ao grupo ISO (figura 23A) (26 \pm 6 céls $/ \mathrm{mm}^{2}$ ALO vs. $8 \pm 4$ céls $/ \mathrm{mm}^{2} I S O ; p<0,05$ ). O tratamento com CTmTA, (figura 23 C) preveniu o aumento do infiltrado de linfócitos de forma significativa (10 \pm 5 céls/mm²vs. ALO; $\mathrm{p}<0,05)$ (Figuras 24)

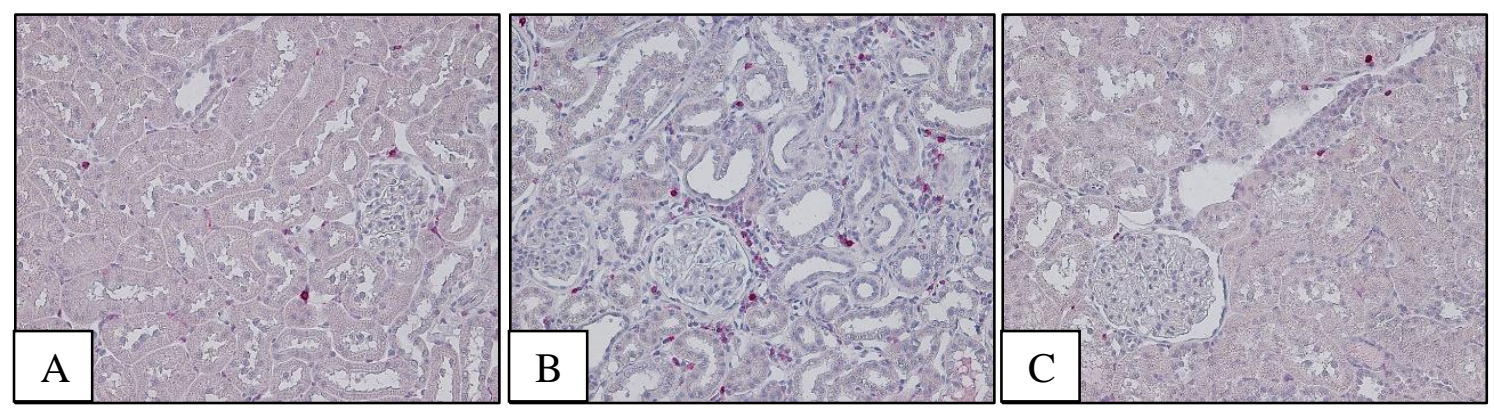

Figura 20: Determinação de linfócitos $\left(\mathrm{CD}^{+}\right)$através de imuno-histoquímica. (A) ISO; (B) ALO; (C) ALO+CTmTA

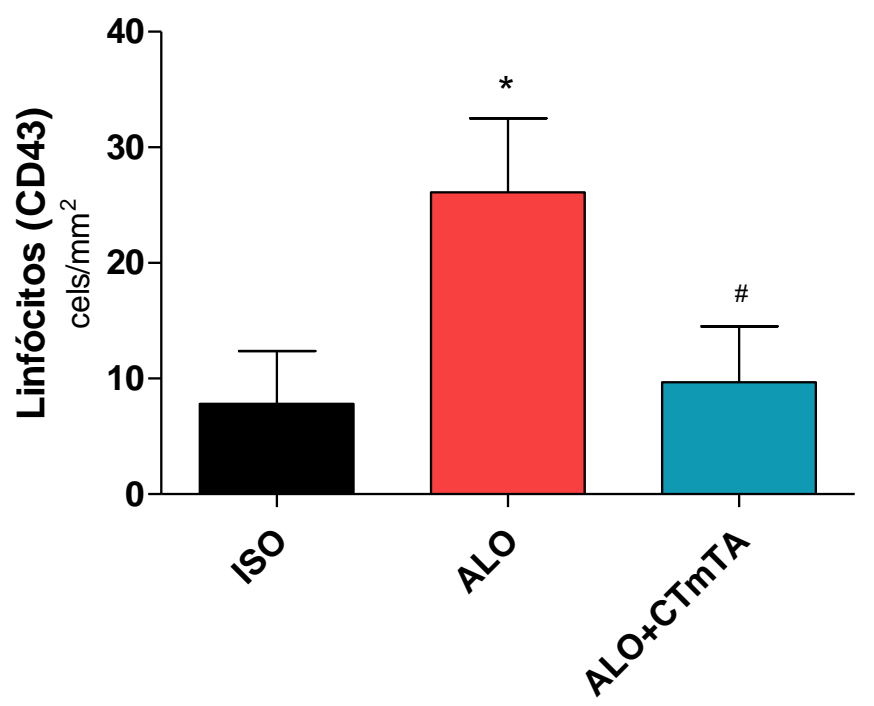

Figura 21: $\mathrm{O}$ gráfico apresenta à média referente ao número de linfócitos $\left(C D 3^{+}\right)$em cada grupo no 6 meses pós-transplante. ${ }^{*} p<0,05$ vs. ISO e \# $p<0,05$ vs. ALO 


\subsubsection{Macrófagos}

O grupo ALO apresentou um aumento significativo do infiltrado de macrófagos quando comparado ao grupo ISO ( $384 \pm 35$ cels $/ \mathrm{mm}^{2}$ ALO vs. $45 \pm 3$ céls $/ \mathrm{mm}^{2} I S O$; $\mathrm{p}<0,05)$. O tratamento com CTmTA, preveniu o aumento infiltrado de macrófagos do grupo ALO+CTmTA $\left(268 \pm 42\right.$ cels $/ \mathrm{mm}^{2} v s$. ALO; $\left.p<0,05\right)$ (Figura 19; Figura 20).
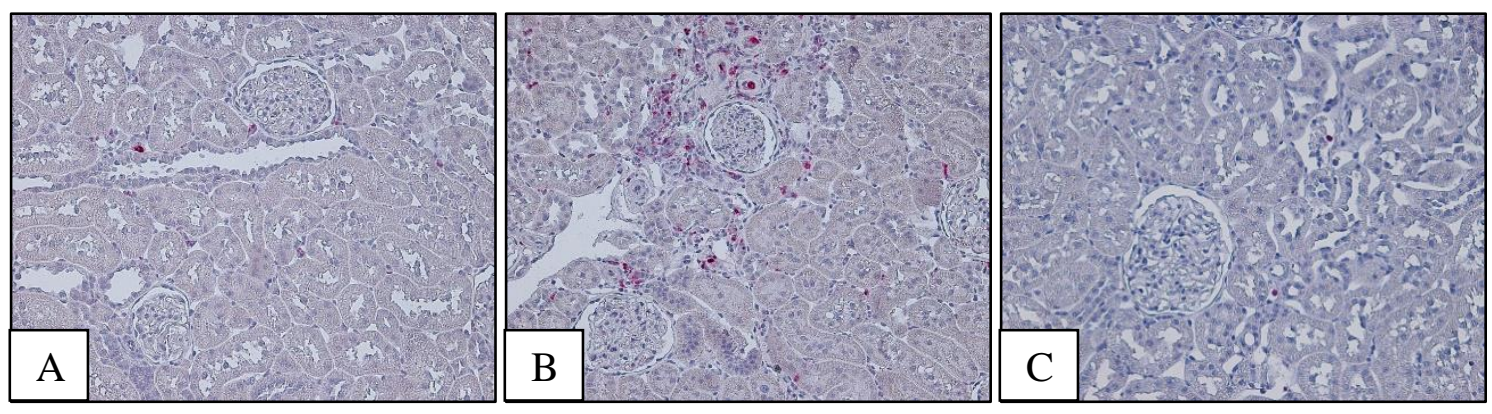

Figura 22: Determinação de Macrófagos (ED1+) através de imuno-histoquímica. (A) ISO; (B) ALO; (C) ALO+CTmTA.

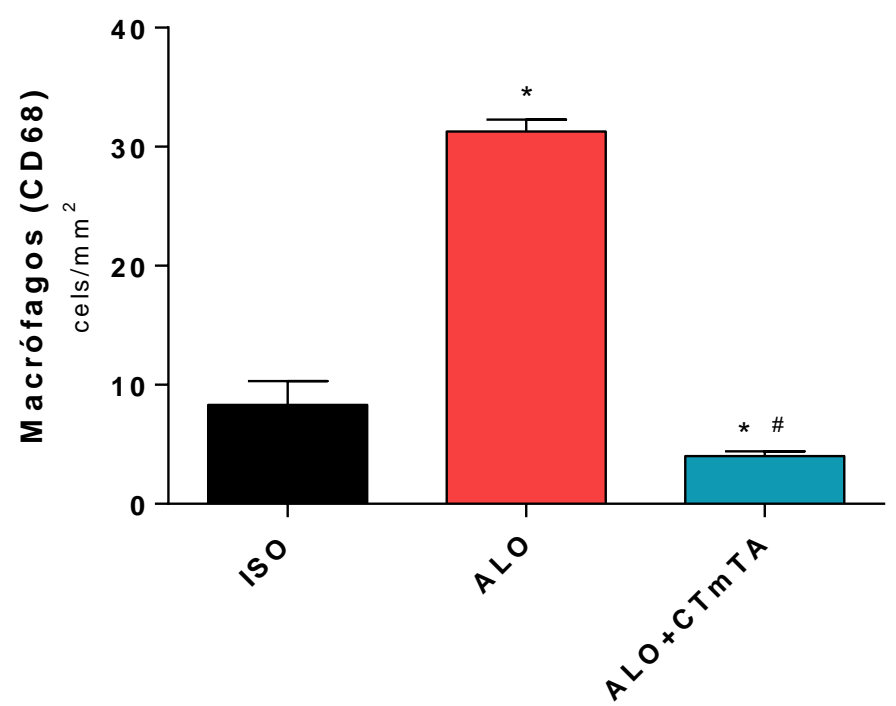

Figura 23: O gráfico apresenta a média e erro padrão referente ao número de Macrófagos $\left(C D 68^{+}\right)$em cada grupo no 6 meses pós-transplante. ${ }^{*} p<0,05$ vs. ISO e \# $p<0,05$ vs. ALO 
Tabela 14. Análise histológica do enxerto renal 6 meses pós-transplante

\begin{tabular}{lccc}
\hline & \multicolumn{3}{c}{ GRUPOS } \\
\cline { 2 - 4 } PARAMETROS & ISO & ALO & ALO+CTmTA \\
\hline Fibrose (\%) & $7,4 \pm 0,6$ & $24,5 \pm 2,3^{\star}$ & $17,3 \pm 1,0^{\star} \#$ \\
Macrófagos $\left(\mathrm{cels} / \mathrm{mm}^{2}\right)$ & $8 \pm 2$ & $31 \pm 1^{*}$ & $4 \pm 0,4^{\star} \#$ \\
Linfócitos $\left(\mathrm{cels} / \mathrm{mm}^{2}\right)$ & $8 \pm 4$ & $26 \pm 6 *$ & $10 \pm 5 \#$ \\
\hline
\end{tabular}




\subsection{PCR em Tempo Real}

\subsubsection{Interleucinas pró-inflamatórias}

O grupo ALO apresentou uma expressão significativamente maior de TNF-a, IL1ß, IL-6 e INF- $\gamma$ em relação ao grupo ISO. O tratamento com CTmTA reduziu de forma significativa a expressão dessas interleucinas (Figura 21).

Tabela 15. Expressão de citocinas pró-inflamatórias no enxerto renal 6 meses pós -transplante. ${ }^{*} p<0,05$ vs. ISO e \# $p<0,05$ vs. ALO

\begin{tabular}{lccc}
\hline & \multicolumn{3}{c}{ GRUPOS } \\
\cline { 2 - 4 } CITOCINAS & ISO & ALO & ALO+CTmTA \\
\hline TNF- $\boldsymbol{\alpha}$ (relative expression/18S) & $1,0 \pm 0,2$ & $2,5 \pm 0,3^{*}$ & $1,0 \pm 0,4^{* \#}$ \\
IL- $\boldsymbol{\beta}$ (relative expression/18S) & $1,0 \pm 0,2$ & $2,4 \pm 0,4^{*}$ & $1,0 \pm 0,3$ \\
IL-6 (relative expression/18S) & $1,0 \pm 0,2$ & $5,4 \pm 0,3^{*}$ & $3,0 \pm 0,4^{* \#}$ \\
IFN- $\boldsymbol{\gamma}$ (relative expression/18S) & $1,0 \pm 0,1$ & $2,1 \pm 0,2^{*}$ & $0,4 \pm 0,3$ \\
\hline
\end{tabular}
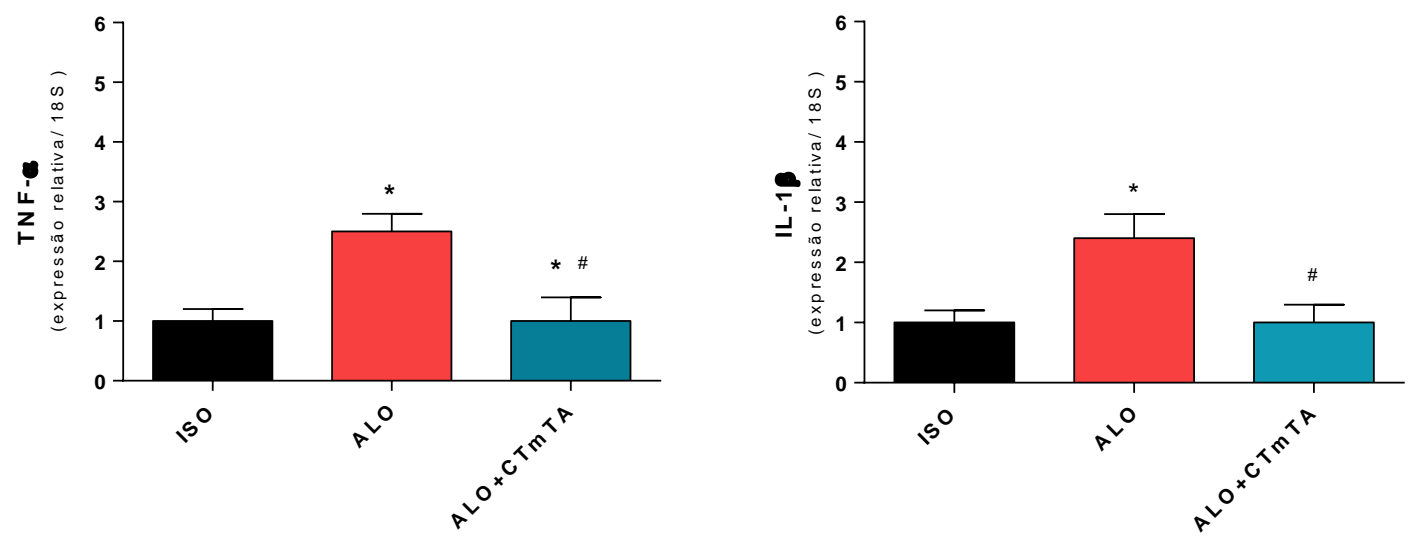

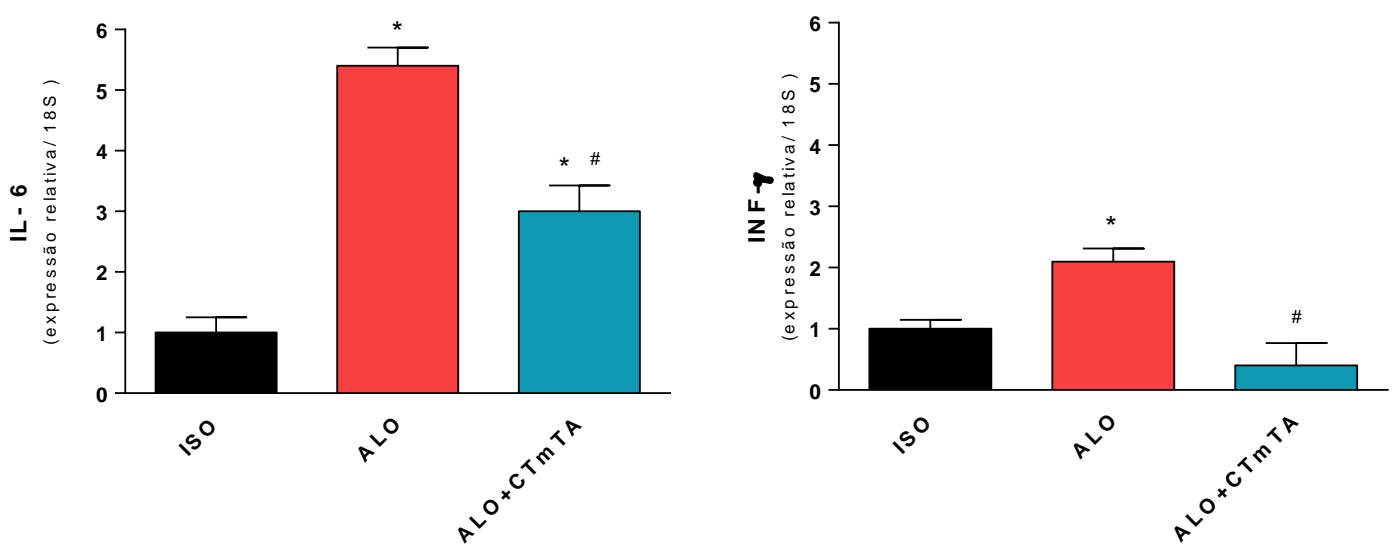

Figura 24: Expressão de TNF- $\alpha$, IL-1 $\beta$, IL-6 e INF- $\gamma$ no enxerto renal 6 meses pós-transplante. ${ }^{*} p<0,05$ vs. ISO e \# $p<0,05$ vs. ALO 


\subsubsection{Interleucinas Th2}

A análise da expressão genica das interleucinas IL-4 e IL-10 não mostrou diferença estatística entre os grupos ISO e ALO. Entretanto, os animais tratados com CTmTA apresentaram um aumento significativo desta interleucina quando comparado ao grupo ISO e ao grupo ALO. (Figura 25).

Tabela 16: Expressão de citocinas anti-inflamatórias no enxerto renal 6 meses pós -transplante. ${ }^{*} p<0,05$ vs. ISO e \# $p<0,05$ vs. ALO

\begin{tabular}{lccc}
\hline & \multicolumn{3}{c}{ GRUPOS } \\
\cline { 2 - 4 } CITOCINAS & ISO & ALO & ALO+CTmTA \\
\hline IL-4 (relative expression/18S) & $1,0 \pm 0,2$ & $1,5 \pm 0,6$ & $8,0 \pm 0,5^{* \#}$ \\
IL-10 (relative expression/18S) & $1,0 \pm 1,7$ & $0,8 \pm 1,69$ & $28,8 \pm 1,1^{* \#}$ \\
\hline
\end{tabular}
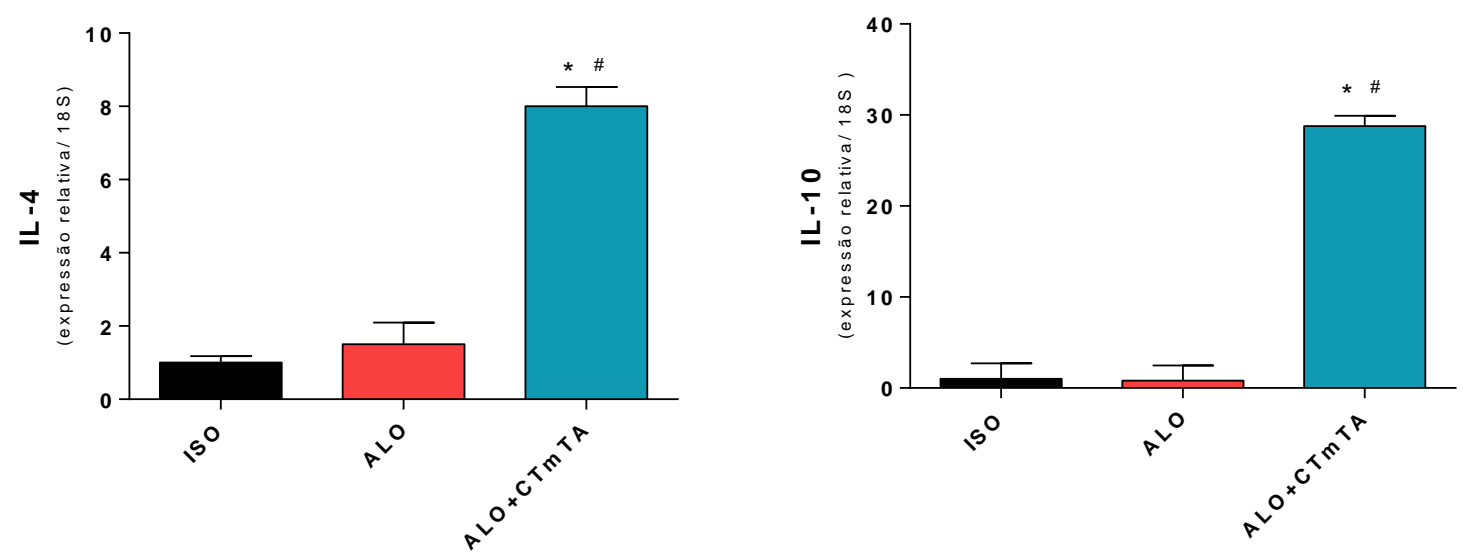

Figura 25: Expressão de IL-4 e IL10 no enxerto renal 6 meses pós-transplante. ${ }^{*} p<0,05$ vs. ISO e \# $p<0,05$ vs. ALO 


\section{Discussão}

O presente estudo teve como objetivo central analisar o potencial papel imunoregulador das CTmTA no modelo de transplante renal em ratos. Mais especificamente, analisar se a terapia celular é capaz de induzir renoproteção em um modelo de rejeição crônica ao aloenxerto renal, considerando a possibilidade de se tornar uma futura alternativa para o tratamento clínico.

Inicialmente, foram realizados experimentos para padronização do modelo de transplante renal experimental. De fato, houve diversos desafios tanto na escolha do melhor modelo a ser aplicado quanto na obtenção de habilidades microcirúrgicas específicas para a realização da técnica. Primeiramente foi escolhida a técnica de anastomome termino-lateral, que consistena sutura da artéria e da veia renal diretamente na lateral da aorta e da veia cava inferior respectivamente. Apesar de muito utilizada, esta técnica apresenta diversas complicações que devem ser questionadas. A indução de estenose venosa na região da anastomose foi o principal obstáculo encontrado nesta modalidade de transplante experimental, que pode ter ocorrido devido ao posicionamento da veia renal em ralação a veia cava bem como pelo método de anastomose utilizado. Outro ponto a ser considerado é a necessidade de clampeamento da aorta na região suprarrenal para a realização das anastomoses vasculares, o que bloqueia o fluxo sanguíneo nos membros inferiores dos animais por um período superior a 30 minutos causando paraplegia irreversível em muitos animais. Para o desenvolvimento deste estudo, esta metodologia apresentou 
falhas importantes que comprometeram a viabilidade da técnica e a homogeneidade dos grupos.

Diante da grave intercorrência caracterizada pelo desenvolvimento de paraplegia e do surgimento de muitos episódios de estenose venosa, optamos por modificar a técnica, passando a utilizar a anastomose do tipo termino-terminal. Este procedimento consiste na anastomose das artéria e veia renais do doador, diretamente na artéria e veia renais do receptor, respectivamente. Apesar de consideravelmente mais complexa, devido ao calibre dos vasos e da sua difícil manipulação, esta técnica permite que o fluxo sanguíneo para os membros inferiores se mantenha durante o ato cirúrgico, pois apenas o fluxo sanguíneo do rim é interrompido. Ao passarmos a utilizar este tipo de anastomose, não houve mais comprometimento dos membros inferiores dos animais. Além do que, não foram observadas estenoses ou outras complicações associadas a técnica.

Com o estabelecimento do melhor método de anastomose vascular, foi possível então, iniciar o treinamento das anastomoses do ureter, que se apresentaram particularmente desafiadoras. O ureter é um conduto de difícil manipulação devido ao seu calibre e sua instabilidade, de modo que foram necessárias muitas horas de treino para que o as anastomoses do ureter ficassem satisfatórias. Isso pois, no ato cirúrgico era frequente a transposição dos pontos pelas paredes do ureter, gerando uma obstrução ureteral importante, que comprometia o fluxo urinário e consequentemente a viabilidade do enxerto. Conforme as habilidades cirúrgicas foram sendo alcançadas, surgiu a necessidade da verificação do tempo cirúrgico, para que não houvesse uma demasiada extrapolação do 
período de esquemia a frio ao qual o órgão era submetido. Segundo a literatura, o tempo de isquemia máximo desejável está entre 30 a 40 min ${ }^{163,164}$. Neste trabalho, o tempo ideal de isquemia fria (máximo $40 \mathrm{~min}$ ) foi alcançado com sucesso após 12 meses de treinos.

Após a padronização do modelo experimental, os animais submetidos ao alotransplante foram acompanhados durante 6 meses e desenvolveram características de nefropatia crônica do enxerto, semelhantes às encontradas em humanos como hipertensão arterial, proteinúria, piora da função renal além de prevenir a fibrose intersticial e a presença de infiltrado inflamatório difuso. Conforme observado em estudos anteriores ${ }^{165,166}$, o alotransplante renal induziu um aumento de $28 \%$ na ureia sérica, de três vezes na creatinina sérica e um aumento siginificativo da pressão sistólica. Além disso, também observamos proteinúria, fração de excreção de $\mathrm{Na}+$ e $\mathrm{K}+$ elevadas e diminuição do claerance de creatinina. O modelo de rejeição induzido pelo alotransplante renal foi, portanto, padronizado com sucesso.

A inoculação das CTmTA foi feita na região subcapsular renal, pois independente dos mecanismos de renoproteção induzido pelas CTm, é atrativa a hipótese de que um maior número de células, o mais próximo possível do local lesionado, propicie uma interação mais duradoura com o órgão alvo. O "delivery" dessas células nas proximidades da lesão poderia ser importante para que o efeito protetor seja prolongado. Em um estudo comparativo de vias de infusão em modelo de lesão renal aguda induzida por cisplatina, demonstrou-se um ganho funcional com a inoculação de CTm na região subcapsular, em relação à 
administração pela artéria renal e a posterior localização das células na região córtico-medular renal, resultado não observado com a infusão sistêmica ${ }^{167}$. Esta capacidade de migração das CTm através do tecido renal também foi demonstrada anteriormente em um trabalho realizado por nosso grupo, em um estudo experimental no modelo de DRC induzida por ablação 5/6 e administração de CTm na região subcapsular ${ }^{168}$. A capacidade de migração intrarenal das CTm pode estar relacionada com a presença do receptor de superfície celular CD44, uma proteoglicana envolvida na regulação da proliferação, diferenciação e migração celular, e é influenciada pela interação positiva com o ácido hialurônico. Foi observado em modelo de lesão renal aguda, que CTm provenientes de camundongos knockout para CD44 perderam a capacidade de migrar para o local da lesão ${ }^{169}$.

Uma vez que o grupo ALO apresentou parâmetros característicos de rejeição crônica ao aloenxerto, passamos ao próximo passo do trabalho, no qual as CTmTA foram usadas como possível terapia preventiva de rejeição. $O$ fato de que os animais submetidos ao alotransplante e que receberam CTmTA mantiveram a pressão arterial em níveis semelhantes ao do grupo ISO, confirma resultados anteriores do nosso grupo, em modelo de DRC em ratos, ${ }^{168}$ tratados com Ctm de líquido amniótico e de Oliveira e colaboradores, ${ }^{170}$ em modelo experimental de ratos espontaneamente hipertensos tratados com CTmMO. Em ambos os casos verificou-se a manutenção dos níveis pressóricos normais.

Apesar de ainda não compreendermos completamente os mecanismos pelo qual as CTmTA controlam a elevação da pressão arterial, aparentemente há um efeito 
hemodinâmico benéfico propiciado pela terapia celular, que pode estar relacionado à liberação de mediadores locais. Um estudo recente mostrou que a infusão intra-arterial de CTmTA autólogas, derivadas de pacientes com doença renovascular aterosclerótica, aumentou o fluxo sanguíneo e a perfusão cortical após 3 meses. O aumento da perfusão renal foi associado a uma redução mensurável da fração de hipóxia e estabilização da taxa de filtração glomerular 171. Estudos com CTm em modelos de nefropatia crônica correlacionaram os menores níveis pressóricos observados com a melhora obtida nos índices de glomeruloesclerose e de fibrose intersticial ${ }^{168,172}$.

O papel do sistema renina-angiotensina, neste contexto, também deve ser enfatizado. Sedrakyan e colaboradores demonstraram que a expressão do receptor de angiotensina II em podócitos estimulados com angiotensina II, diminui quando as CTm são adicionadas à cultura, atingindo níveis semelhantes ao observado quando os podócitos são tratados com losartan. Portanto, as Ctm antagonizam a angiotensina II e influenciam a regulação do sistema reninaangitensina $^{173}$.

Outro mecanismo que pode estar relacionado ao controle da pressão arterial dos animais tratados com CTm é a ação paracrina dessas células diretamente no reparo tecidual vascular. Santana e colaboradores em modelo experimental de transplante de aorta, demonstraram que CTm de líquido amniótico, impediram de forma significativa a formação da camada noeíntima na parede vascular, impedindo a estenose vascular ${ }^{174}$. No mesmo ano, Eirin e colaboradores demonstraram, em modelo de angioplastia renal transluminal percutânea, que 
na presença de CTmTA houve melhor remodelação microvascular, redução de estresse oxidativo e redução de inflamação no rim estenótico ${ }^{175}$.

Com o avançar do tempo experimental, as dosagens de ureia e creatinina dos animais do grupo ALO revelaram azotemia, demonstrando que o rim transplantado apresentava disfunção do enxerto, com redução da taxa de filtração glomerular, o que não aconteceu com os animais tratados com CTmTA. Estes resultados são semelhantes aos encontrados por modelo de nefrectomia ${ }^{176}$, no qual o tratamento com CTmMO foi eficaz em prevenir o aumento de ureia sérica e manter os níveis do clearance de creatinina, e por Franquesa e colaboradores (2012) ${ }^{166}$ no modelo de transplante renal em ratos, onde o tratamento com as mesmas células diminuiu de forma expressiva a creatinia sérica.

Aparentemente, o principal mecanismo pelo qual as CTm protegem a função renal é pela liberação de fatores de crescimento, fatores proangiogênicos e citocinas anti-inflamatórias, cujos alvos são as células e estruturas renais. As CTmTA cultivadas in vitro liberam grandes quantidades do fator proangiogênico VEGF, que facilita a recuperação glomerular e tubular pois age na hipertrofia e na proliferação das células nestes compartimentos em resposta à redução de nefróns 175, 177, e do fator de crescimento dependente de insulina (IGF-1), importante para a nefrogênese normal, pois induz a síntese de GH que por sua vez está relacionado diretamente ao desenvolvimento renal. Em lesão renal induzida por cisplatina em camundongos, a administração de CTm silenciadas para IGF-1 limitou o efeito protetor e de auxílio na recuperação da estrutura 
tubular ${ }^{178}$. Entre outro, a produção de citocinas anti-inflamatórias pelas CTmMO, no modelo de transplante renal em ratos foram relatadas por contribuir para a regeneração renal ${ }^{166}$. Essas observações sugerem que o efeito benéfico dessas células pode ser atribuível às suas propriedades imunomoduladoras paracrinas.

A prevenção da proteinúria no grupo ALO+CTmTA foi um resultado particularmente importante, pois a proteinúria é um dos principais fatores de progressão das doenças renais. Trabalhando com transplante experimental em ratos, Franquesa e colaboradores demonstraram que o tratamento com CTmMO preveniu de forma semelhante o aumento da proteinúria, bem como OliveiraSales em um modelo de hipertensão renal ${ }^{166,179}$.

Considerando que a integridade dos podócitos está intimamente associada aos níves de proteinúria, podemos supor que as CTmTA, estejam contribuindo para a manutenção da estrutura da barreira de filtração.

De fato, Wang e colaboradores, reportaram restauro dos níveis de expressão de nefrina e podocina, proteínas da fenda diafragmática, quando ratos diabéticos receberam CTm ${ }^{180}$. Deste modo, nossos dados sugerem que os efeitos antiproteinúricos das CTmTA podem estar associados à restauração dos padrões de expressão das proteínas associadas aos podócitos e à manutenção na barreira de filtração glomerular.

É importante notar que, as CTm também podem contribuir para o repovoamento do compartimento endocapilar lesionado, atuando na outra extremidade da membrana de filtração ${ }^{181}$. 
No presente estudo verificamos pela Franção de excreção de $\mathrm{Na}^{+}\left(\mathrm{FeNa}^{+}\right)$e $\mathrm{K}^{+}$ $\left(\mathrm{FeK}^{+}\right)$, a melhora da função tubular dos animais submetidos ao alotransplante renal e tratados com CTmTA. Segundo Cóndor e colaboradores (2016), em um modelo de lesão renal por sepse, o tratamento com células tronco extraídas da geléia de wharton, resultou na melhora da fração de excreção tanto do $\mathrm{Na}+$ quanto do $\mathrm{K}+{ }^{182}$. Os mecanismos pelos quais as $\mathrm{CTm}$ melhoram a $\mathrm{FeNa}^{+}$e a $\mathrm{FeK}^{+}$são desconhecidos, contudo uma diminuição da inflamação local nos compartimentos tubulares e tubulointersticiais pôdem ser observada por imunohistoquimica nos enxertos que receberam tratamento com CTmTA.

Considerando que a melhora dos parâmetros funcionais dos animais tratado com CTmTA poderiam ser reflexo de uma ação anti-inflamatória, caracterizamos o infiltrado inflamatório no compartimento túbulo-intersticial, e analisamos a secreção local de algumas citocinas e fatores pró e anti-inflamatórios. No presente estudo, os macrófagos foram as principais células inflamatórias intersticiais encontradas 6 meses pós-transplante. O tratamento com CTmTA promoveu uma marcante redução no número de macrófagos no compartimento tubulointersticial. Resultados semelhantes foram encontrados quanto ao número de linfócitos $T$ detectados no enxerto renal 6 meses pós-transplante. $O$ tratamento com CTmTA também resultou na diminuição destas células no enxerto renal. Achados do nosso grupo mostraram que CTm de líquido amniótico foram capazes de diminuir significativamente a marcação tanto para macrófagos quanto para linfócitos no modelo de nefrectomia 5/6 ${ }^{189}$. Dados semelhantes foram encontrados por Franquesa e colaboradores (2012) em um modelo de 
transplante renal tratado com CTm de medula óssea demonstrou um menor número de macrófagos que infiltraram o parênquima renal 6 meses póstransplante ${ }^{166}$

Os efeitos imunomoduladores das CTm em linfócitos T, linfócitos B, células NK, células dendríticas ${ }^{184} 185$ e macrófagos ${ }^{186}$ têm sido amplamente investigados e a discussão sobre os efeitos das CTm sobre as células do sistema imune recai obrigatoriamente sobre a regulação da avaliação do estado de polarização de linfócitos e macrófagos.

Apesar de neste trabalho não ter sido investigada a polarização das subpopulações de macrófagos e linfócitos, nossos resultados quanto a expressão gênica dos animais do grupo tratado com CTmTA mostram diminuição das citocitas pró-inflamatórias TNF- $\alpha$, IL $1 \beta$, IL-6 e INF- $\gamma$, além de um aumento marcante da expressão das citocinas anti-inflamatórias IL-4 e IL-10, condizentes com uma polarização da resposta imune. O estado de ativação que regula a função dos macrófagos é dependente dos estímulos inflamatórios recebidos no microambiente do tecido. À medida que o processo de reparo muda da fase inflamatória inicial para a remodelação, os macrófagos exibem subsequentes estados de polarização variáveis e exercem uma diversidade de atividades funcionais ${ }^{187}$. Embora uma variedade de métodos de classificação tenham sido propostos, tipicamente acredita-se que os macrófagos estejam em um dos dois estados de polarização opostos, o subconjunto M1, classicamente pró-inflamatório ou o M2 conhecido como regulatório ${ }^{188}$. Macrófagos M1 atuando pela via clássica, estão associados à citocinas pró-inflamatórias tais como TNF- 
$\alpha, \quad I L-1 \beta$ e IFN- $\gamma$, diretamente associadas ao recrutamento de células inflamatórias adicionais para o local da lesão tecidual. Alternativamente, macrófagos M2 ativados expressam IL-10, que tem demonstrado reduzir a inflamação e, em algumas doenças auto-imunes, é um marcador presente na resolução destas doenças ${ }^{189}$.

Varios trabalhos, demonstraram que as CTm interagem com macrófagos e têm potencial para promover a polarização M2 190, 191, 192, 193 . Macrófagos humanos co-cultivados com CTm apresentaram fenótipo de células ativadas, com aumento da expressão do receptor de manose (MR) e de IL-10 e diminuição da expressão de TNF-a e IL-12, além de atividade fagocítica aprimorada ${ }^{190,193}$. Em outro estudo foi demonstrado que o meio condicionado de CTm foi capaz de estimular a mudança no perfil secreção de macrófagos sugerindo uma polarização de macrófagos $M 1$ para $M 2$, caracterizado pela produção significativamente reduzida de citocinas pró-inflamatórias, um "shift" para a produção de IL-10 e da função fagocítica ${ }^{191}$.

Ainda sobre os efeitos imunomodulatórios das CTmTA sobre os leucócitos, alguns estudos demonstraram que as CTm afetam várias propriedades dos linfócitos T e definitivamente suprimem a proliferação de linfócitos T CD4+ e CD8+. A redução da proliferação dos linfócitos $T$ foi evidente mesmo quando as células foram cocultivadas com CTm separadas por transwell, sugerindo que as CTm exercem seu papel de maneira paracrina ${ }^{194}$. 
As CTm também modulam as respostas dos linfócitos $\mathrm{T}$ por diminuirem a expressão dos marcadores de superfície de iniciação de ativação de linfóctitos T CD25, CD38 e CD69 195, 196. Em contrapartida as CTm são capazes de aumentar a proporção de células T reguladoras CD4+CD25+, aumentar a secreção de IL4, induzir a produção de IL-10, retardar a maturação de células apresentadoras de antígeno (APC), e diminuir a expressão de MHC classe II nas APCs ${ }^{197,}$ ${ }^{198}$.Sendo assim, mediante aos achados positivos tanto de expressão gênica, quanto dos parâmetros funcionais preservados dos animais, podemos predizer que as CTmTA tiveram um papel importante na regulação da inflamação do enxerto renal, conduzindo a resposta imune para um perfil protetor. $\mathrm{O}$ aumento da expressão de citocinas anti-inflamatórias IL-4 e IL-10 após transplante de CTm, sugere a transição dos linfócitos T para um perfil Th2 classicamente regulador.

A redução marcante do processo inflamatório nos animais que receberam $\mathrm{CTm}$ certamente contrubuiu para o menor desenvolvimento da fibrose intersticial renal neste grupo tratado com CTmTA, em comparação ao grupo ALO. A fibrose renal é uma complicação importante uma vez que o aumento de matriz extracelular e a proliferação de miofibroblastos mediando os mecanismos de fibrogênese no tecido leva à perda funcional do órgão. Trabalhos em modelos experimentais já demonstraram o potencial das CTmTA de prevenir a fibrogênese em fígado ${ }^{199} \mathrm{e}$ rim ${ }^{200}$ e um dos mecanismos propostos para explicar este fenômeno é a inibição da expressão de INF-y, interleucina responsável por induzir a superexpressão de IL-6 e TNF- $\alpha^{201}$. 
A IL-6 aumenta a síntese de colágeno, de glicosaminoglicano e a produção de MCP-1 e IL-6 por fibroblastos 202, 203. Além disso, a IL-6 regula a expressão de VEGF, um importante mediador da angiogênese e fibrose ${ }^{204}$. O TNF- $\alpha$ apresenta um efeito pró-fibrótico indireto, através da indução de TGF- $\beta$ por fibroblastos ${ }^{205}$, que por sua vez desempenha um papel central no equilíbrio tecidual estimulando a expressão de componentes da matriz, tais como fibronectina, colágeno e proteoglicanos da matriz ${ }^{206}$. Portanto, é provável que a inibição de IFN-ү pelas CTm, verificado no presente trabalho, tenha atenuado os desfechos inflamatórios e fibróticos da lesão pós-transplante.

Para explorar os mecanismos moleculares envolvidos na rejeição ao aloenxerto, diversas citocinas pró-inflamatórias foram analisadas. Efeitos benéficos das CTmTA sobre o aloenxerto foram relacionados à expressão das citocinas TNF$\alpha$, IL1- $\beta$, IL-6 e IFN- $\gamma$. Song e colaboradores demonstraram que as expressões de IL-1 $\beta$, IL-6 e TNF- $\alpha$ foram significativamente suprimidas após a administração de CTmTA. Furuichi e colaboradores (2012), também mostraram que as CTmTA foram capazes de melhorar os níveis séricos de citocinas (IL-1 $\beta$ e TNF- $\alpha$ ), no modelo de isquemia renal aguda levando auma atividade antiinflamatória e melhora da necrose tubular ${ }^{207}$.

È importante notar que 6 meses após o transplante, além de uma diminuição significativa da expressão das interleucinas pró-inflamatórias os animais tratados com CTmTA apresentaram um aumento promissor da expressão das interleucinas IL-4 e $\quad$ IL-10. A IL-10 apresenta potente atividade imunossupressora, inibindo a ativação de células $T$ e asecreção de citocinas 
Th1, além de diminur os receptores de co-estimulação em APCs ${ }^{208}$. Já a IL-4 age como uma citocina anti-inflamatória, bloqueando a síntese de IL-1, TNF-a, IL-6 e proteína inflamatória por macrófagos.

Por fim, perante ao exposto acima, os dados do presente estudo permitem concluir que o tratamento com CTmTA no modelo de transplante renal em ratos atenua a progressão da rejeição crônica ao enxerto renal caracterizado pela melhora da hipertensão arterial, proteinuria e da função renal, além de proteção contra o desenvolvimento de fibrose do enxerto. Este desfecho é provavelmente decorrente da modulação da resposta inflamatória (diminuição do infiltrado próinflamatório e das citocinas Th1 pró-inflamatórias) e do aumento de citocinas Th2. Estes resultados fortalecem a importância de novos estudos tanto nas áreas de pesquisa básica, como pré-clínica para melhor compreensão não apenas dos mecanismos como de estratégias de tratamento com terapia celular para que possa ser traduzida para pesquisa clínica em pacientes. 


\section{Conclusão}

O modelo experimental de transplante renal em ratos com indução de rejeição crônica foi padronizado com sucesso.

A terapia com CTmTA em animais alotransplantados foi capaz de preservar a função renal, evitar a hipertensão arterial e a proteinúria além de manter a função tubular.

Além disso, o tratamento com CTmTA foi capaz proteger o enxerto renal do infiltrado inflamatório e da fibrogênese.

Concluimos que a terapia celular com CTmTA em modelo de rejeição crônica apresentou efeitos benéficos para a evolução do enxerto renal. 


\section{Referências}

1. Nankivell BJ, Alexander SI. Rejection of the Kidney Allograft. N Engl J Med 2010; 363:1451-1462

2. Hariharan S, Johnson CP, Bresnahan BA, Taranto SE, Mcintosh MJ, Stablein D.: Improved graft survival Lafter renal transplantation in the United States, 1988 to 1996. N Engl J Med 2000; (342): 605-612.

3. Marcén R. Immunosuppressive drugs in kidney transplantation: impact on patient survival, and incidence of cardiovascular disease, malignancy and infection. Drugs. 2009 Nov 12;69(16):2227-43.

4. Halloran PF, Broski AP, Batiuk TD, Madrenas J. The molecular immunology of acute rejection: an overview. Transpl Immunol. 1993;1(1):3-27.

5. Briscoe DM, Alexander SI, Lichtman AH. Interactions between $\mathrm{T}$ lymphocytes and endothelial cells in allograft rejection. Curr Opin Immunol 1998;10:525-531.

6. Halloran P. F. T Cell-mediated Rejection of Kidney Transplants: A Personal Viewpoint. American journal of Transplantation. Volume 10, Issue 5 May 2010. Pages 1126-1134

7. Noronha IL, Manfro, RC. Imunossupressão e resposta imune In: Manfro RC, Noronha IL, Pacheco-Silva A, editores. Manual de transplante renal, $2^{a}$ edição. São Paulo: Manole, 2014 p. 151-162

8. Kadkhodaee M, Najafi A, Seifi B. Classical and remote post conditioning effects on ischemia/reperfusion-induced acute oxidant kidney injury. Int $\mathrm{J}$ Surg. 2014; 12(11):1162-6.

9. O'Neill S, Harrison EM, Ross JA, Wigmore SJ, Hughes J.Heat-shock proteins and acute ischaemic kidney injury. Nephron Exp Nephrol. 2014;126(4):167-74

10.Shi Z, Lian A, Zhang F. Nuclear factor-kB activation inhibitor attenuates ischemia reperfusion injury and inhibits Hmgb1 expression. Inflamm Res. 2014; 63(11):919-25.

11. Suresh $\mathrm{R}$, Mosser DM. Pattern recognition receptors in innateimmunity, host defense, and immunopathology. AdvPhysiol Educ. 2013; 37(4): 28491. 
12. Fujiwara N, Kobayashi K. Macrophages in inflammation. Curr Drug Targets Inflamm Allergy 2005; 4:281-8.

13. Cruvine Wilson de Melo, Danilo Mesquita Júnior, Júlio Antônio Pereira Araújo, Tânia Tieko Takao Catelan , Alexandre Wagner Silva de Souza , Neusa Pereira da Silva, Luís Eduardo Coelho Andrade .Sistema Imunitário - Parte I Fundamentos da imunidade inata com ênfase nos mecanismos moleculares e celulares da resposta inflamatória Rev Bras Reumatol 2010;50(4):434-61

14. Cardoni RL1, Prigoshin N, Tambutti ML, Ferraris JR. Regulatory cytokines in the response to the allogeneic renal transplant. Medicina (B Aires). 2005;65(1):54-62.

15. Lebre MC, Burwell T, Vieira PL, Lora J, Coyle AJ, Kapsenberg ML, Clausen BE, De Jong EC. Differential expression of inflammatory chemokines by Th1- and Th2-cell promoting dendritic cells: a role for different mature dendritic cell populations in attracting appropriate effector cells to peripheral sites of inflammation. Immunol Cell Biol. 2005 Oct;83(5):525-35.

16. Kimura A, Naka T, Kishimoto T. IL-6-dependent and -independent pathways in the development of interleukin 17-producing $\mathrm{T}$ helper cells. Proc Natl Acad Sci U S A. 2007 Jul 17;104(29):12099-104.

17. Steinman L. A brief history of $\mathrm{T}(\mathrm{H}) 17$, the first major revision in the $\mathrm{T}(\mathrm{H}) 1 / \mathrm{T}(\mathrm{H}) 2$ hypothesis of $\mathrm{T}$ cell-mediated tissue damage. Nat Med. 2007 Feb;13(2):139-45.

18.Ivanov, II, Zhou L, Littman DR. Transcriptional regulation of Th17 cell differentiation. Semin Immunol. 2007 Dec;19(6):409-17.

19. McGeachy MJ, Cua DJ. Th17 cell differentiation: the long and winding road. Immunity. 2008 Apr;28(4):445-53.

20.Danchin E1, Vitiello V, Vienne A, Richard O, Gouret P, McDermott MF, Pontarotti P. The major histocompatibility complex origin. Immunol Rev. 2004 Apr;198:216-32.

21. Hunt DF, Henderson RA, Shabanowitz J, Sakaguchi K, Michel H, Sevilir $\mathrm{N}$, et al. Characterization of peptides bound to the class I MHC molecule HLA-A2.1 by spectrometry. Science (1992) 255:12613.10.1126/science.1546328

22. Rammensee, H.G.; Bachmann, J.; Stevanović, S. MHC ligands and peptide motifs. Austin: Landes Bioscience, 1997. 
23. Janeway, C.A.J; Travers, P.; Walport, M.; Shlomchick, M. Immunobiology: the immune system in health and disease. 5 ed. New York: Garland Publishing, 2001.

24. Abbas, A.K.; Lichtman, A.H. Imunologia Celular e Molecular.Reall, C. [Trad] 2005. 5.ed. Rio de Janeiro: Elsevier.

25. McCaffery D. A review of transplant immunology. Crit Care NursClin North Am. 2011; 23(3):393-404.

26. Hongzhen He, James R Stone, and David L Perkins.Analysis of differential immune responses induced by innate and adaptive immunity following transplantation.Immunology. 2003; 109(2): 185-196.

27. Wood KJ, Goto R. Mechanisms of rejection: current perspectives. Transplantation. 2012; 93(1):1-10.

28. Marino J, Paster J, Benichou G. Allorecognition by T Lymphocytes and Allograft Rejection. Front Immunol. 2016 Dec 14;7:582.Joudeh A, Saliba KA, Topping KA, Sis B. Pathologic basis of antibody-mediated organ transplant rejection: from pathogenesis to diagnosis. CurrOpin Organ Transplant. 2013; 18(4):478-485.

29. Joudeh A, Saliba KA, Topping KA, Sis B. Pathologic basis of antibodymediated organ transplant rejection: from pathogenesis to diagnosis. CurrOpin Organ Transplant. 2013; 18(4):478-485.

30. Cornell LD, Smith RN, Colvin RB. Kidney transplantation: mechanisms of rejection and acceptance. Annu Rev Pathol.2008; 3:189-220.

31. Rosen Hugo R. Transplantation Immunology: What the Clinician Needs to Know for Immunotherapy. Gastroenterology 2008;134:1789-1801

32. Harris N.L. Ronchese F. The role of B7 costimulation in T-cell immunity. Immunology and CellBiology (1999) 77, 304-311.

33. TsushimaF, Sheng Yao, Tahiro Shin, Andrew Flies, Sarah Flies, Haiying $\mathrm{Xu}$, Koji Tamada, Drew M. Pardoll and Lieping Chen. Interaction between $\mathrm{B} 7-\mathrm{H} 1$ and PD-1 determines initiation and reversal of T-cell anergy. Blood 2007 110:180-185

34. Chen L. Co-inhibitory molecules of the B7-CD28 family in the control of Tcell immunity. Nature Rev Immunol 2004; 4:336-347

35. Dure M. and Macian F. IL-2 signaling prevents T cell anergy by inhibiting the expression of anergy inducing genes. Mollmmunol. 2009 Feb; 46(5): 999-1006. 
36. Broere F, Apasov S.G., Sitkovsky M. V and Eden W van. T cell subsets and $T$ cell-mediated immunity. Principles of Immunopharmacology: 3rd revised and extended edition.Nijkamp, F.P.; Parnham, M.J, 2011, XXXI, 728 p.162

37. Williams TJ. The role of prostaglandins in inflammation. Ann R Coll Surg Engl. 1978 May; 60(3): 198-201.

38. Edward A. Dennis and Paul C. Norris. Eicosanoid Storm in Infection and Inflammation. Nat Rev Immunol. 2015 Aug; 15(8): 511-523.

39. Sharma JN, Al-Omran A, Parvathy SS. Role of nitric oxide in inflammatory diseases. Inflammopharmacology. 2007 Dec;15(6):252-9

40. Rong Jin, Guojun Yang, and Guohong Li. Inflammatory mechanisms in ischemic stroke: role of inflammatory cells. J Leukoc Biol. 2010 May; 87(5): 779-789.

41. Almond PS, Matas A, Gillingham K, et al. Risk factors for chronic rejection in renal allograft recipients. Transplantation 1993; 55: 752; discussion 756. 4.

42. Paul LC. Chronic allograft nephropathy: an update. Kidney Int 1999; 56: 783. 5.

43. Humar A, Hassoun A, Kandaswamy R, Payne WD, Sutherland DE, Matas AJ. Immunologic factors: the major risk for decreased long-term renal allograft survival. Transplantation 1999; 68: 1842

44. Madden RL, Mulhern, JG, Benedetto, BJ, et al: Completely reversed acute rejection is not a significant risk factor for the development of chronic rejection in renal allograft recipients. Transplant Int. 2000 13:344-350.

45. Meier-Kriesche, HU, Schold, JD, Srinivas, TR, et al: Lack of improvement in renal allograft survival despite a marked decrease in acute rejection rates over the most recent era. Am J Transplant 2004 4:378-383

46. Noronha I.L, Oliveira A.C, bensur HA, Romão Jr J.E, Araújo M.R.T, Zatz $R$, Mycophenolate mofetil in the treatment of chronic rejection in renal transplantation: 3-year follow-up. Transplantation Proceedings. Volume 34, Issue 2, March 2002, Pages 491-493

47. Racusen LC, Regele $\mathrm{H}$. The pathology of chronic allograft dysfunction. Kidney Int Suppl. 2010 Dec;(119):S27-32. 
48. Moreso F, Ibernon M, Gomà M, Carrera M, Fulladosa X, Hueso M, GilVernet S, Cruzado JM, Torras J, Grinyó JM, Serón D. Subclinical rejection associated with chronic allograft nephropathy in protocol biopsies as a risk factor for late graft loss.Am J Transplant. 2006 Apr;6(4):747-52.

49. Solez K, Colvin RB, Racusen LC, et al. Banff 07 classification of renal allograft pathology: updates and future directions. Am J Transplant 2008;8:753-760

50. Tomasoni S, Remuzzi G, Benigni A. Allograft Rejection: Acute and Chronic Studies. Gene Therapy for Renal Diseases and Transplantation. Contrib Nephrol. Basel, Karger, 2008, vol 159, pp 122-134

51.Baluja P1, Haragsim L, Laszik Z. Chronic allograft nephropathy. Adv Chronic Kidney Dis. 2006 Jan;13(1):56-61.

52. Mitchell RN. Graft vascular disease: immune response meets the vessel wall. Annu Rev Pathol. 2009;4:19-47.

53.Zheng Q, Liu S, Song Z. Mechanism of arterial remodeling in chronic allograft vasculopathy. Front Med. 2011;5(3):248-253.

54. Hillebrands JL, Klatter FA, van den Hurk BM, Popa ER, Nieuwenhuis P, Rozing J. Origin of neointimal endothelium and alpha-actin-positive smooth muscle cells in transplant arteriosclerosis. J Clin Invest. 2007;107(11):1411-1422.

55. Davis R, Pillai S, Lawrence N, Sebti S, Chellappan SP. TNF-_-mediated proliferation of vascular smooth muscle cells involves Raf-1-mediated inactivation of $\mathrm{Rb}$ and transcription of E2F1-regulated genes. Cell Cycle. 2012;11(1):109-118.

56. Wang Z, Newman WH. Smooth muscle cell migration stimulated by interleukin 6 is associated with cytoskeletal reorganization. J Surg Res. 2003;111(2):261-266.

57. Yu L, Qin L, Zhang H, He Y, Chen H, Pober JS, Tellides G, Min W. AIP1 prevents graft arteriosclerosis by inhibiting interferon-_-dependent smooth muscle cell proliferation and intimal expansion. Circ Res. 2011;109(4):418427.

58. Colvin RB. Antibody-mediated renal allograft rejection: diagnosis and pathogenesis. J Am Soc Nephrol. 2007 Apr;18(4):1046-56. Epub 2007 Mar 14.

59. Solez K. Making global transplantation pathology standards truly global. Am J Transplant. 2007 Dec;7(12):2834. Epub 2007 Oct 9. 
60. Ingulli E.Mechanism of cellular rejection in transplantation. Pediatr Nephrol. 2010 Jan;25(1):61-74.

61. Degauque N, Mariat C, Kenny J, Sanchez-Fueyo A, Alexopoulos SP, Kuchroo V, Zheng XX, Strom TB.Regulation of T-cell immunity by Tcell immunoglobulin and mucin domain proteins. Transplantation. $2007 \mathrm{Jul}$ 15;84(1 Suppl): S12-6.

62. Tomasek JJ1, Gabbiani G, Hinz B, Chaponnier C, Brown RA. Myofibroblasts and mechano-regulation of connective tissue remodelling. Nat Rev Mol Cell Biol. 2002 May;3(5):349-63.

63. LIU, Y. Epithelial to mesenchymal transition in renal fibrogenesis: pathologic significance, molecular mechanism, and therapeutic intervention. Journal of the American Society of Nephrology, v.15, p.1-12, 2004.

64. Kindt, Thomas J, Goldsby, Richard A. Osborne, Barbara AnneKuby, Janis. 1939. Kuby immunology. 6th ed. New York: W.H. Freeman, 2007.

65. Till JE, Mcculloch EA, Siminovitch L. A stochastic model of stem cell proliferation, based on the growth of spleen colony-forming cells. Proc Natl Acad Sci. 1964;51(1): 29-36.

66. Drzewiecki BA, Thomas JC, Tanaka ST. Bone marrow-derived mesenchymal stem cells: current and future applications in the urinary bladder. Stem Cells Int. 2010 Jan 3; 2010:765167.

67. Friedenstein A. J., Chailakhjan R. K., LAlykina K. S. The Development of Fibroblast Colonies in Monolayer Cultures of Guinea-pig Bone Marrow and Spleen Cells. Cell Tissue Kinet. 1970, 3, 393-403.

68. Morrison $\mathrm{Sj}$, Shan $\mathrm{Nm}$, Anderson Dj. Regulatory mechanisms in stem cell biology. Cell. 1997; 88:287-298.

69. Del Carlo RJ. Células-tronco. Revista do Conselho Federal de medicina Veterinaria Sup Técnico2005; 60-68. 
70. Vogel G. Can old cells learn new tricks? Science Washington. 2000. 287: 1418-1419.

71. Gage FH. 2000. Mammalian neural stem cells. Science Washington DC. 287: $1433-1438$.

72. Robey PG. 2000. Stem cells near the century mark. J Clin Invest Thorofare. 105(11): 1489-1491.

73. Odorico JS, Kaufmann DS, Thomson JA. 2001. Multilineage differentiation from human embryonic stem cell lines. Stem Cells Dayton. 19:193-204.

74. Chiu C. 1996. Differential expression of telomerase activity in hematopoietic progenitors from adult human marrow. Stem Cells; 14:239248.

75. Watt FM, Hogan BLM. Out of the Eden: stem cells and their niches. Science Washington DC. 2000. 287: 1427-1430.

76. Gritti A, Vescovi AL, Galli R. 2002. Adult neural stem cells plasticity and developmental potential. J. Physiol. Paris. 96 1/2: 81-89.

77. Heissig B, Ohki Y, Sato Y. 2005. A role for niches in hematopoietic cell development. Hematology. 10: 247-253

78. Leri A, Kajstura J, Anversa P. Cardiac stem cells and mechanisms of myocardial regeneration. Physiol Rev. 2005. 85: 1373-1416.

79. Hara Y, Kitazawa Y, Funeshima N, Kawasaki M, Sato Y, Tezuka K, Kimura $\mathrm{H}$, Hatakeyama K, Li XK. Anergic lymphocytes generated by blocking CD28 and ICOS pathways in vitro prolong rat cardiac graft survival. Int Immunopharmacol. 2006 Jul;6(7):1143-51.

80. Tumbar T, Guasch G, Greco V. Defining the epithelial stem cell niche in skin. Science 2004. 303: 359-363

81. Guettier C. 2005. Which stem cells for adult liver? Ann Pathol. 25: 33-44.

82. Slack JMW. Stem cells in epithelial tissues. 2000. Science Washington. 287:1431-1433.

83. Brittan M, Wright NA. Gastrointestinal stem cells. J Pathol. 2002. 197: 492- 509.

84. Modlin IM, Kidd M, Lye KD. Gastric stem cells: An update. Keio J Med. 2003. 52:134-137. 
85. Lavker RM, Tseng SC, Sun TT. Corneal epithelial stem cells at the limbus: Looking at some old problems from a new angle. Exp Eye Res. 2004, 78: 433-446.

86. Watts C, McConkey H, Anderson L. Anatomical perspectives on adult neural stem cells. J Anat. 2005. 207: 197-208.

87. Woodward WA, Chen MS, Behbod F. On mammary stem cells. J Cell Sci. 2005. 118: 3585-3594.

88. Kim CF, Jackson EL, Woolfenden AE. Identification of bron- chioalveolar stem cells in normal lung and lung cancer. Cell. 2005. 121: 823-835.

89. HIRAO A, ARAI F, SUDA T. 2004. Regulation of cell cycle in hematopoietic stem cells by the niche. Cell Cycle. 3: 1481-1483.

90. Caplan AI. Mesenchymal stem cells. J Orthop Res. 1991;9(5):641-50

91. Dominici M1, Le Blanc K, Mueller I, Slaper-Cortenbach I, Marini F, Krause D, Deans R, Keating A, Prockop Dj, Horwitz E. Minimal criteria for defining multipotent mesenchymal stromal cells. The International Society for Cellular Therapy position statement. Cytotherapy. 2006;8(4):315-7.

92. Maitra B, Szekely E, Gjini K, Laughlin MJ, Dennis J, Haynesworth SE, et al. Human mesenchymal stem cells support unrelated donor hematopoietic stem cells and suppress T-cell activation. Bone Marrow Transplant. 2004;33(6):597-604.

93. Krampera M, Glennie S, Dyson J, et al. Bone marrow mesenchymal stem cells inhibit the response of naive and memory antigen-specific $\mathrm{T}$ cells to their cognate peptide. Blood; 2003; 101:3722-3729.

94. Duffy MM, Ritter T, Ceredig R, Griffin MD. Mesenchymal stem cell effects on T-cell effector pathways. Stem Cell Res Ther, 2011; 2:34.

95. Fruhbeck G, Gomez-Ambrosi J, Muruzabal FJ, Burrell MA. The adipocyte: a model for integration of endocrine and metabolic signaling in energy metabolism regulation. Am J Physiol Endocrinol Metab. 2001;280:E82747. 28.

96. Osborne TF. Sterol regulatory element-binding proteins (SREBPS): key regulations of nutritional homeostasis and insulin action. $\mathrm{J}$ Biol Chem. 2000;275:32379-82.

97. Hausman GJ, Richardson RL. Adipose tissue angiogenesis. J Anim Sci. 2004;82:925-934 
98. Ailhaud G, Grimaldi P, Négrel R. Cellular and molecular aspects of adipose tissue development. Annu Rev Nutr. 1992;12:207-33.

99. Kern S, Eichler H, Stoeve J, Kluter H, Bieback K. Comparative analysis of mesenchymal stem cells from bone marrow, umbilical cord blood, or adipose tissue. Stem Cells. 2006;24:1294-301.

100. Prunet-Marcassus B, Cousin B, Caton D, Andre M,Penicaud L, Casteilla L. From heterogeneity to plasticity in adipose tissues: Site-specific differences. Exp Cell Res 2006; 312:727-36.

101. Oedayrajsingh-Varma MJ, van Ham SM, Knippenberg M, Helder MN, Klein-Nulend J, Schouten TE, et al. Adipose tissue-derived mesenchymal stem cell yieldand growth characteristics are affected by the tissue harvesting procedure. Cytotherapy. 2006; 8:166-77.

102. Lee RH, Kim BC, Choi I, Kim H, Choi HS, Suh KT, et al. Characterization and expression analysis of mesenchymal stem cells from human bone marrow and adipose tissue. Cell PhysiolBiochem. 2004; 14:311-24.

103. Chen CC, Chapman WC, Hanto DW. Ischemia-reperfusion injury in kidney transplantation. Front Biosci (Elite Ed). 2015 Jan 1; 7:134-54.

104. Hsiao S.T. Asgari A. Lokmic Z. Sinclair R. Dusting G.J. Lim S.Y. Dilley R.J. Comparative analysis of paracrine factor expression in human adult mesenchymal stem cells derived from bone marrow, adipose, and dermal tissue. Stem Cells Dev. 2012; 21:2189.

105. Chen YT, Sun CK, Lin YC, Chang LT, Chen YL, Tsai TH, Chung SY, Chua S, Kao YH, Yen CH, Shao PL, Chang KC, Leu S, Yip HK. Adipose-derived mesenchymal stem cell protects kidneys against ischemia-reperfusion injury through suppressing oxidative stress and inflammatory reaction. J Transl Med. 2011 May 5; 9:51.

106. Donizetti-Oliveira C, Semedo P, Burgos-Silva $\quad M$, Cenedeze MA, Malheiros DM, Reis MA, Pacheco-Silva A, Câmara NO. Adipose tissue-derived stem cell treatment prevents renal disease progression. Cell Transplant. 2012;21(8):1727-41.

107. Kim JH, Park DJ, Yun JC, Jung MH, Yeo HD, Kim HJ, Kim DW, Yang JI, Lee GW, Jeong SH, Roh GS, Chang SH. Human adipose tissuederived mesenchymal stem cells protect kidneys from cisplatin nephrotoxicity in rats. Am J Physiol Renal Physiol. 2012 May 1;302(9):F1141-50.

108. Katsuno T, Ozaki T, Saka Y, Furuhashi K, Kim H, Yasuda K, Yamamoto T, Sato W, Tsuboi N, Mizuno M, Ito Y, Imai E, Matsuo S, Maruyama S. 
Low serum cultured adipose tissue-derived stromal cells ameliorate acute kidney injury in rats. Cell Transplant. 2013;22(2):287-97.

109. Eirin A, Zhu XY, Krier JD, Tang H, Jordan KL, Grande JP, Lerman A, Textor SC, Lerman LO. Adipose tissue-derived mesenchymal stem cells improve revascularization outcome restore renal function in swine atherosclerotic renal artery stenosis. Stem Cells. 2012 May;30(5):103041.

110.Zhu XY, Urbieta-Caceres V, Krier JD, Textor SC, Lerman A, Lerman LO. Mesenchymal stem cells and endothelial progenitor cells decrease renal injury in experimental swine renal artery stenosis through different mechanisms.Stem Cells. 2013 Jan; 31(1):117-25.

111. Ebrahimi $\quad B$, Eirin $\quad A$, Li $\quad$ Z, Zhu XY, Zhang $\quad X$, Lerman $\quad A$, Textor SC, Lerman LO. Mesenchymal stem cells improve medullary inflammation and fibrosis after revascularization of swine atherosclerotic renal artery stenosis. PLoS One. 2013 Jul 3; 8(7): e67474.

112. Furuhashi K, Tsuboi N, Shimizu A, Katsuno T, Kim H, Saka Y, Ozaki T, Sado Y, Imai E, Matsuo S, Maruyama S. Serum-starved adiposederived stromal cells ameliorate crescentic $\mathrm{GN}$ by promoting immunoregulatory macrophages. J Am SocNephrol. 2013 Mar; 24(4):587603.

113. Deans RJ, Moseley AB. Mesenchymal stem cells: biology and potential clinical uses, Exp Hematol 2000; 28:875-884.

114. Di Nicola M, Carlo-Stella C, Magni M, Milanesi M, Longoni PD, suppress T-lymphocyte proliferation induced by cellular or nonspecific mitogenic stimuli. Blood 2002;99:3838-3843.

115. Aggarwal S, Pittenger MF. Human mesenchymal stem cells modulate allogeneicimmune cell responses. Blood, 2005; 105:1815-1822.

116. Rasmusson I. Immune modulation by mesenchymal stem cells. Exp Cell Res 2006;312:2169-2179.

117. Uccelli A, Pistoia V, Moretta L. Mesenchymal stem cells: a new strategy for immunosuppression? Trends in Immunol, 2007;28: 219-226.

118. Bartholomew A, Sturgeon C, Siatskas M, et al. Mesenchymal stem cells suppresslymphocyte proliferation in vitro and prolong skin graft survival in vivo. Exp Hematol; 2002; 30:42-48.

119. Ghannam S, Pene J, Torcy-Moquet G, et al. Mesenchymal stem cells inhibit humanTh17 cell differentiation and function and induce a T regulatory cell phenotype. J.Immunol, 2010; 185:302-312. 
120. Nauta AJ, Kruisselbrink AB, Lurvink E, et al. Mesenchymal stem cells inhibit generation and function of both CD34p-derived and monocytederived dendritic cells. Jlmmunol. 2006; 177:2080-2087.

121.Djouad F, Charbonnier LM, Bouffi C, et al. Mesenchymal stem cells inhibit the differentiation of dendritic cells through an interleukin-6dependent mechanism. StemCells, 2007; 25:2025-2032.

122. English K, Barry FP, Mahon BP. Murine mesenchymal stem cells suppress dendritic cell migration, maturation and antigen presentation. ImmunolLett; 2008; 115:50-58.

123. Chiesa S, Morbelli S, Morando S, et al. Mesenchymal stem cells impair in vivo T-cellpriming by dendritic cells. Proc Natl Acad Sci U S A; 2011; 108:17384-17389.

124. Rasmusson I, Ringdén O, Sundberg B, Le Blanc K. Mesenchymal stem cells inhibit the formation of cytotoxic $T$ lymphocytes, but not activated cytotoxic $T$ lymphocytes or natural killer cells. Transplantation 2003;76:1208-1213.

125. Nauta AJ, Fibbe WE. Immunomodulatory properties of mesenchymal stromal cells. Blood 2007; 110: 3499-506

126.Ren, G., Zhang, L., Zhao, X., et al. Mesenchymal stem cell-mediated immunosuppression occurs via concertedaction of chemokines and nitric oxide. Cell Stem Cell, 2008; 2(2), 141-150.

127.Zheng L, Ge H, Qiu L, Shu Q, Xu J. Mesenchymal Stromal Cells Affect disease results through the polarization macrophages. Célulastronco Int. 2015; 2015: 989473.

128. Sakaguchi S, Sakaguchi N, Asano M, Itoh M, Toda M. Immunologic selftolerance maintained by activated $T$ cells expressing IL-2 receptor alphachains (CD25). Breakdown of a single mechanism of self-tolerance causes various autoimune diseases. J Immunol. 1995 Aug 1;155(3):1151-64.

129. Piccirillo CA, Shevach EM. Cutting edge: control of CD8+ T cell activation byCD4+CD25+ immunoregulatory cells. J Immunol. 2001 Aug $1 ; 167(3): 1137-40$.

130. Fontenot JD, Gavin MA, Rudensky AY. Foxp3 programs the development and function of CD4+CD25+ regulatory T cells. Nat Immunol. 2003 Apr;4(4):330-6.

131. Li S, Weidenfeld J, Morrisey EE. Transcriptional and DNA binding activity of the Foxp1/2/4 family is modulated by heterotypic and homotypic protein interactions. Mol Cell Biol. 2004 Jan;24(2):809-22. 
132. Setoguchi R, Hori S, Takahashi T, Sakaguchi S. Homeostatic maintenance of natural Foxp3(+) CD25(+) CD4(+) regulatory $\mathrm{T}$ cells by interleukin (IL)-2 and induction of autoimmune disease by IL-2 neutralization. J Exp Med. 2005 Mar 7;201(5):723-35.

133. Bayer AL, Yu A, Malek TR. Function of the IL-2R for thymic and peripheral CD4+CD25+ Foxp3+ T regulatory cells. J Immunol. 2007 Apr $1 ; 178(7): 4062-71$.

134. Kingsley Cl, Karim M, Bushell AR, Wood KJ. CD25+CD4+ regulatory T cells prevent graft rejection: CTLA-4- and IL-10-dependent immunoregulation of alloresponses. J Immunol. 2002 Feb 1;168(3):10806.

135. Read S, Greenwald R, Izcue A, Robinson N, Mandelbrot D, Francisco L, et al. Blockade of CTLA-4 on CD4+CD25+ regulatory T cells abrogates their function in vivo. J Immunol. 2006 Oct 1;177(7):4376-83.

136. You S, Leforban B, Garcia C, Bach JF, Bluestone JA, Chatenoud L. Adaptive TGFbeta- dependent regulatory $T$ cells control autoimmune diabetes and are a privileged target of anti-CD3 antibody treatment. Proc Natl Acad Sci U S A. 2007 Apr 10;104(15):6335-40.

137. Sharma MD, Baban B, Chandler P, Hou DY, Singh N, Yagita H, et al. Plasmacytoid dendritic cells from mouse tumor-draining lymph nodes directly activate mature Tregs via indoleamine 2,3-dioxygenase. J Clin Invest. 2007 Sep;117(9):2570-82.

138. Corcione A, Benvenuto F, Ferretti E, Giunti D, Cappiello V, Cazzanti F, Risso M, Gualandi F, Mancardi GL, Pistoia V, Uccelli A. Human mesenchymal stem cells modulate B-cell functions. Blood. 2006;107(1):367-72.

139. Rasmusson I, Le Blanc K, Sundberg B, Ringdén O.Mesenchymal stem cells stimulate antibody secretion in human B cells. Scand $J$ Immunol. 2007 Apr;65(4):336-43.

140.Spaggiari GM1, Capobianco A, Becchetti S, Mingari MC, Moretta L.Mesenchymal stem cell-natural killer cell interactions: evidence that activated NK cells are capable of killing MSCs, whereas MSCs can inhibit IL-2-induced NK-cell proliferation. Blood. 2006 Feb 15;107(4):1484-90. Epub 2005 Oct 20.

141. English K, Barry FP, Mahon BP. Murine mesenchymal stem cells suppress dendritic cell migration, maturation and antigen presentation. ImmunolLett; 2008; 115:50-58. 
142. Gur-Wahnon D1, Borovsky Z, Beyth S, Liebergall M, Rachmilewitz J. Contact-dependent induction of regulatory antigen-presenting cells by human mesenchymal stem cells is mediated via STAT3 signaling. Exp Hematol. 2007 Mar;35(3):426-33.

143. Steinman RM, Nussenzweig MC. Avoiding horror autotoxicus: the importance of dendritic cells in peripheral $\mathrm{T}$ cell tolerance. ProcNatIAcadSci U S A. 2002; 8; 99(1):351-8.

144. Mills $\mathrm{KH}$, McGuirk P. Antigen-specific regulatory $\mathrm{T}$ cells--their induction and role in infection. SeminImmunol. 2004 Apr; 16(2):107-17.

145. Jiang XX, Zhang Y, Liu B, Zhang SX, Wu Y, Yu XD, Mao N. Human mesenchymal stem cells inhibit differentiation and function of monocytederived dendritic cells. Blood. 2005 May 15;105(10):4120-6.

146. Maccario R, Podestà $\quad M$, Moretta A, Cometa $A$, Comoli P, Montagna D, Daudt L, Ibatici A, Piaggio G, Pozzi S, Frassoni $F$, Locatelli F. Interaction of human mesenchymal stem cells with cells involved in alloantigen-specific immune response favors the differentiation of CD4+ T-cell subsets expressing a regulatory/suppressive phenotype.Haematologica. 2005 Apr;90(4):516-25.

147. Gonzalez-Rey E, Anderson P, Gonzalez MA, Rico L, Buscher D, Delgado M. Human adult stem cells derived from adipose tissue protect against experimental colitis and sepsis. Gut. 2009;58:929-939.

148. Ullman E. Tissue And Organ Transplantation. Ann Surg. 1914 Aug;60(2):195-219.

149. Fisher B, Lee S. Microvascular surgical techniques in research, with special reference to renal transplantation in the rat. Surgery, 1965; 58, $904 \pm 14$.

150.Lee S. An improved technique of renal transplantation in the rat. Surgery. 1967;61(5):771-773.

151. Naper C., Rolstad B., Wonigeit K. Butcher G. W and. Vaage J. T. Genes in two $\mathrm{MHC}$ class I regions control recognition of a single rat $\mathrm{NK}$ cell allodeterminant. International Immunology, 1996 Vol. 8, No. 11, pp. 17791785

152. Weissert, R., Wallstrom, E., Storch, M. K., Stefferl, A., Lorentzen, J., Lassmann, H., Linington, C., and Olsson, T. (1998). MHC haplotypedependent regulation of MOG-induced EAE in rats. J Clinlnvest 102, 12651273. 
153. Günther E., Walter L. The major histocompatibility complex of the rat (Rattus norvegicus). Immunogenetics. 2001, 53:520-542.

154. Grau V, Fuchs-Moll G, Wilker S, Weimer R, Padberg W. Proliferation of CD8-positive $T$ cells in blood vessels of rat renal allografts. Am J Transplant. 2011;11(9):1979-1985.

155. White EHW, Mullen Y. Chronic kidney allograft reactions in rats. Transplantation. 1969;8(5):602-617

156. Marco M L.The Fischer-Lewis model of chronic allograft rejection-a summary. Nephrology Dialysis Transplantation, Volume 21, Issue 11, 1 November 2006, Pages 3082-3086

157. Religa P, Bojakowski K, Bojakowska M, Gaciong Z, Thyberg J, Hedin U. Allogenic immune response promotes the accumulation of host-derived smooth muscle cells in transplant arteriosclerosis. Cardiovasc Res. 2005 Feb 1;65(2):535-45.

158. Bedi DS, Riella LV, Tullius SG, Chandraker A. Animal models of chronic allograft injury: contributions and limitations to understanding the mechanism of long-term graft dysfunction. Transplantation. 2010 Nov 15;90(9):935-44

159. Paul LC, Muralidharan J, Muzaffar SA, et al. Antibodies against mesangial cells and their secretory products in chronic renal allograft rejection in the rat. Am J Pathol. 1998;152(5):1209-1223.

160. Daniller A, Buchholz R, Chase RA. Renal transplantation in rats with the use of microsurgical techniques: a new method. Surgery. 1968;63(6):956961.

161. Spanjol J, Celić T, Jakljević T, Ivancić A, Markić D. Surgical technique in the rat model of kidney transplantation. CollAntropol. 2011 Sep;35 Suppl 2:87-90.

162. Estes BT et. al., Isolation of adipose-derived stem cells and their induction to a chondrogenic phenotype. Nat Protoc 5(7):1294 - 1311.

163. Shrestha B, Haylor J. Review of Surgical Techniques of Experimental Renal Transplantation in Rats. Experimental and Clinical Transplantation (2017) 4: 373-380

164. Martins P. N. A., Filatenkov A. Microsurgical techniques for experimental kidney transplantation and general guidelines to establish studies about transplantation immunology. Acta Cirúrgica Brasileira - Vol 18 (4) 2003 
165. Shrestha B, John Haylor.Experimental rat models of chronic allograft nephropathy: a review. International Journal of Nephrology and Renovascular Disease 2014:7

166. Franquesa M, Herrero E, Torras J, et al. Mesenchymal stem cell therapy prevents interstitial fibrosis and tubular atrophy in a rat kidney allograft model. Stem Cells Dev 2012; 21:3125-3135.

167. Kinomura M, Kitamura S, Tanabe K, Ichinose K, Hirokoshi K, Takazawa Y, Kitayama H, Nasu T, Sugiyama H, Yamasaki Y, Sugaya T, Maeshima Y, Makino H. Amelioration of cisplatin-induced acute renal injury by renal progenitor-like cells derived from the adult rat kidney. Cell Transplant. 2008;17:143-58.

168. Cavaglieri RC, Martini D, Sogayar MC, Noronha IL. Mesenchymal stem cells delivered at the subcapsule of the kidney ameliorate renal disease in the rat remnant kidney model. Transplant Proc 2009; 41:947-51.

169. Herrera MB, Bruno S, Buttiglieri S, Tetta C, Gatti S, Deregibus MC, Bussolati B, Camussi G. Isolation and characterization of a stem cell population from adult human liver. Stem Cells 2006a; 24:2840-50.

170.de Oliveira L. F., Almeida T. R., Machado M. P. R., et al. Priming mesenchymal stem cells with endothelial growth medium boosts stem cell therapy for systemic arterial hypertension. Stem Cells International. 2015;2015:12

171.Saad Ahmed, Allan B. Dietz, Sandra M.S. Herrmann, LaTonya J. Hickson, James F. Glockner, Michael A. McKusick, Sanjay Misra, Haraldur Bjarnason, Adam S. Armstrong, Dennis A. Gastineau, Lilach O. Lerman and Stephen C. Textor. Autologous Mesenchymal Stem Cells Increase Cortical Perfusion in Renovascular Disease. J Am Soc Nephrol 28: cccccc, 2017

172.van Koppen A, Joles JA, van Balkom BW, Lim SK, de Kleijn D, Giles RH, Verhaar MC. Human embryonic mesenchymal stem cell-derived conditioned medium rescues kidney function in rats with established chronic kidney disease. PLoS One. 2012;7(6):e38746.

173. Sedrakyan S, Da Sacco S, Milanesi A, Shiri L, Petrosyan A, Varimezova R, Warburton D, Lemley KV, De Filippo RE, Perin L. Injection of amniotic fluid stem cells delays progression of renal fibrosis. J Am Soc Nephrol. 2012; 23(4):661-73.

174. Santana AC1, Dellê H, Cavaglieri RC, Lopes MA, Francisco RP, Zugaib M, Bydlowski SP, Noronha IL. Protective effects of human amniotic fluid stem cells in a model of aorta allograft vasculopathy in rats. Transplant Proc. 2012 Oct;44(8):2490-4. 
175. Eirin A, Zhu XY, Krier JD, Tang H, Jordan KL, Grande JP, Lerman A, Textor SC, Lerman LO. Adipose tissue-derived mesenchymal stem cells improve revascularization outcomes to restore renal function in swine atherosclerotic renal artery stenosis. Stem Cells. 2012;30:1030-1041.

176. Kunter U, Song Rong, Peter Boor, Frank Eitner, Gerhard MüllerNewen,Zivka Djuric, Claudia R. van Roeyen, Andrzej Konieczny, Tammo Ostendorf,Luigi Villa, Maja Milovanceva-Popovska, Dontscho Kerjaschki§ and Jürgen FloegeMesenchymal Stem Cells Prevent Progressive Experimental Renal Failure but Maldifferentiate into Glomerular Adipocytes

177. Schrijvers Bieke F., Allan Flyvbjerg, An S.De Vriese. The role of vascular endothelial growth factor (VEGF) in renal pathophysiology. Volume 65, Issue 6, June 2004, Pages 2003-2017

178. Imberti B, Morigi M, Tomasoni S, Rota C, Corna D, Longaretti L, Rottoli D, Valsecchi F, Benigni A, Wang J, Abbate M, Zoja C, Remuzzi G. Insulinlike growth factor- 1 sustains stem cell mediated renal repair. J Am Soc Nephrol. 2007;18:2921-2928.

179. Oliveira-Sales EB, Varela VA, Maquigussa E, Borges FT, Shimoura CG, Gomes G, Campos RR, Boim MA.Renovascular hypertension: Effects of mesenchymal stem cells in the contralateral hypertensive kidney in rats. Clin Exp Hypertens. 2016;38(7):586-593

180. Wang S1, Li Y, Zhao J, Zhang J, Huang Y.Mesenchymal stem cells ameliorate podocyte injury and proteinuria in a type 1 diabetic nephropathy rat model. Biol Blood Marrow Transplant. 2013 Apr;19(4):538-46

181. Rookmaaker MB1, Smits AM, Tolboom H, Van 't Wout K, Martens AC, Goldschmeding R, Joles JA, Van Zonneveld AJ, Gröne HJ, Rabelink TJ, Verhaar MC. Bone-marrow-derived cells contribute to glomerular endothelial repair in experimental glomerulonephritis. Am J Pathol. 2003 Aug;163(2):55362 .

182. Cóndor JM, Rodrigues CE, Sousa Moreira Rd, Canale D2, Volpini RA, Shimizu MH, Camara NO, Noronha Ide L, Andrade L. Treatment With Human Wharton's Jelly-Derived Mesenchymal Stem Cells Attenuates Sepsis-Induced Kidney Injury, Liver Injury, and Endothelial Dysfunction. Stem Cells Transl Med. 2016 Aug;5(8):1048-57.

183. Irene L Noronha, Rita C Cavaglieri, Felipe L Janz, Sergio A Duarte, Marco A B Lopes, Marcelo Zugaib, andSergio P Bydlowski. The potential use of stem cells derived from human amniotic fluid in renal diseasesKidney Int Suppl. 2011 Sep; 1(3): 77-82. 
184. Uccelli A, Moretta L, Pistoia V. Mesenchymal stem cells in health and disease. Nat. Rev. Immunol. 2008; 8: 726-36.

185. Nauta AJ, Fibbe WE. Immunomodulatory properties of mesenchymal stromal cells. Blood 2007; 110: 3499-506

186. Hematti, P. (2008). Role of mesenchymal stromal cells in solid organ transplantation. Transplantation Reviews, 22(4), 262-273

187. Stout RD, Jiang CC, Matta B, Tietzel I, Watkins SK, Suttles J. Macrophages sequentially change their functional phenotype in response to changes in microenvironmental influences. J. Immunol. 2005; 175: 342-9.

188. Ricardo SD, van Goor H, Eddy AA. Macrophage diversity in renal injury and repair. J. Clin. Invest. 2008; 118: 3522-30.

189. Hanson S. E., Jaehyup Kim; and Peiman Hematti. Comparative Analysis of Adipose-Derived Mesenchymal Stem Cells Isolated From Abdominal and Breast Tissue. Aesthetic Surgery Journal 2013. 33(6) 888-898

190. Kim J, Hematti P. Mesenchymal stem cell-educated macrophages: A novel type of alternatively activated macrophages. Exp. Hematol. 2009; 37: 1445-53.

191. Maggini J, Mirkin G, Bognanni I et al. Mouse bone marrow-derived mesenchymal stromal cells turn activated macrophages into a regulatory-like profile. PLoS ONE 2010; 5: e9252.

192. Nemeth K, Leelahavanichkul A, Yuen PST et al. Bone marrow stromal cells attenuate sepsis via prostaglandin E-2-dependent reprogramming of host macrophages to increase their interleukin-10 production. Nat. Med. 2009; 15: 429.

193.Zhang QZ, Su WR, Shi SH et al. Human gingiva-derived mesenchymal stem cells elicit polarization of M2 macrophages and enhance cutaneous wound healing. Stem Cells 2010; 28: 1856-68.

194. Di Nicola M, Carlo-Stella C, Magni M, et al. Human bone marrow stromal cell ssuppress T-lymphocyte proliferation induced by cellular or nonspecific mitogenic stimuli.Blood;2002; 99:3838-3843.

195.Le Blanc K, Pittenger M. Mesenchymal stem cells: progress toward promise.Cytotherapy. 2005;7(1):36-45.

196.Luz-Crawford P, Kurte $\quad$ M, Bravo-Alegría $\quad J$, Contreras $\quad$ R, Nova-Lamperti E, Tejedor G, Noël D, Jorgensen C, Figueroa F, Djouad F, Carrión F. Mesenchymal stem cells generate a CD4+CD25+Foxp3+ regulatory $\mathrm{T}$ cell population during the differentiation process of Th1 and Th17 cells. Stem Cell Res Ther. 2013 Jun 4;4(3):65. 
197. Uccelli A, Moretta L, Pistoia V. Mesenchymal stem cells in health and disease. Nat Rev Immunol. 2008;8(9):726-36.

198. Le Blanc K, Ringdén O. Immunomodulation by mesenchymal stem cells and clinical experience. J Intern Med. 2007;262(5):509-25.

199. Wang Y., F. Lian, J. Li et al., "Adipose derived mesenchymal stem cells transplantation via portal vein improves microcirculation and ameliorates liver fibrosis induced by $\mathrm{CCl} 4$ in rats," Journal of Translational Medicine, vol. 10, no. 1, article 133, 2012.

200.Ebrahimi B., A. Eirin, Z. Li et al., "Mesenchymal stem cells improve medullary inflammation and fibrosis after revascularization of swine atherosclerotic renal artery stenosis," PLoS ONE, vol. 8, no. 7, Article ID e67474, 2013.

201. Moodley Y., D. Atienza, U. Manuelpillai et al., "Human umbilical cord mesenchymal stem cells reduce fibrosis of bleomycin-induced lung injury," American Journal of Pathology, vol. 175, no. 1, pp. 303-313, 2009.

202. M. Mihara, Y. Moriya, and Y. Ohsugi, "IL-6-soluble IL-6 receptor complex inhibits the proliferation of dermal fibroblasts," International Journal of Immunopharmacology, vol. 18, no. 1, pp. 89-94, 1996.

203. Irwin C. R., T. T. Myrillas, P. Traynor, N. Leadbetter, and T. E. Cawston, "The role of soluble interleukin (IL)- 6 receptors in mediating the effects of IL-6 on matrix metalloproteinase-1 and tissue inhibitor of metalloproteinase-1 expression by gingival fibroblasts," Journal of Periodontology, vol. 73, no. 7, pp. 741-747, 2002.

204. H. Nakahara, J. Song, M. Sugimoto et al., "Anti-interleukin-6 receptor antibody therapy reduces vascular endothelial growth factor production in rheumatoid arthritis," Arthritis and Rheumatism, vol. 48, no. 6, pp. 15211529, 2003.

205. Sullivan DE, Ferris M, Pociask D, Brody AR. Tumor necrosis factor- $\alpha$ induces transforming growth factor-1 expression in lung fibroblasts through the extracellular signal-regulated kinase pathway. Am J Respir Cell Mol Biol 2005;32:342-9.

206. Kahari V.M. , H. Larjava, J. Uitto. Differential regulation of extracellular matrix proteoglycan. (PG) gene expression Transforming growth factorbeta 1 up-regulates biglycan. (PGI) and versican. (large fibroblast PG) but down-regulates decorin. (PGII) mRNA levels in human fibroblasts in cultureJ. Biol. Chem., 266 (1991), pp. 10608-10615 
207. Furuichi K, Shintani H, Sakai Y, Ochiya T, Matsushima K, Kaneko S, Wada T. Effects of adipose-derived mesenchymal cells on ischemiareperfusion injury in kidney. Clin Exp Nephrol. 2012;16:679-689. doi: 10.1007/s10157-012-0614-6.

208.Dror S. Shouval, Jodie Ouahed, Amlan Biswas, Jeremy A. Goettel, Bruce H. Horwitz\|, Christoph Klein, Aleixo M. Muise, , Scott B. Snapper* Chapter Five - Interleukin 10 Receptor Signaling: Master Regulator of Intestinal Mucosal Homeostasis in Mice and Humans. Advances in Immunology. Volume 122, 2014, Pages 177-210 